Portland State University

PDXScholar

1987

\title{
Geomorphic character, age and distribution of rock glaciers in the Olympic Mountains, Washington
}

Steven Paul Welter

Portland State University

Follow this and additional works at: https://pdxscholar.library.pdx.edu/open_access_etds

Part of the Geology Commons, and the Geomorphology Commons Let us know how access to this document benefits you.

\section{Recommended Citation}

Welter, Steven Paul, "Geomorphic character, age and distribution of rock glaciers in the Olympic Mountains, Washington" (1987). Dissertations and Theses. Paper 3558.

https://doi.org/10.15760/etd.5440

This Thesis is brought to you for free and open access. It has been accepted for inclusion in Dissertations and Theses by an authorized administrator of PDXScholar. Please contact us if we can make this document more accessible: pdxscholar@pdx.edu. 
AN ABSTRACT OF THE THESIS OF Steven Paul Welter for the Master of Science in Geography presented August 7, 1987.

Title: The Geomorphic Character, Age, and Distribution of Rock Glaciers in the 01ympic Mountains, Washington

APPROVED BY MEMBERS OF THE THESIS COMMITTEE:

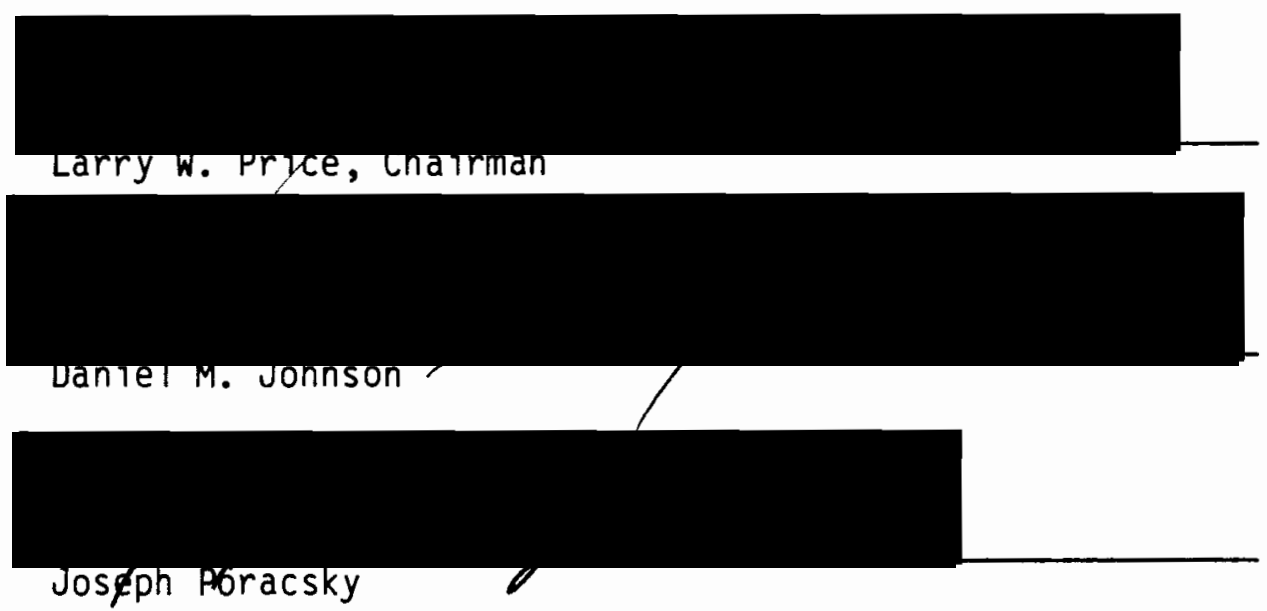

Rock glaciers are tongue-shaped or lobate masses of rock debris which occur below cliffs and talus in many alpine regions. They are best developed in continental alpine climates where it is cold enough to preserve a core or matrix of ice within the rock mass but insufficiently snowy to produce true glaciers. Previous reports have identified and briefly described several rock glaciers in the $01 y$ mpic Mountains, Washington (Long 1975a, pp. 39-41; Nebert 1984), but no detailed integrative study has been made regarding the geomorphic character, age, 
and distribution of these features.

The purpose of this study is two-fold. First, surface sediment fabric analysis and relative and absolute dating methods are used to determine the geomorphic character and age of Akela rock glacier. Secondly, the distribution of rock glaciers in the northeast $01 y m p i c s$ is analyzed in terms of topoclimatic and geologic factors in order to understand the environmental conditions under which they formed. In addition, the distribution of rock glaciers is compared to that of past and present glaciers.

Radiocarbon dates indicate that Akela rock glacier formed with in the past 10,000 years, most likely about 3,000 to 5,000 years ago. The rock glacier has clearly not been active for at least 200 to 300 years. Relative age data indicate that the surface of the rock glacier is variably-aged; boulders at the head of the rock glacier have been most recently deposited and have been least influenced by rock glacier flow. In contrast, boulders at the rock glacier toe display signs of being inactive for many years. Boulders at the rock glacier toe and upper lobe face display a preferred orientation, which is attributed to past rock glacier activity. The lateral ridges of the rock glacier were the first areas to stabilize, probably more than 1000 years ago. In addition to a warming climate, the lack of a continued supply of debris from the headwall above Akela rock glacier was a factor in its becoming inactive. These results indicate that both fabric analys is and relative dating methods can be used to better understand the geomorphic character and age of rock glaciers.

Rock glaciers in the Olympic Mountains occur entirely with in the 
more continental northeastern section of the 01 ympics. With in this area, they are preferentially located to the lee of the Needles Ridge and Mt. Constance Massif, where precipitation is most 1 imited. These rock glaciers may be composed of either sandstones or basalts, but are restricted to areas where their debris supply is coarse and blocky. The surface character of the eight rock glaciers surveyed suggests that at least seven of them are inactive.

The rock glaciers occupy an elevational zone distinct from present or past glaciers as a result of their formation in areas of limited snow accumulation. Also, their downslope elevation may be restrained by lack of debris from the cliffs above them. The mean rock glacier toe elevation of about $1700 \mathrm{~m}$ suggests an approximate lower limit for discontinuous Neoglacial permafrost. 
GEOMORPHIC CHARACTER, AGE AND DISTRIBUTION OF ROCK GLACIERS

IN THE OLYMPIC MOUNTAINS, WASHINGTON

by

STEVEN PAUL WELTER

A thesis submitted in partial fulfillment of the requirements for the degree of

MASTER OF SCIENCE

in

GEOGRAPHY

Portland State University 
TO THE OFFICE OF GRADUATE STUDIES AND RESEARCH:

The members of the Committee approve the thes is of Steven Paul Welter presented August 7, 1987.

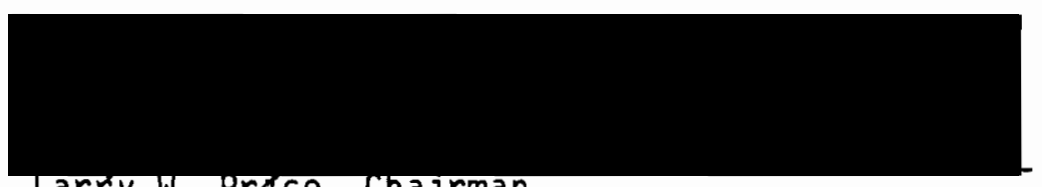

Larry w. Proce, chairman
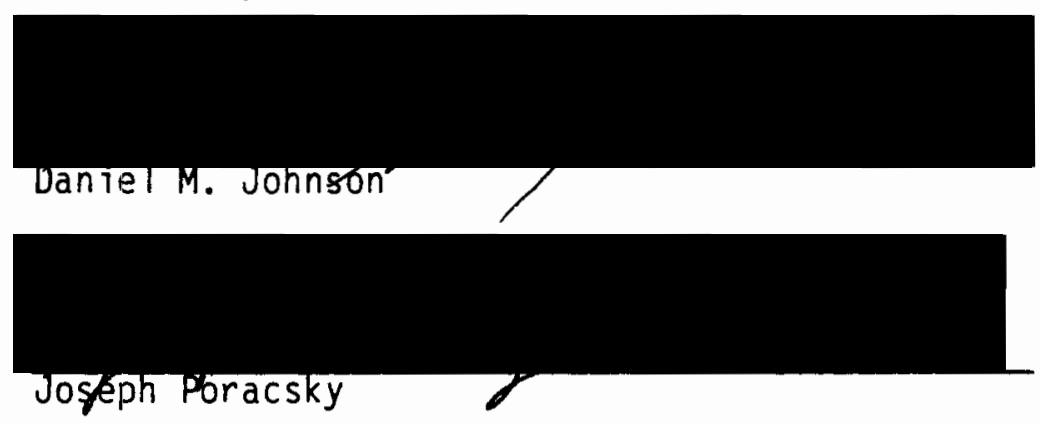

APPROVED:
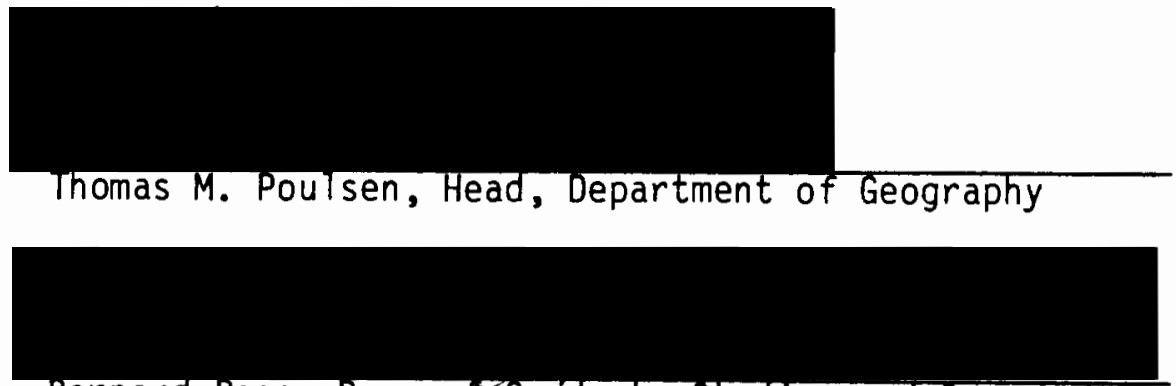

Bernard Ross, Dean of Graduate Studies and Research 


\section{ACKNOWLEDGEMENTS}

I wish to thank those people who helped make this thes is possible. Many thanks to Larry Price, who encouraged and advised me from the beginning to the end of this project and shared his knowledge of mountains with me.

Very special thanks to Leslie Anderson, who helped with all phases of the thesis, including fieldwork, editing, and particularly the graphics. I warmly appreciate the support and companionship that she provided.

I would also like to thank all the faculty, staff, and fellow students in the Geography Department at Portland State for providing a friendly learning environment and for helping whenever help was needed. 
TABLE OF CONTENTS

PAGE

ACKNOWLEDGEMENTS ........................... i

LIST OF TABLES ............................. vi

LIST OF FIGURES ................................. vii

CHAPTER

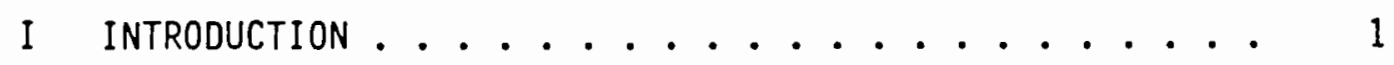

Purpose ................ . . 4

II LiteratURE REVIEW ..................... 6

Early Investigations ........... 8

Ice-Cored and Ice-Cemented Rock Glaciers..... 9

Inactive Rock Glaciers.......... 14

Distributional Controls .......... 15

Geologic Controls

Climatic Controls

Rock Glacier Studies in the Pacific Northwest . . 18

III AREAL SETTING ................. 20

Physical Setting of the $01 y$ mpic Mountains ... . 20

Physiography and Geology

Climate

Glaciation

Vegetation

Soils

Study Site Description . . . . . . . . .

Gray Wolf Ridge

Akela Rock Glacier

Cirque Headwa 11 and Talus 
CHAPTER

IV METHODOLOGY . . . . . . . . . . . . . . 42

V DATA ANALYSIS ................... 45

Geomorphic Data . . . . . . . . . . 45

Size and Fabric Data

Talus Activity

Age Data................... 63

Tree Core Data

Lichen Data

Boulder Weathering

Soils Data

Meadow Stratigraphy

VI FORMATION AND AGE OF AKELA ROCK GLACIER . . . . . • 80

VII CHARACTER AND DISTRIBUTION OF ROCK GLACIERS IN THE

NORTHEAST OLYMPICS ................ 90

Form and Surface Character . . . . . . . 92

Form and Activity

Rock Type

Vegetation Cover

Distribution . . . . . . . . . . . 98

Location

Aspect and Elevation

Permafrost Implications

VIII SUMMARY AND CONCLUSIONS . . . . . . . . . . . . 106 REFERENCES CITED . . . . . . . . . . . . . . . . 110 APPENDIX . . . . . . . . . . . . . . . . . . . 118 


\section{LIST OF TABLES}

$\underline{T A B L E}$

PAGE

I Late Pleistocene glacial events in western Washington.

II Elevation, slope, and orientation data for boulder and talus sample sites at Akela rock glacier.....

II Long-axis length measurements for boulder sample sites on Akela rock glacier .........

IV Clast orientation for boulder and talus sample sites at Akela rock glacier ...........

$\checkmark$ Age of trees growing on Akela rock glacier determined from growth-ring counts ..........

VI Maximum thallus diameter and percentage coverage of Rhizocarpon for boulder sample sites at Akela rock glacier...............

VII Maximum Rhizocarpon diameters ( $\mathrm{mm}$ ) from selected areas in the western United States ........

VIII Corner angularity from boulder sites on Akela rock rock glacier............... 69

IX Soils data for Akela rock glacier and adjacent sites . 71

$x$ Principal stratigraphic names and correlation of Holocene glacial deposits in the Cascade and 01 ympic Mountains, Washington ........ 
XI Surface character, elevation, and aspect of rock glaciers in the northeast $01 y m p i c$ Mountains . . .

XII Hydrometer analysis data for soil site A on Akela rock glacier . . . . . . . . . . . . . 120

XIII Hydrometer analysis data for soil site $B$ on Akela rock glacier . . . . . . . . . . . . 121

XIV Hydrometer analysis data for soil site $C$ on Akela rock glacier . . . . . . . . . . . . . 122

XV Hydrometer analysis data for soil site D on Akela rock glacier . . . . . . . . . . . . 123

XVI Hydrometer analysis data for soil site $E$ on Akela rock glacier . . . . . . . . . . . . . . 124

XVII Hydrometer analysis data for soil site $F$ downvalley from Akela rock glacier . . . . . . . . . 125 XVIII Hydrometer analys is data for soil site G downvalley from Akela rock glacier . . . . . . . . . 126 


\section{LIST OF FIGURES}

FIGURE

1. Akela rock glacier in the northeast $01 y m p i c$ Mountains, Washington, displays ridge and furrow topography . . . 2

2. Classification of rock glaciers based upon origin of materials ................... 7

3. Location of the 0lympic Mountains on the 0lympic

Peninsula, Washington ............ 21

4. Major drajnages of the Olympic Mountains . . . . . . . 23

5. Geologic terranes of the Olympic Mountains . . . . . . . 24

6. Formation of the 01 ympic Mountains . . . . . . . . . 25

7. Annual precipitation ( $\left.\mathrm{mm} \mathrm{yr}^{-1}\right)$ of the $01 y \mathrm{mpic}$

Peninsula . . . . . . . . . . . . . 28

8. The northeast 0lympic Mountains and vicinity . . . . . . 34

9. Longitudinal profile of Akela rock glacier . . . . . . 37

10. A bouldery transverse furrow on the surface of Akela rock glacier .................. 39

11. A boulder pit on the upper surface of Akela rock glacier. 39

12. Locations of sampling sites on Akela rock glacier . . . 44

13. Long-axis orientation of 50 boulders from sample sites

on Akela rock glacier ........... 50

14. Long-axis orientation of 50 boulders from talus sample sites ...................... 
15. Long-axis dip of 50 boulders from sample sites on Akela rock glacier............... 5 54

16. Lower tarp site, 1978 ............. 57

17. Lower tarp site, 1985 . . . . . . . . . . 58

18. A large Rhizocarpon thallus on a boulder at the lower tarp site indicates a long period of talus stability. 60

19. Middle tarp site, 1978 ............. 61

20. Middle tarp site, 1986 .............. 62

21. Soil profiles for Akela rock glacier and adjacent sites $\quad 72$

22. Soil profile at Site $E$ on Akela rock glacier illustrates a Spodosolic profile.............. 74

23. Stratigraphy of meadow.............. 77

24. Location of rock glaciers and glaciers, northeast 0lympic Mountains ................... 91

25. Sharp-angled front of Walkinshaw rock glacier, northeast 0lympic Mountains ...................... 95

26. Aspect and elevation of rock glaciers versus past and present glaciers, northeast 01 ympic Mountains ... . 101 


\section{CHAPTER I}

\section{INTRODUCTION}

Rock glaciers are common geomorphic features in many alpine regions. They are often described as "...tongue-shaped or lobate masses of poorly sorted angular debris lying at the base of cliffs or talus slopes..." (Wahrhaftig and Cox 1959, p. 387). Rock glaciers typically exhibit a complex surface topography, including transverse or longitudinal ridges and furrows, conical depressions, crevasses and lobes (Figure 1). The presence of a matrix or core of ice within the rock mass allows the rock glacier to move downslope in a flow-like manner. The conditions for rock glacier development are best met in continental alpine areas where frost $c$ limates and steep cliffs combine to produce an abundant source of rock debris. The investigation of rock glaciers as distinct phenomena was initiated near the turn of the century, but most of the literature on them has been published in the past 25 years.

Information derived from rock glacier research has been useful to geomorphologists in a variety of ways. Movement rates of rock glaciers can be used as mass wasting and erosional indices in alpine periglacial settings. Several research efforts have monitored rock glacier movement over periods of years (Wahrhaftig and Cox 1959; White 1971; Barsch 1977). By combining the measured rate of movement with the calculated volume of rock glacier debris, it is possible to determine the overall 


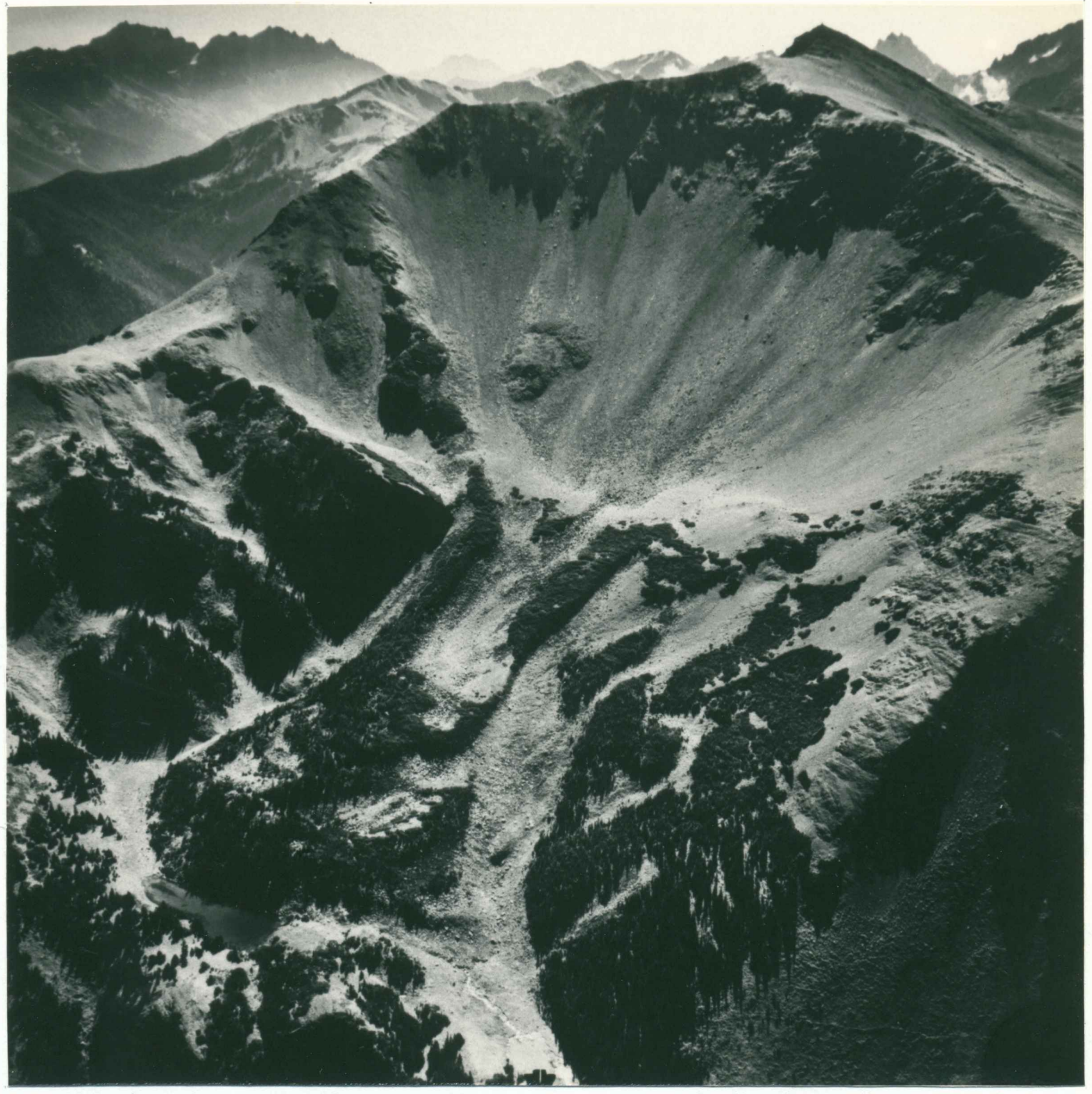

Figure 1. Akela rock glacier, northeast 01 ympic Mountains, Washington, displays ridge and furrow topography. The view is to the south. Photo by Austin Post, USGS. 
effectiveness of rock glaciers as alpine debris transport systems. Another function of rock glacier research has been to use their locational, elevational, and relative age characteristics aids in reconstructing past climates (Wahrhaftig and Cox 1959; Birkeland 1973; Luckman and Crockett 1978; Benedict 1981). It is generally understood that the climate must be cold enough to allow ice to persist within a rock glacier, but insufficiently snowy to maintain a true glacier. Therefore, rock glaciers are important climatic indicators because they form in periglacial environments and may be indicative of permafrost (White 1976, p. 78; Barsch 1977, p. 233).

Several rock glaciers have been identified in the 01 ympic Mountains, Washington (Long 1975a, pp. 39-41). These features, along with other geomorphic phenomena such as patterned ground and turf-banked terraces, suggest a formerly more rigorous climate (Hansen 1976, p. 73; Hansen-Bristow and Price 1985, p. 269). Although there have been scattered reports of rock glaciers in other mountains of the Pacific Northwest (Thompson 1962; Kiver 1974; Crandell and Mi1ler 1974), no detailed field studies of them have been made.

During the summer of 1983, I was a participant in the Mountain Geography Field Camp at Portland State University, and visited Akela rock glacier in the northeast 0lympic Mountains. The general lack of knowledge regarding the geomorphic character and significance of Akela and other rock glaciers in the 0lympics raised several questions in my mind which eventually evolved into the major questions of this research: Why do rock glaciers form in these locations instead of glaciers? What are the most significant environmental factors which control their 
distribution? What can the present morphology and surface character of the rock glaciers reveal about their present and past level of activity and formation processes? When did the rock glaciers form and, if they are no longer active, when did they cease movement?

\section{PURPOSE}

The purpose of this study is two-fold. First, it investigates the geomorphic character and age of the Akela rock glacier, the largest and best developed of such features in the 01 ympic Mountains. The limited amount of time available for field study and the difficult access to and between the rock glaciers prevented me from studying more than one rock glacier in detail. Although several rock glaciers were visited briefly, Akela was chosen as the site for detailed field analys is because of its proximity to a wet meadow which offered potential for uncovering organic material for radiocarbon dating, and also because it would be possible to utilize data collected by myself and other students studying the area during previous field camps.

Formation mechanisms and geomorphic activity of Akela rock glacier were examined through analys is of its surface character and morphology. Special emphas is was placed upon comparing and contrasting the size and arrangement of boulders at different locations on the rock glacier. This should allow determination of whether rock glacier flow can be attributed to the manner in which the surface sediments are distributed. The geomorphic relationship between Akela rock glacier and its source area was examined through an analys is of contemporary talus activity. The age of Akela rock glacier was determined through the use of 
relative age dating methods, including lichenometry, boulder weathering, and soil development. These techniques, in addition to tree core sampling are used to determine the age of stabilization of rock glacier surfaces. Again, multiple surface areas on the rock glacier were sampled in order to compare and contrast the age characteristics at various levels on the rock glacier. Radiocarbon dates obtained from organic material downvalley from the toe of the rock glacier are used to establish absolute limiting dates for rock glacier formation.

The second purpose of the research is to analyze rock glacier distribution in the northeast 01 ympic Mountains in terms of topoclimatic and geologic factors. Morphology and surface character are examined and distributional characteristics of rock glaciers are compared to past and present glacial distributions in order to assess the environmental factors most significant in producing rock glaciers in the $01 y m p i c$ Mountains. 
CHAPTER II

\section{LITERATURE REVIEW}

Definition, classification, and identification of rock glaciers is difficult because they are part of a continuum of gradational alpine mass movement features which may originate from a number of processes and materials (Figure 2). Several schemes have been proposed to differentiate rock glaciers from other landforms and to distinguish between different types of rock glaciers (Wahrhaftig and Cox 1959; J.P. Johnson 1973; Corte 1976; White 1976, 1981; Barsch 1977; P.G. Jo hnson 1983). At least 15 different terms have been used to describe forms which are now recognized as rock glaciers (White 1981, pp. 133-34).

The nature of rock glacier movement is not completely understood. A common explanation is that movement occurs because of slow deformational flow of ice wich occupies the interstices with in the blocky rock glacier debris (Wahrhaftig and Cox 1959, p. 401). Flow is initiated by gravitational forces in conjunction with the weight of overlying material. An alternative explanation is that rock glaciers are simply glaciers covered with a rock mantle; they flow due to the downslope deformation of the glacial ice (Potter 1972; Whalley 1974). A more recent proposal for rock glacier motion is that they move by basal slippage due to hydrostatic pressure of either pore water or groundwater trapped beneath the rock glacier (Haeberle et al. 1979, p. 434; Giardino 1983, p. 303). 


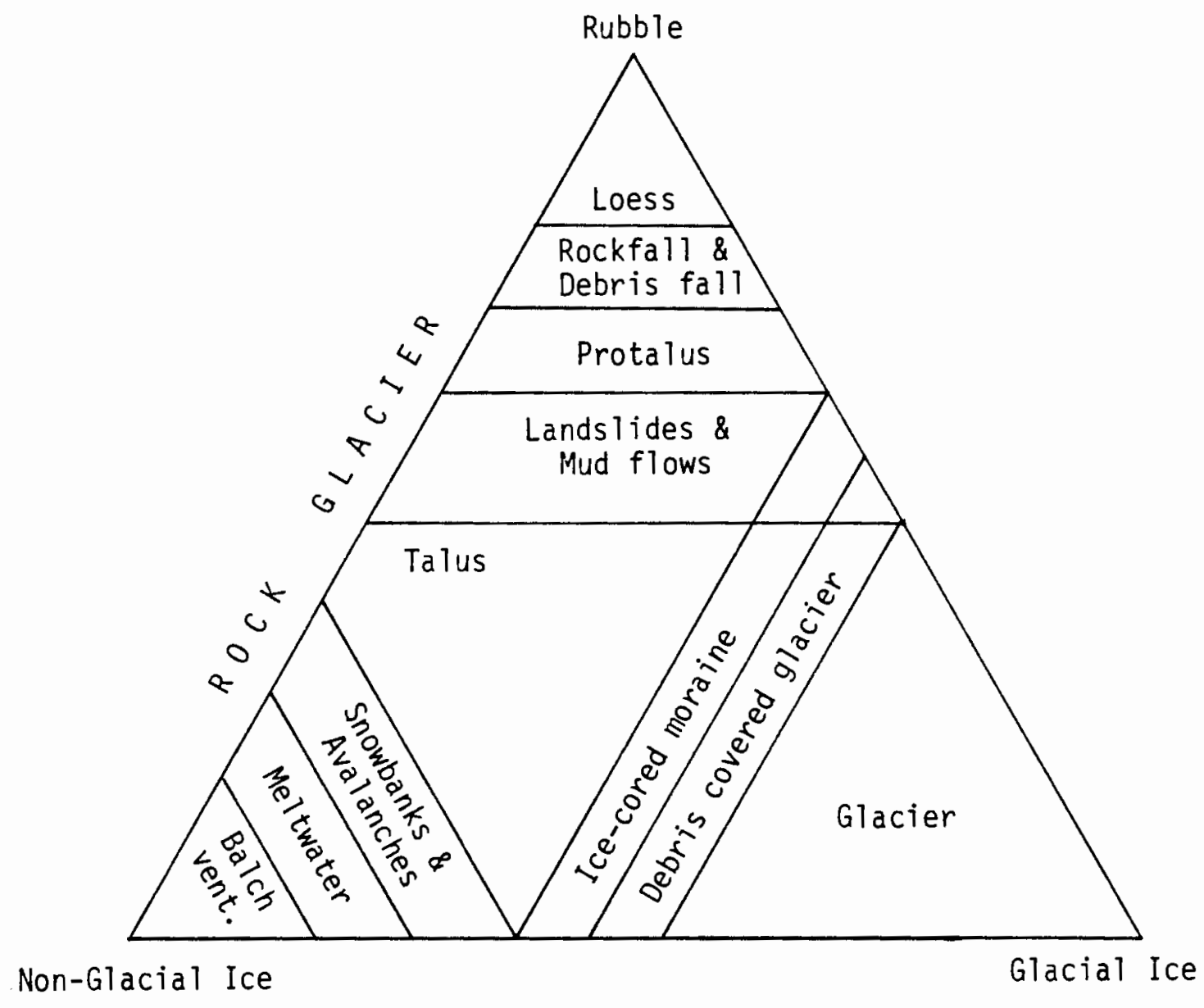

Figure 2. Classification of rock glaciers based upon origin of materials. Adapted from J.P. Johnson (1973). 
EARLY INVESTIGATIONS

The earliest known reference to rock glaciers in North America was presented by Spencer (1900), who briefly described a rock glacier in the San Juan Mountains, Colorado, as "a peculiar form of talus." Cross and Howe $(1905$, p. 25), also working in the San Juan Mountains, explained the development of "rock streams" as unusual moraines deposited across glaciers. Later, Howe $(1909$, p. 52) suggested that violent landslides were responsible for these forms.

Capps (1910, p. 364) introduced the term "rock glacier" in his survey of these features in the Wrangell Mountains, Alaska. He proposed that rock glaciers develop from the blocky debris in the terminal moraines left by melting glaciers. This debris becomes saturated with glacial meltwater, snowmelt, and rain, which freeze in the interstices of the blocky debris. Incipient flow is initiated by expansion of the water upon freezing, and motion is continued in a glacier-like movement long after the original glacier has melted. Recognizing a continuum between the glacial and rock glacial systems, Capps called rock glaciers "the true successors of real glaciers." He also reported excavating seven or eight rock glaciers and discovering "interstitial ice, filling the cavities between the angular fragments and forming, with the rock, a breccia with the ice as a matrix." Tyrell (1910, pp. 552-53) agreed with Capps regarding the function of interstitial ice and suggested that the ice might be derived from water issuing from springs. He also proposed that the concentric ridges on rock glaciers are the result of downslope movement of rocks during spring melt. Chaix (1923, in Potter 1972, p. 3026) thought rock glaciers were formed from terminal moraines 
which moved downslope because of freezing and thawing of interstitial mud and clay.

Brown (1925, pp. 464-65) reported "a probable fossil glacier" in the San Juan Mountains, Colorado. He described a mining tunnel dug laterally through a rock glacier which consisted of angular blocks cemented by an ice matrix for the initial 300 feet. Once past the ice-cemented debris, Brown encountered a central core of massive ice extending 100 feet to the rock wall. Brown thought the ice was probably of glacial origin and considered the rock glacier to have formed by debris sliding over a glacier, as was proposed by Cross and Howe (1905). Kesseli (1941, pp. 226-27), working in the Sierra Nevada, believed that rock glaciers represent small glaciers which were overloaded with debris from adjacent cliffs; the notion that they formed primarily by landslide or creep of interstitial ice was discarded.

\section{ICE-CORED AND ICE-CEMENTED ROCK GLACIERS}

In their classic study, Wahrhaftig and Cox (1959) surveyed 200 rock glaciers in the Alaska Range. They concluded that rock glaciers are primarily non-glacial in origin and develop and flow due to interstitial ice. They further concluded that while theoretically all gradations between glaciers and rock glaciers exist, in fact the unique climatic conditions necessary for the development and persistence of interstitial ice generally preclude the existence of intermediate or transitional stages between the two (Wahrhaftig and Cox 1959, p. 433).

The formation and persistence of interstitial ice may be attributed in part to the effect of Balch ventilation (Thompson 1962, p. 218). By 
this process, small crevices and interstices within the blocky debris of rock glaciers are preferentially cooled by cold air drainage during the winter, in the manner described by Balch (1897), for preservation of ice in caves.

In contrast to the interstitial ice theories, several researchers began to present evidence that some rock glaciers contain cores of glacial ice similar to the situations described by Brown (1925) and Kesseli (1941). A study in the Colorado Rockies described a rock glacier with a clean, exposed ice core and, in conjunction with evidence derived from air photo interpretation, concluded that "...rock glaciers beneath cirque head walls represent the debris-covered tongues of true glaciers that formerly occupied the floors of cirques" (Outcalt and Benedict 1965, pp. 851-52).

Rock glaciers are usually classified as being either tongue-shaped or lobate. Tongue-shaped rock glaciers have a downvalley length greater than width. This is contrasted to lobate rock glaciers, which flow away from valley walls and display widths which are greater than their lengths. Most tongue-shaped rock glaciers are found in cirques formerly occupied by glaciers. In many cases, tongue-shaped rock glaciers exist immediately below present-day small cirque glaciers. Barsch (1971, p. 205) attributed this relationship to the fact that small glaciers generally tend to terminate very near snowline. This means that at the terminal moraine of the glacier, conditions are often still cold enough for interstitial ice formation, particularly through Balch ventilation. On the other hand, transitional sequences between debris-laden glaciers, ice-cored moraines, and rock glaciers are well-documented (Lliboutry 
1953; Vernon and Hughes 1966; White 1971; Potter 1972; P.G. Johnson 1974). Under some circumstances, a glacier becomes covered with debris in its lower zone and merges with an ice-cored moraine, eventually becoming a rock glacier.

Some researchers now think that tongue-shaped rock glaciers are formed only from debris-laden glaciers. However, this assertion does not seem warranted in light of the discovery of these features in non-glaciated mountains. R.B. Johnson (1967, pp. 217-19) described a "rock stream" composed of interstitial ice in an unglaciated area of the Sangre de Cristo Mountains, Colorado. Studies by Blagbrough and Farkas (1968) in the San Mateo Mountains, New Mexico and by Barsch and Updike (1971) at Kendrick Peak, Arizona both described inactive rock glaciers occurring in areas never reached by glaciation. Their presence is undoubtedly a result of the formation of interstitial ice under formerly more severe climatic conditions.

Most researchers today accept the fact that rock glaciers may be either glacial or non-glacial in origin. However, there is still considerable disagreement over the importance of distinguishing between the two. According to Barsch (1977, p. 235), there are several reasons why this distinction is unnecessary: it is often too difficult to tell the two apart; other processes such as ice segregation in permafrost could be responsible for large bodies of massive ice within a rock glacier; a genetic explanation is not essential to an understanding of rock glaciers as mass-wasting phenomena; and if rate of movement is used as a criterion for discriminating origin, the similarities between ice-cored and ice-cemented rock glaciers are much greater than the 
similarities between ice-cored rock glaciers and true glaciers (i.e., the movement rates of both ice-cored and ice-cemented rock glaciers tend to be an order of magnitude less than most true glaciers).

Barsch's contentions may be warranted for determining mass-wasting or erosional rates, but seem to be less valid when applied to the use of rock glaciers as paleoclimatic indicators. One problem is that ice-cored rock glaciers may not actually represent a true permafrost zone in that the ice core is merely prevented from melting due to the insulating effect of the overriding debris. Potter (1972, p. 3054) estimates that a lag period of several thousand years may exist between the melting away of the clean ice portion of a debris-laden glacier and the remaining ice-cored interior of the rock glacier. Thus, an ice-cored rock glacier may not represent a permafrost environment, but simply a well-insulated glacial ice remnant.

Several distinguishing features of rock glaciers of glacial origin have been suggested (Vernon and Hughes 1966, pp. 17-22). These include: a saucer- or spoon-shaped depression in clean glacier ice between the base of the cirque headwall and the rock glacier; longitudinal furrows running along each side of the rock glacier upslope from the front; central meandering furrows; conical or coalescing steepsided collapse pits floored with ice and/or filled with water; absence of prominent transverse ridges and furrows; and visible massive ice underlying the debris cover. Recent surveys have considered these criteria to be fairly reliable (Luckman and Crockett 1978; White 1976). These studies suggest that distinguishing between the ice-cored and ice-cemented rock glacier types may be useful in understanding rock glacier distribution 
patterns.

White (1976, pp. 81-82) found that ice-cored rock glaciers in the northern Colorado Rockies were preferentially located on the eastern side of the Continental Divide, or east of high ridges in cirques facing downwind. West of the divide, the rock glaciers face into the wind (i.e., in a west to north direction) and are ice-cemented. White attributed the differences between the ice-cored and ice-cemented features on the east and west sides of the divide to exposure, direction of wind-drifted snow for production of glacial ice, and lastly to local microclimate. He found permafrost in and around the rock glaciers on both sides of the range. Despite the sparseness of data in the report, it is important to recognize that these features may occupy distinct and separate locations. Also, both types occur in permafrost areas and can therefore be said to indicate a permafrost environment.

A somewhat different distinction between ice-cored and ice-cemented types was observed in a survey of 119 rock glaciers in the Canadian Rockies (Luckman and Crockett 1978, p. 547). The "non-glacial" (ice-cemented) type averaged 60 to $70 \mathrm{~m}$ lower in elevation than the "glacial" (ice-cored) type. This was considered by the authors to represent a significant altitudinal zonation control associated primarily with mode of origin. An exact explanation of this statistically significant difference has yet to be proposed, but the implication is that ice-cemented rock glaciers occur under less severe climatic conditions. 
INACTIVE ROCK GLACIERS

Rock glaciers are considered to be inactive when they have ceased movement. They are most easily distinguished from active rock glaciers because they tend to have stabilized, vegetated fronts which are less steep than the fronts of active rock glaciers. Also, active rock glaciers tend to display a sharp angle of contact between the front of the rock glacier and its top surface (Wahrhaftig and Cox 1959, p. 392). Where inactive rock glaciers are found, they indicate a previously more rigorous climatic regime. Because of this, they are seen as valuable paleoclimatic indicators. Barsch and King (1975) were able to use radiocarbon and palynological evidence to date several inactive rock glaciers. From this information they inferred two separate rock glacier advances in the Swiss Alps and correlated these advances to past climatic regimes.

Inactive rock glaciers are found below present-day active forms in the Alaska Range (Wahrhaftig and Cox 1959, pp. 428-9) and the Brooks Range, Alaska (Ellis and Calkin 1979, p. 416). They have been used to aid in reconstruction of climatic regimes in these areas by their elevational relationship to glacial features. Barsch and Updike (1971) were able to delineate a late-Pleistocene periglacial zone at Kendrick Peak, Arizona, based primarily on altitudes of inactive rock glaciers. One problem with using inactive rock glaciers as paleoclimatic indicators of permafrost, however, is that if they form from glaciers they may persist at elevations lower than the zero degree isotherm because of the insulating effect of the debris cover (Washburn 1980, p. 
354). Therefore, on ly inactive rock glaciers formed from interstitial ice can unequivocally be used to establish a limiting temperature. Unfortunately, these genetic forms are not easily recognized because of the often vegetated and/or eroded state of inactive rock glaciers.

\section{DISTRIBUTIONAL CONTROLS}

Active rock glaciers require for their existence an ample supply of rocky material and a climate conducive to the accumulation and persistence of an ice matrix/core capable of flow. In other words, rock glaciers exist in a topoclimatic zone that is cold enough to preserve sub-surface ice, but lacking in sufficient precipitation to allow ice glaciers to exist. This zone is generally accepted to be indicative of discontinuous permafrost and a periglacial environment (Smith 1973, p. 79; White 1976, p. 78; Washburn 1980, p. 230). Certain environmental factors can be recognized as crucial to the distribution of rock glaciers. These include geologic controls and climatic controls.

\section{Geologic Controls}

Geologic controls include the type of bedrock, degree of its jointing, and its weathering characteristics. Rock glaciers occur preferentially in bedrock with high cliffs which supply ample quantities of large blocky debris. Morris (1981, p. 336) found that bedrock jointing was a significant factor in rock glacier development in the Sangre de Cristo Mountains, Colorado. Rocks that fracture into large boulders, such as granite or greenstone, are significantly more conducive to rock glacier formation than platy, schistose rocks in the Alaska Range (Wahrhaftig and Cox 1959, p. 414). Similar preferences 
have been observed by other researchers (Kesseli 1941, p. 209;

Blagbrough and Farkas 1968, p. 820; Barsch 1977, p. 240; Luckman and Crockett 1978 , p. 540).

Coarse blocky debris is more suitable for rock glacier formation because of its relative stability in holding steep slope angles as well as its ability to provide surface openings and interstitial voids for accumulation of an ice matrix. Conversely, platy weathering rocks are less stable on slopes, and probably are less conducive to flow if cemented by ice (Wahrhaftig and Cox 1959, p. 414). In contrast, Ell is and Calkin (1979, p. 418) found an abundance of rock glaciers composed of platy siltstones, shales and phyllites in the Brooks Range of Alaska.

\section{Climatic Controls}

Temperature and precipitation are the most important factors in understanding rock glacier distribution. These variables are manifested in the elevation and orientation of rock glaciers and vary according to the effects of latitude, continentality, and topography.

The altitudinal zonation of rock glaciers follows a general latitudinal trend of decreasing elevation poleward. This, of course, is due to decreasing levels of solar radiation and the progressive lowering of average annual temperatures toward the poles. Thus, rock glacier deposits on Mount Kenya, at the equator, occur at 4,000 meters (Mahaney 1980, p. 492), while those reported in Antarctica are found as low as 110 meters (Hassinger and Mayewski 1983, p. 355). In the tropics, rock glacier development is inhibited by the absence of deep freezing even at high elevations, due to diurnal rather than annual frost cycles.

Rock glaciers are most abundant in continental alpine regions and 
noticeably less abundant in areas with predominantly maritime $c$ limates where the lower snowline, greater depth of snowpack, and lower elevational occurrence of glaciers inhibit rock glacier formation (Thompson 1962, p. 218). Thus, rock glaciers are much more common in the continental climatic regime of the Rockies than along the Pacific Coast of North America. Active rock glaciers in the northern Swiss Alps are "missing to rare," whereas they are widespread throughout the more continental central and eastern Alps (Barsch 1977, p. 240).

In the Alaska Range, the altitudinal zone of active rock glaciers displays a mean elevational increase of about 100 meters over a 40 kilometer span between its southern and northern edges (Wahrhaftig and Cox 1959, p. 407). This is attributed to heavier precipitation, cloudier conditions, and cooler summer temperatures in the south. A similar elevational response to continentality occurs in an easterly direction in the Canadian Rockies (Luckman and Crockett 1978, p. 546).

Topography is extremely important in terms of its shading effects. The preferred north-facing orientation of rock glaciers in the northern hemisphere is well documented, particularly at mid-latitudes (Wahrhaftig and Cox 1959, pp. 406-7; Blagbrough and Farkas 1968, p. 814; Barsch 1977, p. 240; White 1976, p. 89; Luckman and Crockett 1978, p. 546). Deviations from a northward orientation occur primarily where high, steep-sided cliffs block incoming solar radiation through much of the year, allowing temperatures to remain low enough for ice preservation. Another effect of topography is the ability of mountains to create a precipitation shadow on their leeward slopes. This is related to continentality and expressed in the North Cascade Range, Washington, 
where rock glaciers are found only on drier eastern slopes (Thompson 1962, p. 215).

A final topographically related influence pertains to snow accumulation by wind-drift and avalanching; this effect is most pronounced on the lee-side of broad upland surfaces (Morris 1981, p. 330). Snow and debris derived from wind-drift and avalanching may be incorporated into the rock glacier mass. In areas where wind-drift is substantial, however, sufficient snow may be deposited in the leeward basin to favor formation of glaciers rather than rock glaciers.

\section{ROCK GLACIER STUDIES IN THE PACIF IC NORTHWEST}

There have been no major study of rock glaciers in the Pacific Northwest. Several researchers have reported their existence, but few explanations have been given regarding their geomorphic and $c l$ imatic significance. Thompson (1962, p. 216-18) reported several active rock glaciers on the north side of Silver Star Mountain in the North Cascades and attributed their existence to sub-freezing temperatures, a relatively thin winter snowpack, and Balch ventilation. He contended that rock glaciers are relatively rare in the Pacific Northwest because there are few alpine areas where the snowpack is sufficiently limited to allow rock glaciers to develop.

At least 20 inactive rock glaciers have been reported with in or close to Mount Rainier National Park (Crandell and Miller 1974, pp. 38-44). These deposits were found to occupy predominantly north- or east-facing cirques containing abundant talus. All but two of these were found in an altitudinal range of 1,665 to $2,000 \mathrm{~m}$. The rock 
glaciers were considered to date back to a climatic regime somewhat colder and possibly wetter than present; they were correlated with McNeeley age glacial moraines, dated at 8,750 to 12,000 years B.P. (Crande 11 and Miller 1974, p. 56).

Long (1975a, p. 39-41) identified and briefly discussed rock glaciers in the northeast 0lympics. He considered the deposits to be nonglacial in origin and associated with areas of very steep slope and abundant talus. Five or six possible rock glaciers were reported. All but one were considered to be inactive because they support fairly dense stands of conifers and lack steep, unvegetated fronts.

The distribution of several rock glaciers in the Olympic Mountains was discussed by Nebert (1984), who attributed their presence to the combined factors of orientation, elevation, lithology, and climate, with climate being the dominant factor. He made an initial attempt to date two rock glaciers using lichenometry and tree-ring sampling, and concluded that the rock glaciers had been inactive for at least 250 years.

Other reports of rock glaciers in the Pacific Northwest include Hopk ins (1966, pp. 56-59) and Libby (1968, pp. 318-19) in the North Cascades, Kiver (1974, pp. 174-75) in the Wallowas, Carver (1972, p. 47-48) in the southern Oregon Cascades, and Scott $(1977, p .114)$ in the central Oregon Cascades. These reports are simply sightings of rock glaciers, and do little to integrate data on their morphology, genes is, distribution and age. The significance of rock glaciers as periglacial phenomena and possible indicators of permafrost has not been discussed. 
CHAPTER II I

AREAL SETTING

PHYSICAL SETTING OF THE OLYMPIC MOUNTAINS

Physiography and Geology

The 01ympic Mountains occupy the central portion of the $01 y$ mpic Peninsula of northwestern Washington (Figure 3 ). These mountains are separated from the Coast Ranges to the south by the wide, low-lying valley of the Chehalis River and are bounded by the Pacific Ocean and Strait of Juan de Fuca to the west and north, respectively. Narrow marine terraces ranging from 10 to $30 \mathrm{~km}$ in width separate the mountains from these coastal waters; the Hood Canal and Puget Sound form an abrupt boundary to the east. The mountains constitute the bulk of the olympic Peninsula, an area of approximately 10,400 square kilometers.

The $01 y$ mpics rise gently from the west for 30 to $50 \mathrm{~km}$ before reaching the high, rugged central and eastern portions of the range. Steep, serrate ridges in the interior commonly attain elevations between $1,400 \mathrm{~m}$ and $1,800 \mathrm{~m}$, while the taller peaks rise above 2,200 m. Mount 01 ympus, at $2,428 \mathrm{~m}$, is the highest point of the range. Unlike the gentle western slopes, the elevation gradient from the high central and eastern 0iympics drops steeply towards the eastern boundary. In just 13 $\mathrm{km}$ the elevation falls from $2100 \mathrm{~m}$ to sea level at Hood Canal (Fonda and Bliss 1969 p. 272).

Steep-walled, glaciated valleys radiate outward from the interior, 


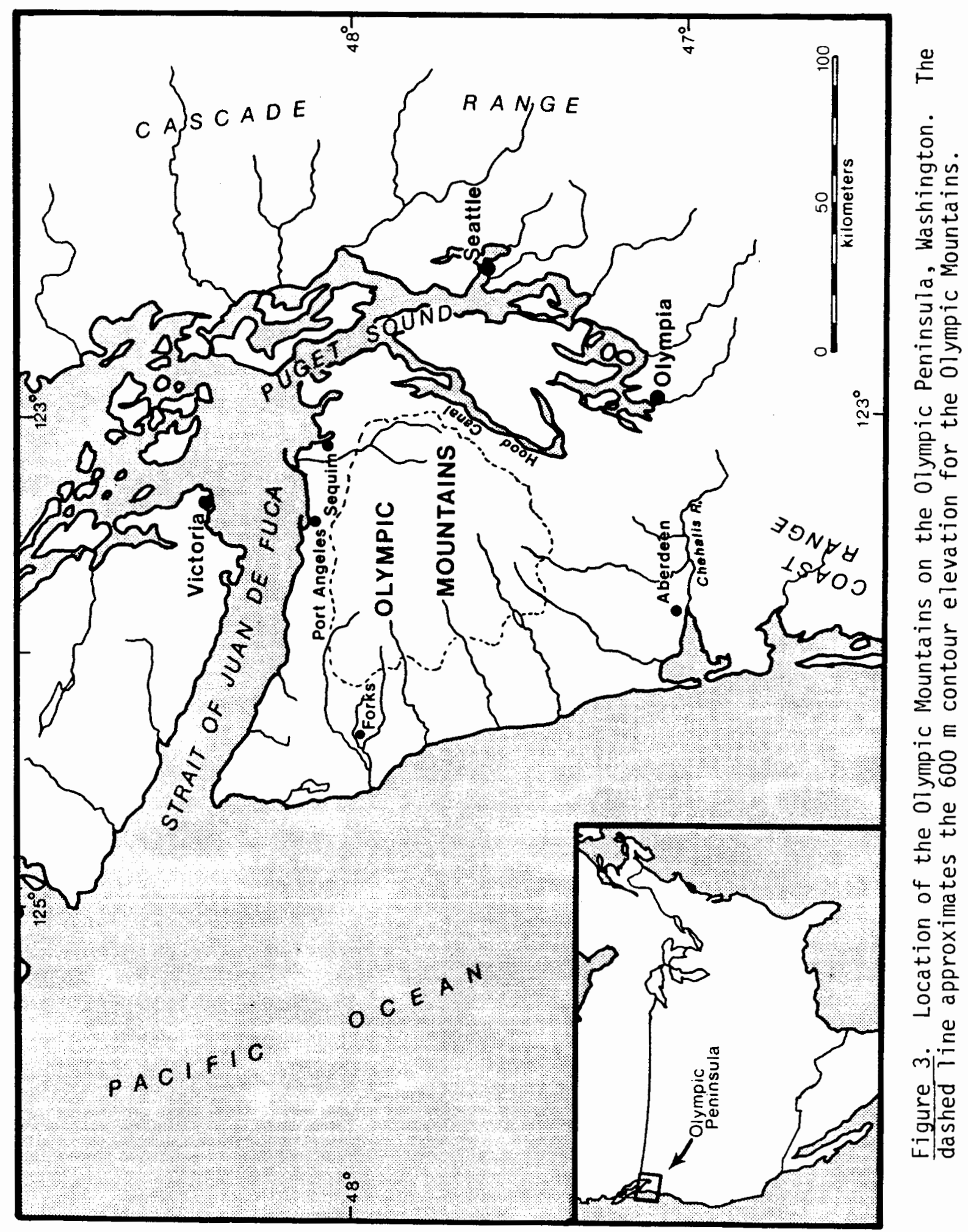


a result of domal upwarping of the central 0lympic massif (Figure 4). Major westward draining rivers include the Soleduck, Bogachiel, Hoh, Queets, and Quinalt. The Dungeness and Elwha Rivers empty to the north while the Quilcene, Dosewallips, Duckabush, Hamma Hamma and Skokomish flow eastward into Hood Canal. The Wynoochee, Humptulips and Hoquiam Rivers drain southward into the Chehalis River.

The 0lympic Mountains consist of two principal geologic terranes which result from tectonism associated with the collision and subduction of oceanic and continental plate margins (Tabor 1975, pp. 33-36; Mckee 1972, pp. 166-69). The first terrane, termed "peripheral rocks" (Tabor and Cady 1978a), is a westward-opening, U-shaped band of oceanic basalt overlain in places by younger folded and faulted marine sediments (Figure 5). The basalts, referred to as the crescent Formation, together with peripheral sedimentary rocks, were originally deposited off the continental margin and then pushed up against the continent when plates collided some 12 to 30 million years ago (Figure 6$)$. The peripheral rocks were less severely deformed because of the great mass and rigidity of the Crescent Formation basalts. Some of the more prominent peaks of the 0lympics are made up of the Crescent Formation basalts, including Mt. Constance $(2360 \mathrm{~m})$, Iron Mtn. $(2120 \mathrm{~m})$, The Brothers $(2100 \mathrm{~m})$, and Tyler Peak $(1940 \mathrm{~m})$.

The second terrane, known as the "core rocks", is composed of dark sandstones and siltstones, altered submarine basalts, and bedded chert which range in age from Eocene to Miocene (Tabor and Cady 1978a). The core rocks are separated from the peripheral rocks by coalescing faults such as the Calawah Fault on the north, the Hurricane Ridge Fault to 


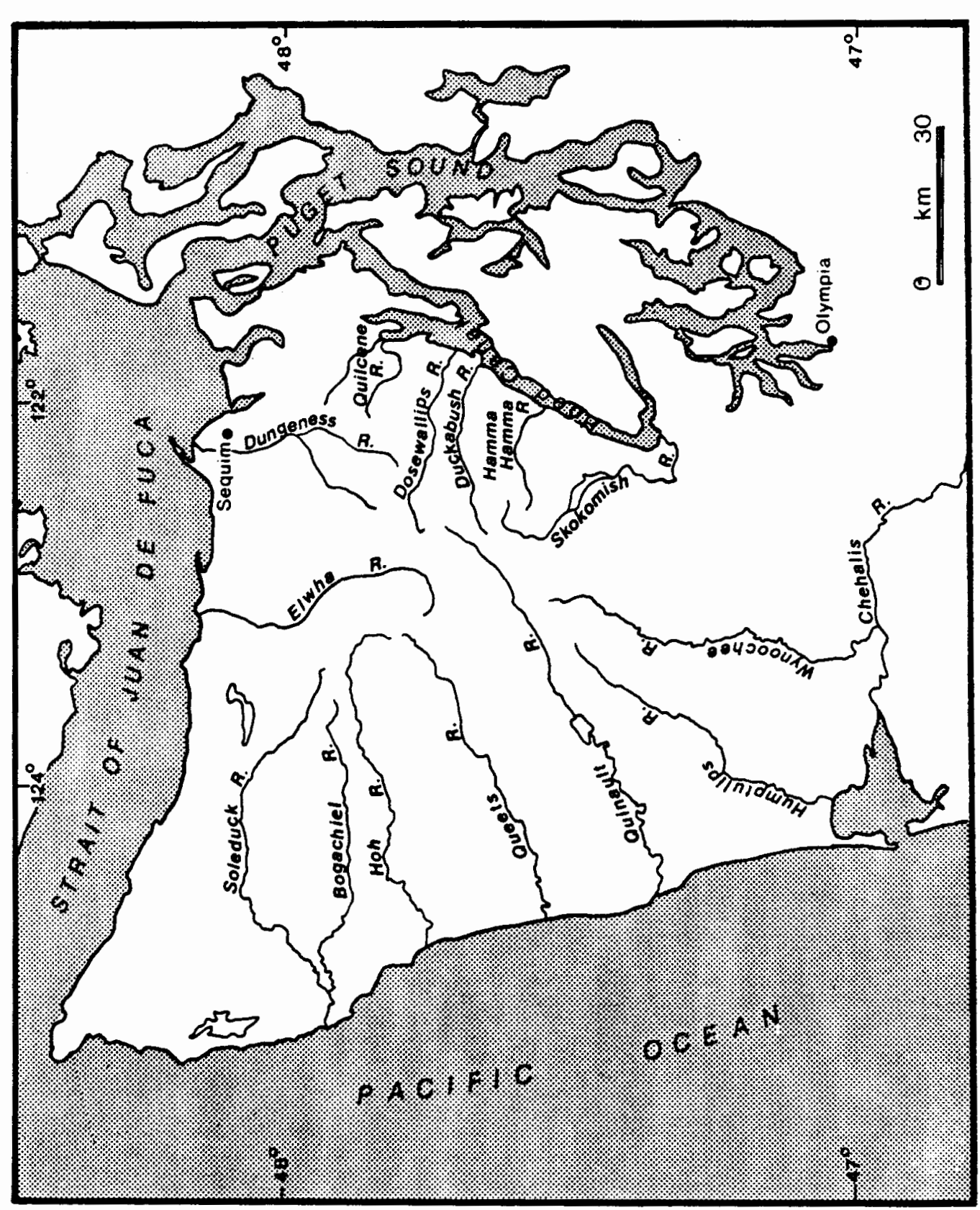

कำ

कิ

م

음

음

E

0
d
0
0
0
0

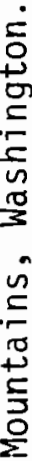

을

$\stackrel{9}{+}$

4

a

定

인

s

음

更

4
0
5
5
$\frac{0}{4}$ 


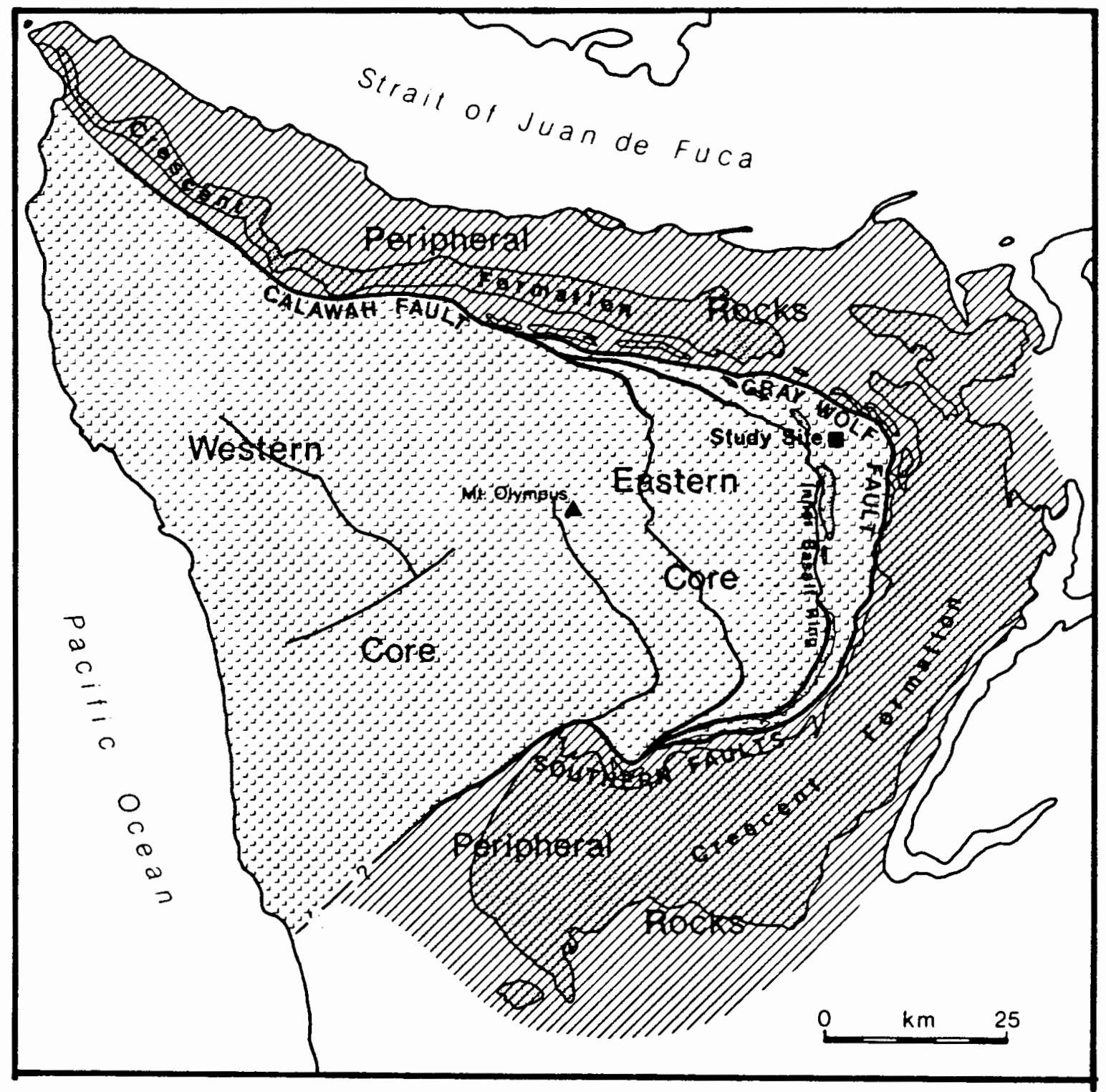

Figure 5. Geologic terranes of the Olympic Mountains. Adapted from Tabor and Cady (1978a, p. 5). 

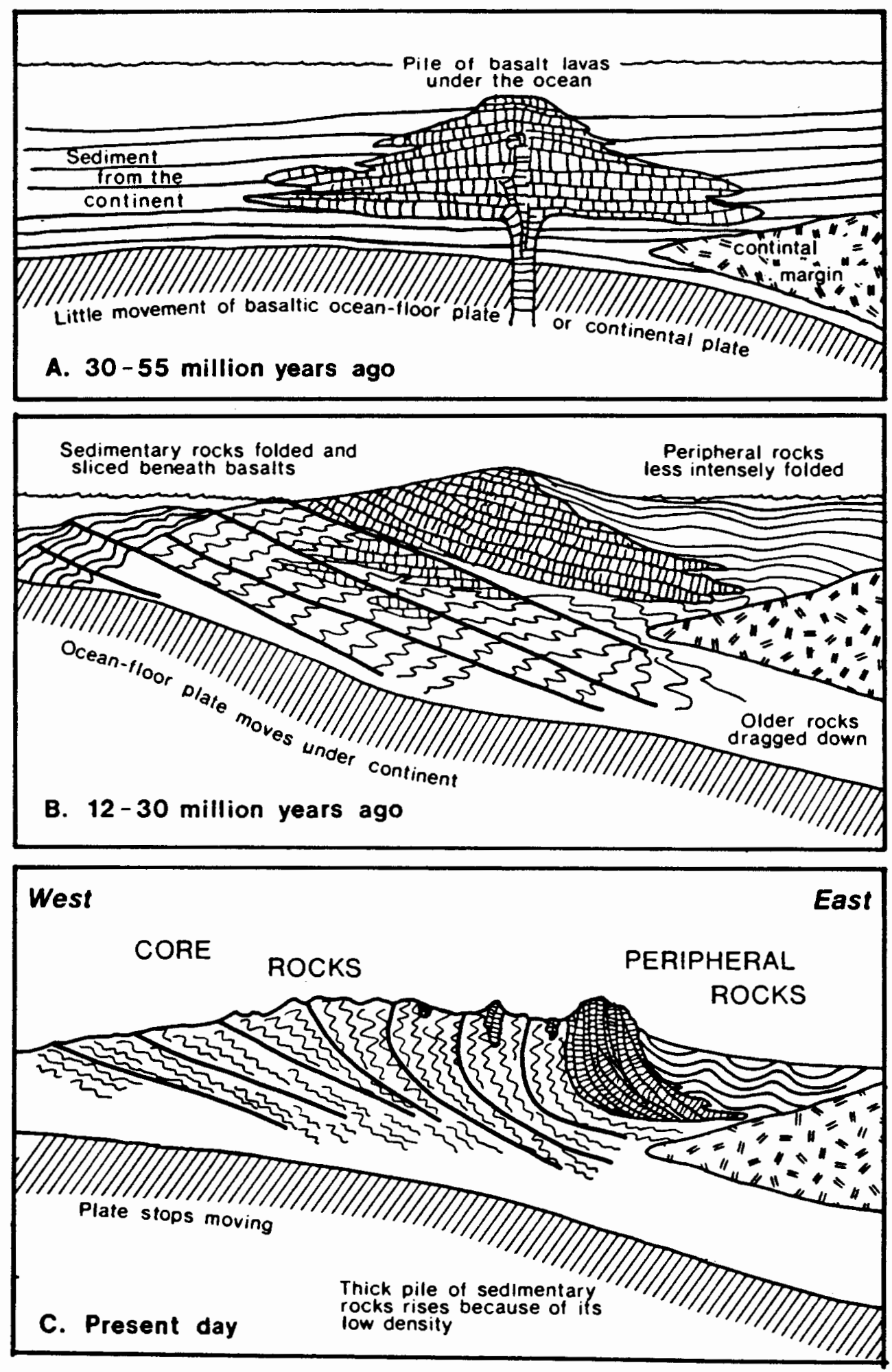

Figure 6. Formation of the 0lympic Mountains. Adapted from Tabor (1975, p. 39). 
the north and east, and several southern faults (Tabor and Cady 1978b, p. 5) (Figure 5).

Formerly referred to as the Soleduck Formation (Weaver 1937, p. 17; Mckee 1972 , p. 166), the core rocks have more recently been defined in terms of several lithic assemblages which form more or less concentric bands of rock separated by thrust faults (Tabor and Cady 1978a). The eastern core rocks are older and more highly disrupted than those in the west due to the greater compressive forces which occurred towards the plate collision area (Tabor 1975, p. 34). A discontinuous inner ring of basalts which erupted later than the Crescent Formation make up some of the higher peaks with in the eastern core. For example, the Needles Ridge in the northeast 0lympics rises steeply above the surrounding, less durable sedimentary core rocks.

Following the termination of subduction about 10 million years ago the sedimentary rocks, no longer subject to the downward drag caused by plate movement, began to rise upward in isostatic compensation (Figure 6). This upwarping caused additional folding and faulting as well as uplift of the 01 mmpic Mountains to an elevation near their present-day height.

\section{Climate}

The 01 ympic Peninsula is characterized by a marine west coast cl imate. Winters tend to be wet and mild, while summers are relatively dry and cool. The proximity of the Pacific Ocean and other water bodies has an ameliorating effect on temperatures, producing relatively small annual and diurnal temperature ranges, particularly at lowland coastal sites (Fonda and BT iss 1969, p. 273). 
The western slopes of the 0lympic Mountains receive more precipitation than any other area in the contiguous United States (NOAA 1985, p. 1171). In winter, moisture-laden southwest winds are channeled up the western Olympic Mountain slopes causing condensation and copious amounts of precipitation; the snowl ine occurs between $500 \mathrm{~m}$ and $1,000 \mathrm{~m}$ in mid-winter (NOAA 1985, p. 1172). High pressure dominates the region during the summer months and precipitation totals drop substantially. For example, the Quinalt Ranger Station in the southwest 01ympic foothills receives an average of $578 \mathrm{~mm}$ of precipitation during the month of December, but on ly $66 \mathrm{~mm}$ during July (Fonda and Bliss 1969, p. 274).

The precipitation shadow produced by the 0lympic Mountains is dramatic. Moisture is prevented from penetrating to the northeast by the mountain barriers of Mt. 01ympus and the Bailey Range, each receiving upwards of $5,000 \mathrm{~mm}$ of precipitation annually. Hurricane Ridge, which lies directly in the lee of these high barriers, receives an average of between 1,000 and $1,400 \mathrm{~m}$; and the town of Sequim, located at sea level, receives less than $500 \mathrm{~mm}$ (Figure 7). Thus, over a distance of about $65 \mathrm{~km}$, one can go from the wettest place in the contiguous United States to the driest west coast location north of Southern California.

\section{Glaciation}

Glaciation has played a significant role in shaping the present day Olympic Mountains. Cirques, aretes, U-shaped valleys and other alpine glacial features stand as remnants of past periods of inundation and sculpture by glacial ice. Over the past two million years, at least 


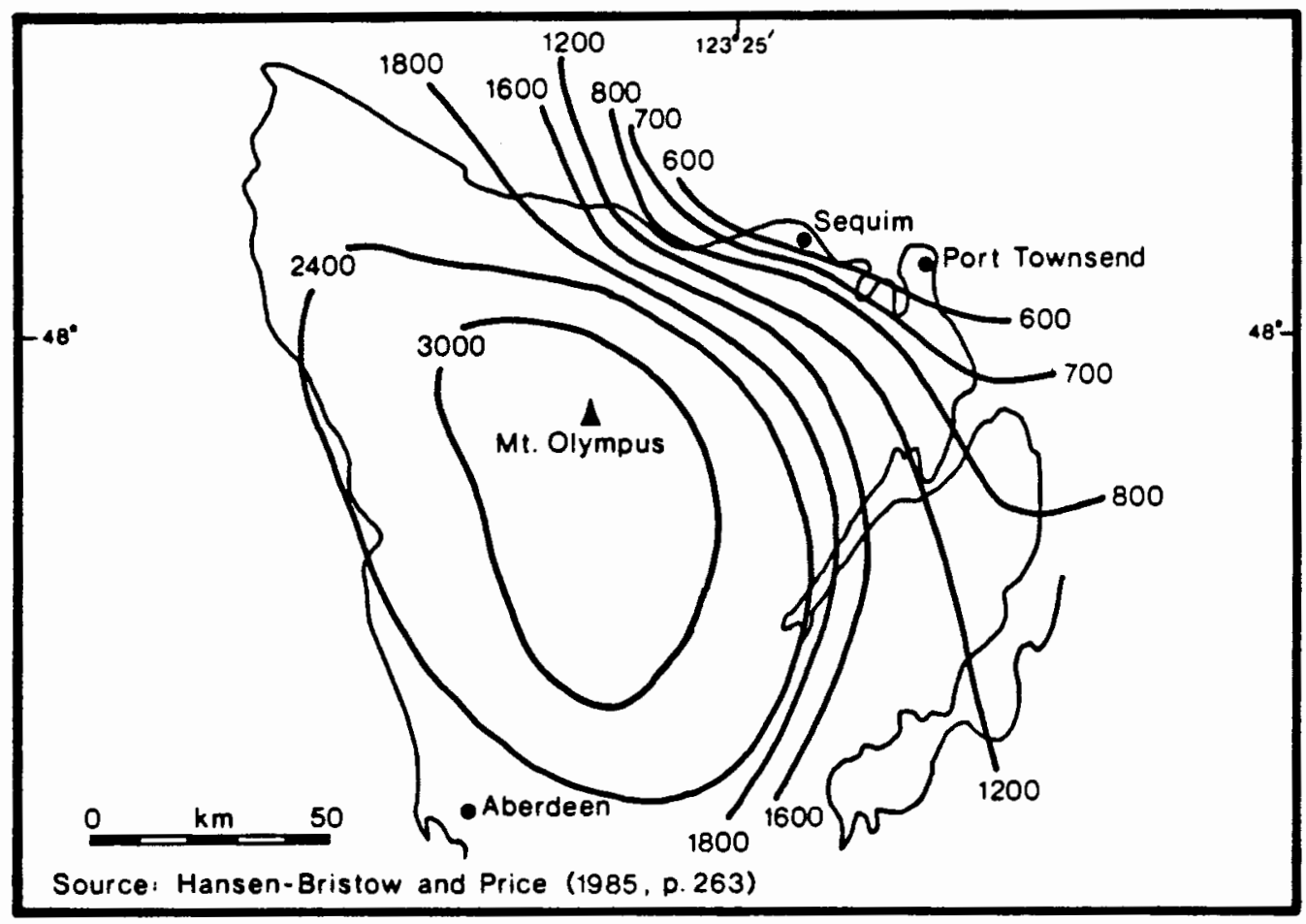

Figure 7. Annual precipitation (mm $\mathrm{yr}^{-1}$ ) of the 0lympic Peninsula.

four major alpine glacial episodes separated by interglacial periods have been recognized; these approximately correspond with advances of Puget and Juan de Fuca lobes of the Cordilleran ice sheet (Crandell 1965, p. 347) (Table I)

During times of maximum extent, alpine glaciers probably originated from an ice cap in the high central portion of the 0lympics (Easterbrook and Rahm 1970, p. 82). Long valley glaciers extended beyond the mountain front in the southwestern 0lympics, leaving deposits of glacial till that mark the furthest extent of each of the four glacial episodes. On the northern and eastern fronts, however, the extent of alpine 
TABLE I

LATE PLEISTOCENE GLACIAL EVENTS IN WESTERN WASHINGTON

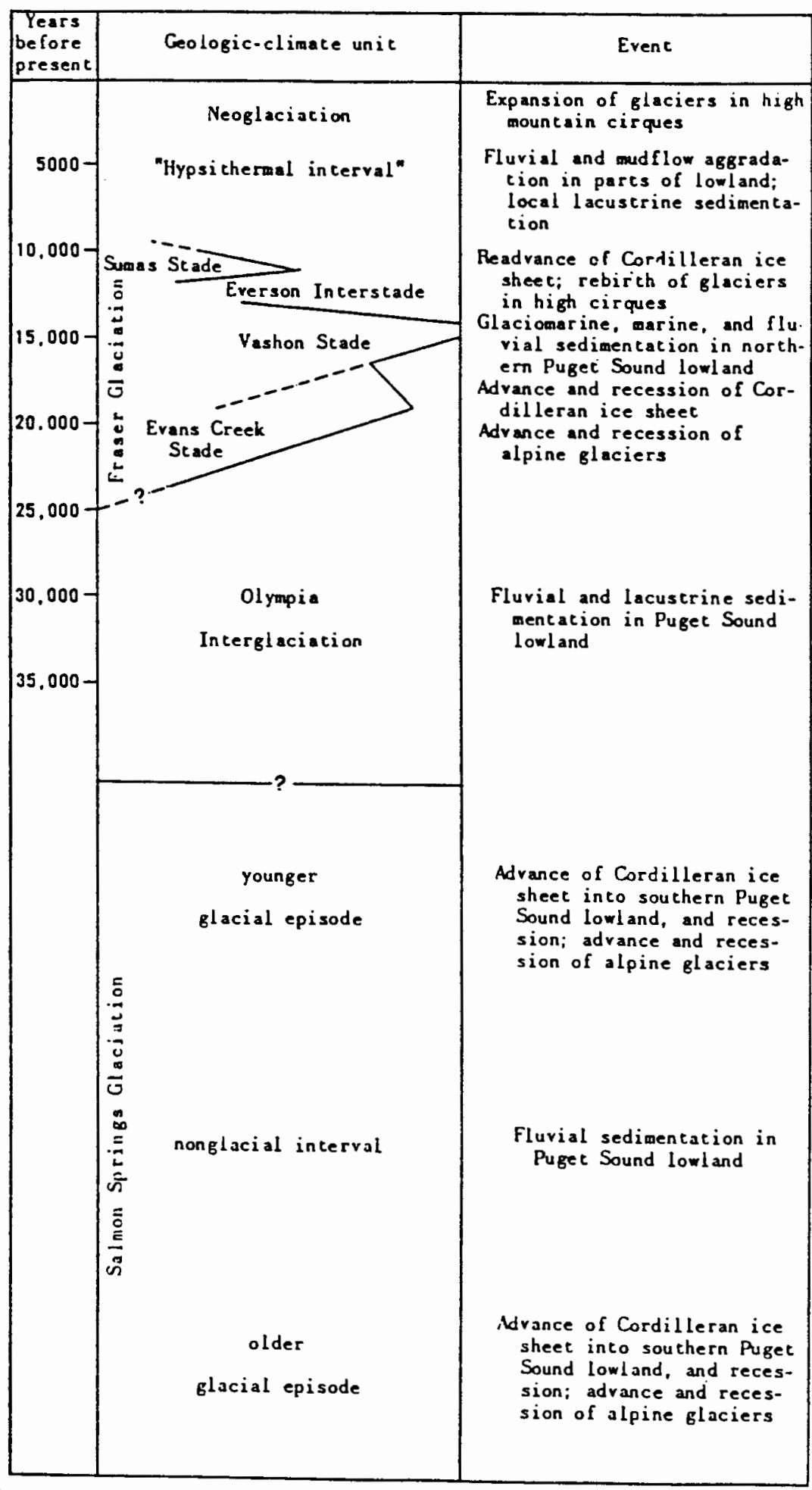

(From Crandell 1965) 
glaciation is less clear due to the encroachment of Cordilleran ice which deposited erratic boulders of granite and schist at altitudes of over $1,100 \mathrm{~m}$ along the northern front (Long $1975 \mathrm{~b}, \mathrm{p}$. i). The Cordilleran ice progressed several kilometers up northern and eastern Olympic drainageways causing the formation of pr oglacial lakes and mixing glacial sediments from exotic terranes with locally derived alpine glacial sediments (Long, 1975C).

Alpine glaciation in the northeast 0lympics was less extensive than in the central and western 0lympics because of its location in the Olympic Mountain precipitation shadow. High peaks in the northeastern 0lympics stood as nunataks and the effects of Pleistocene alpine glaciation become increasingly less visible northeastward. North-facing Pleistocene cirque floors are found as $10 \mathrm{w}$ as $1,000 \mathrm{~m}$ on the snowy western side of the 0lympics while they are not found below $1,800 \mathrm{~m}$ in the extreme northeast (Porter 1964, Figure 1, p. 477). Cirques that have been eroded out of the higher northeastern peaks are scattered and mostly uncon nected, producing a strikingly gentle and rounded appearance that contrasts with the jagged central and western peaks.

Several smaller, post-Pleistocene glacial advances have been recognized in the 0lympics. Heusser (1957) reported three Neoglacial advances on glaciers near Mt. 01ympus; Long (1974, 1975a) recognized either two or three Neoglacial advances in the northeast $01 y$ mpics, near the study site location. Approximately 60 active modern glaciers of the $01 y m p i c$ Mountains cover an area of about 65 square kilometers (Hubley 1956, p. 671), the bulk of which is centered about Mt. 0lympus. Other notable centers of glaciation in the 01 ympics include the Bailey Range, 
Mt. Anderson, and the Needles Ridge.

\section{Vegetation}

Dense coniferous forests blanket the slopes of the 0lympic

Mountains. Climatically controlled elevational forest zones can be used to broadly designate vegetation types; environmental factors such as aspect, soil type, drainage, and fire history play a more localized role in determining the distribution of vegetation.

The lower western slopes $(0$ to $500 \mathrm{~m})$ support a climax vegetation of western hemlock-red cedar (Tsuga heterophylla-Thuja plicata) except for a narrow zone dominated by Sitka spruce (Picea sitchensis) along the coast and up the major west-draining valleys (Kuramoto and Bliss 1970, p. 319). On the drier northern and eastern 0lympic foothills, Douglas-fir (Pseudotsuga menziesii) is more common in association with the western hemlock (Tsuga heterophylla).

The western montane zone $(550$ to $1,100 \mathrm{~m})$ consists of the Pacific silver fir-western hemlock (Abies amabilis-Tsuga heterophylla) cl imax forest; on the east side of the range, different mixtures of Douglas-fir (Pseudotsuga menziesii) and western hemlock (Isuga heterophylla) are found depending on fire history and slope orientation (Fonda and 81 iss 1969, p. 299).

The subalpine zone occurs between 1,100 and $1,650 \mathrm{~m}$ in the west near Mount 01 ympus as well as on north-facing slopes in the east-central part of the range. The dominant species in this zone are the Pacific silver fir (Abies amabilis) and mountain hemlock (Tsuga mertensiana). The subalpine fir (Abies lasiocarpa) becomes more dominant in the east, where the study area is located, between the elevations of 1,300 and 
$1,800 \mathrm{~m}$. Lodgepole pine (Pinus contorta) is common in sites recently disturbed by fire (Fonda and Bliss 1969, p. 299).

Subalpine meadows commonly occur as small openings between stands of subalpine fir (Abies lasiocarpa) or as larger clearings produced by fire. They vary in elevation from $1,350 \mathrm{~m}$ in the north-central $01 y \mathrm{mpics}$ to $2,000 \mathrm{~m}$ in the dry northeast. Subalpine meadows and forest are largely lacking west of Mount 01ympus because the mountains are too low to support subalpine vegetation (Kuramoto and Bliss 1970, p. 319). Climatic treeline is found only in the central and northeastern sections of the range, occurring at about $1,750 \mathrm{~m}$. At the timberl ine ecotone, stunted subalpine fir (Abies lasiocarpa) and lodgepole pine (Pinus contorta) typically give way to prostrate shrubs and low-lying perennial grasses and herbs.

Soils

Few soil studies have been conducted in the 0lympic Mountains, particularly in the upland areas. Fonda and Bliss (1969 p. 283) described two major soil types, Spodosols and Entisols, associated with forested locations. 0lympic soils are generally weakly developed because of their young age and rapid erosion rates. Soils tend to be very well-drained due to the abundance of sandstone as parent material. Much of the ground surface is snow-covered during several months of the year, thereby limiting the growing season and retarding the rapidity of soil formation. Finally, repeated fires have been responsible for increased soil erosion and destruction of soil organic matter (Fonda and Bl iss 1969, p. 283; Kuramoto and Bl iss 1970 , p. 327).

Kuramoto and Bliss (1970, pp. 327-29) described several subalpine 
meadow soils which typically overlie 01 ympic sedimentary core rocks. The soils were classed as Spodosols, Mollisols, and Inceptisols. Soil development varied due to differences in drainage, vegetation, snow coverage and other environmental factors.

Soils developed on upland glacial till and outwash are varied, with the majority being classed as Xerochrepts (Franklin and Dyrness 1973, p. 11). These soils tend to display a loam-textured surface horizon and a gravelly sandy loam substratum.

\section{STUDY SITE DESCRIPTION}

\section{Gray Wolf Ridge}

The study site is located at the northeast end of Gray Wolf Ridge, a southwest-northeast trending divide which separates the Gray Wolf River and Royal Creek drainage basins; it lies a few kilometers within the eastern boundary of 0lympic National Park (Figure 8). Although regularly maintained Park Service trails a long Royal Creek and the Gray Wolf River provide access to wilderness camping areas in these lower river basins, access to Gray Wolf Ridge is limited because of the steep, rugged topography and lack of maintained trails. Thus, the study site is isolated and infrequently visited.

Gray Wolf Ridge is within the $01 y$ mpic precipitation shadow, lying to the lee of Mount Olympus, the Bailey Range, and Needles Ridge. Because of this, the area displays a more continental climate than the western and central 01 ympics. However, summer temperatures still reflect the maritime influence. During the summer, advected fog moves up the north draining river valleys, keeping the mountains cooler and 


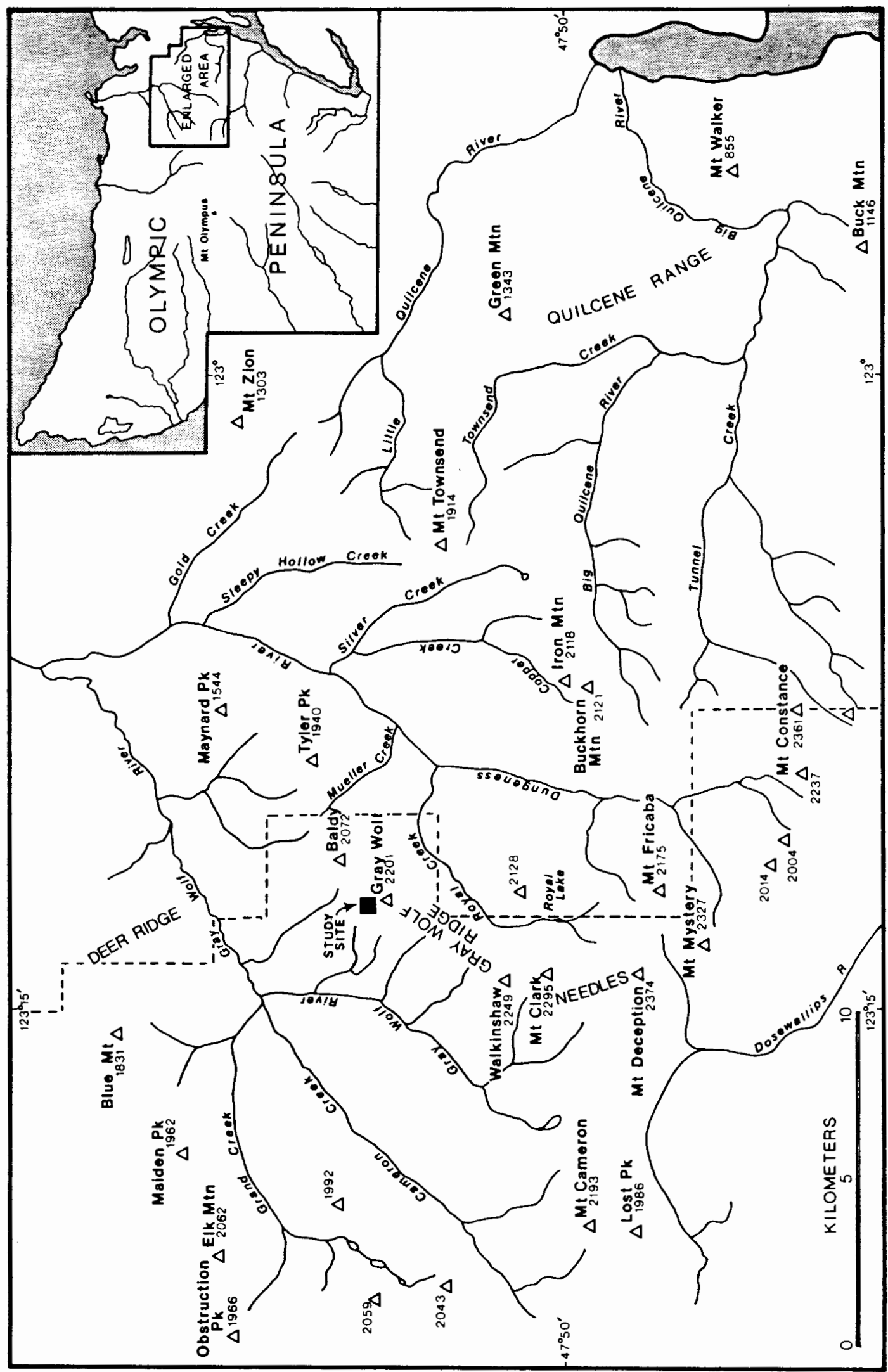

疍

ن

足

옹

ำ

엉

는

\& 2

\& $\frac{1}{0}$

은안

두

옹

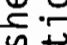

范

U.

을

तi

도

듬

음

0

完出

닐

동

志。

을

u

-

을

중

+ +

舟

元

†

을 을

응

둥

$\stackrel{0}{+\infty}$

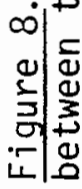


damper than more continental alpine areas such as the Rockies. Fonda and Bliss (1969, p. 286) estimated a mean annual temperature of $1.2^{\circ} \mathrm{C}$ for an elevation of about $1,650 \mathrm{~m}$ on Hurricane Ridge, which is located 15 to $20 \mathrm{~km}$ to the northwest. During the winter months, prevailing southwesterly winds sweep the high, expo sed windward slopes free of snow and deposit it in leeward cirques and nivation hollows, where it lingers until July or August in well-shaded areas.

Subalpine fir (Abies lasiocarpa) is the dominant treeline species along the ridge, although lodgepole pine ( inus contorta), mountain hemlock (Tsuga mertensiana), and a few Alaska-cedar (Chamaecyparis nootkatensis) occur as well. Treeline elevation varies from about 1,700 $\mathrm{m}$ on northeast exposures to over $1,800 \mathrm{~m}$ on southwest exposures.

Gray Wolf Ridge is composed of easily erodable interbedded sandstones, siltstones, and slaty mudstones of the Needles-Gray Wolf lithic assemblage, part of the eastern core rocks (Cady et al. 1972). The layers of more massively bedded sandstone tend to stand out in relief, forming the more prominent ledges and higher peaks along the ridge. The structure is complex, with the beds generally striking in a northwesterly direction and dipping to the southwest between $40^{\circ}$ and $85^{\circ}$; in several places along the ridge the bedding is overturned. Gray Wolf Peak, the highest point along the ridge, stands at 2,200 m. Mount Baldy, located approximately 2 kilometers to the northeast (Figure 8), may be considered an extension of the ridge because of its similar lithology. Tyler Peak, lying further northeast, and Mount Walkinshaw to the southwest are composed of basaltic rocks, thus defining lithologic boundaries for Gray Wolf Ridge. 
The steep, serrate morphology of Gray Wolf Ridge, together with several distinctive north to northeast oriented cirques are evidence that the ridge was subject to past glaciation. However, cirque floors and lower valleys do not exhibit obvious depositional evidence of glaciation in the form of moraines. Upper slopes along Gray Wolf Ridge commonly consist of steep bedrock, avalanche chutes, and talus. In places, nivation and solifluction appear to have bevelled the ridge, creating broad, gently sloping zones. These areas are particularly noticeable at north-oriented, wind-protected sites on low-lying cols along the ridge. The presence of frost-shattered boulders, patterned ground in the form of sorted and nonsorted stone stripes, turf-banked terraces, nivation hollows, talus, and protalus ramparts, as well as the Akela rock glacier all suggest that periglacial processes have been at work in this area.

Akela Rock Glacier

The Akela rock glacier is a tongue-shaped mass of angular to subangular boulders and fine debris (Figure 1). In profile, it extends approximately $400 \mathrm{~m}$ horizontally from toe $(1,750 \mathrm{~m})$ to head $(1,860 \mathrm{~m})$ (Figure 9). Its width varies from about $225 \mathrm{~m}$ near the base to $120 \mathrm{~m}$ near the head. The rock glacier slope averages about $15^{\circ}$, but varies

1The name "Akela" was given to this rock glacier by Austin Post of the United States Geological Survey in the early 1960's, and appears on aerial photographs taken by Post in 1964 and 1965. The name was taken from Rudyard Kipling's Jungle Books, in which Akela is the leader of a pack of gray wolves (Austin Post, written communication). The feature has also been called the "Gray Wolf" rock glacier, after the prominent peak on which it lies. The term "Akela" is used here because it is the earliest reference to the feature and is the term used by Long (1975a, p. 40) in his early description of the rock glacier. 


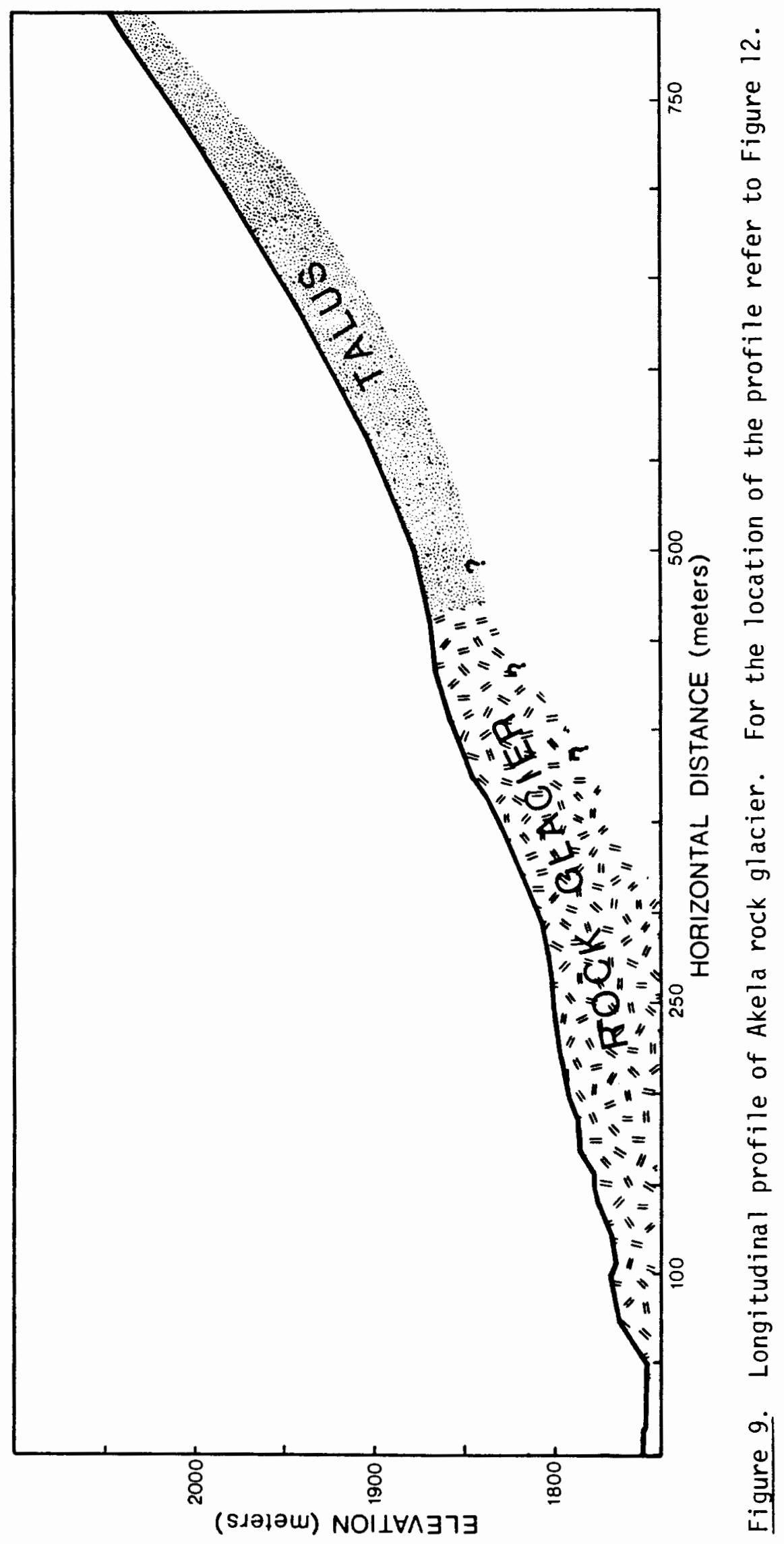


from $32^{\circ}$ at the face of the toe to about $5^{\circ}$ on its upper surface.

The rock glacier exhibits well-defined lateral ridges, several transverse ridges and furrows, a lower lobe and an upper lobe. The surface of the lower lobe is composed of several discontinuous ridges, furrows, and pits. The furrows and pits are mostiy bouldery, with interstitial voids evident between the boulders (Figure 10). Exceptions are the furrow and pit lying towards the eastern part of the lower lobe; these have been infilled with finer sediments and overgrown with vegetation. The ridges display a moderate to dense growth of erect and partially stunted subalpine fir (Abies lasiocarpa) and mountain hemlock (Tsuga mertensiana), often with an undergrowth of white heather (Cassiope mertensiana) and partridgefoot (Luetkea pectinata).

The surface of the upper lobe is flattish in comparison to the multiple transverse ridges and furrows of the lower surface. A large percentage of the upper surface remains unvegetated and is marked by several shallow, discontinuous longitudinal furrows which terminate at the distinctive large boulder pits near the lower part of the upper surface (figure 11). Dense stands of stunted subalpine fir (Abies Lasiocarpa) inhabit the lateral ridges and upper face of this lobe.

There is no surface water drainage on the rock glacier. Instead, rainwater and snowmelt percolate through the porous surface and exit one of two different routes. Some of the water wells up in a small, clear perennial lake which abuts the rock glacier at its base; this is apparently the result of diffuse percolation through the rock glacier. The rest of the water exits the rock glacier by means of a small stream that issues from the base of the northwestern corner of the rock 


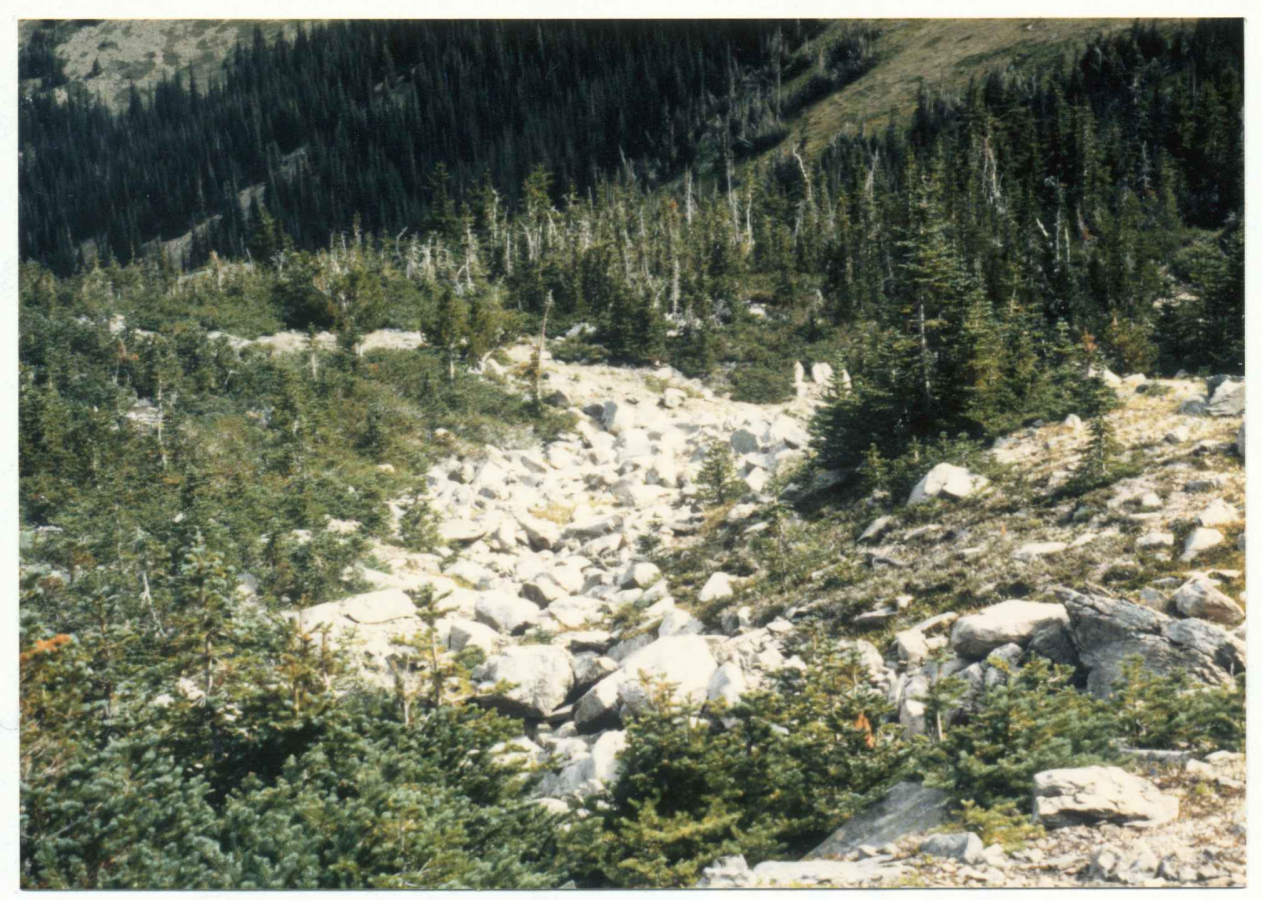

Figure 10. A bouldery transverse furrow on the surface of Akela rock glacier.

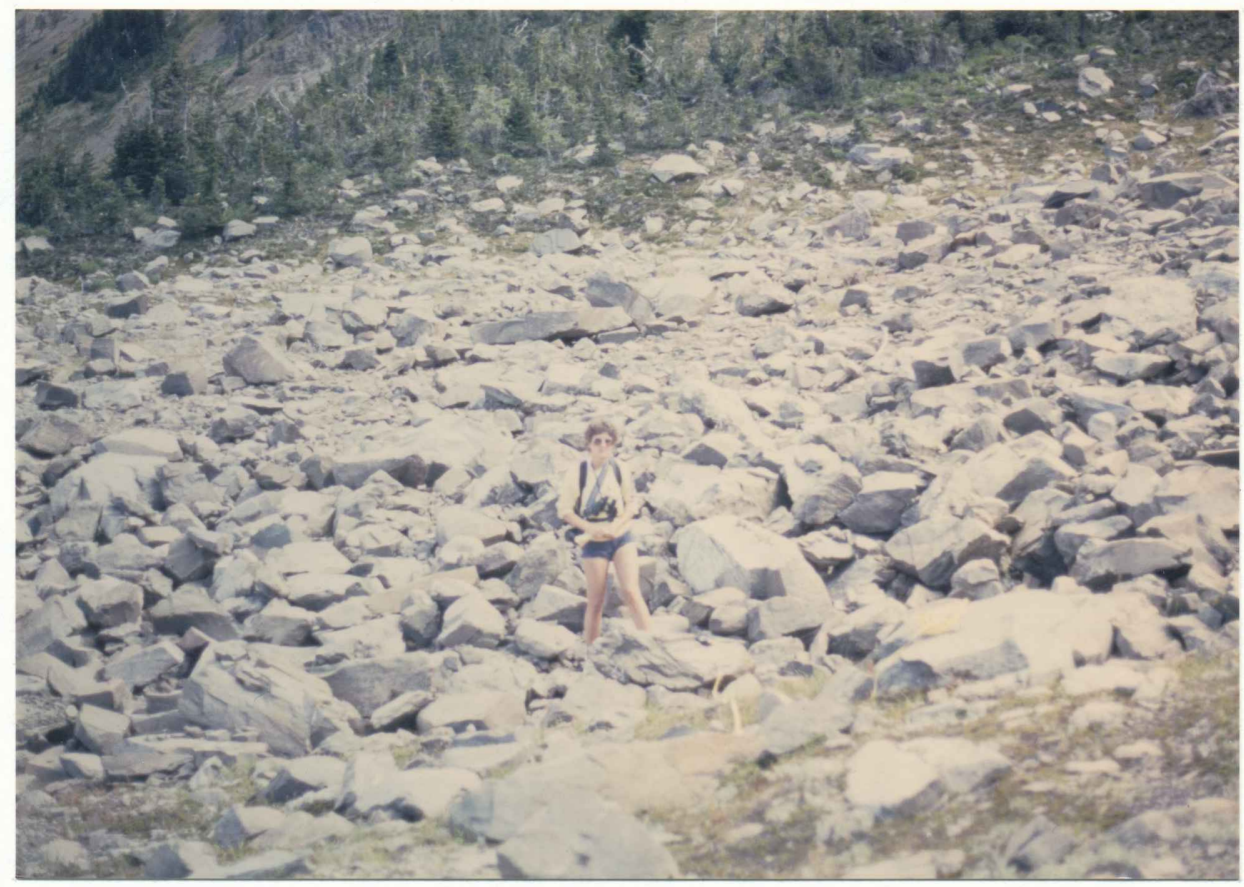

Figure 11. A boulder pit on the upper surface of Akela rock glacier. 
glacier, flows approximately 75 meters through a meadow and empties into a shallow, murky pond. The toe of the rock glacier, in conjunction with outcropping bedrock, separates the two water bodies. Outlets from both the clear lake and murky pond cut through a resistant bedrock ledge and drop steeply into the valley b elow; they join several hundred meters downstream.

Cirque Headwall and Talus

The cirque headwall above the rock glacier consists of angular outcrops of interbedded sandstone, siltstone, and slaty mudstone. Bedding thickness and jointing is highly variable; siltstones and slaty mudstones occur in thin to medium beds $(3$ to $30 \mathrm{~cm})$ and sandstones occur in thin to very thick beds $(3 \mathrm{~cm}$ to $>1 \mathrm{~m})$. Jointing in the slaty mudstones is extremely fine; this material commonly breaks off in sharp pencil-like fragments of less than one $\mathrm{cm}$ diameter. Sandstone jointing is more variable, occurring at spacings between three $\mathrm{cm}$ and two $\mathrm{m}$. The slope of the headwall varies, but averages between $40^{\circ}$ and $50^{\circ}$. In places, the weaker, more easily eroded siltstones and slaty mudstones undercut the more thickly bedded sandstones. This has the effect of creating overhangs of sandstone which eventually break off and fall as blocks across the talus surface.

The talus above Akela rock glacier forms a concave-upward slope profile, with the steepest upper portion reaching angles of greater than $34^{\circ}$ (Figure 9). It consists of angular, blocky to fine debris which forms subdued cones and swales below the cirque headwall. The cones are located below highly eroded couloirs and contain mostly cobble-sized and smaller debris; in contrast, the swales tend to accumulate a greater 
proportion of the larger blocks. A broad, gentle threshold at the base of the talus separates the lower talus from the head of the rock glacier. This threshold area is dissected by a bouldery furrow which connects the upper slopes of the rock glacier to a shallow pit at the talus base. 
CHAPTER IV

METHODOLOGY

Initial field work in the 0lympics occurred during the summer of 1983, while the author was a student in the Mountain Geography Field Camp at Portland State University. During that time, five days were spent in the area and two of these days were spent studying the orientation of boulders on the talus above Akela rock glacier (Welter 1983). The bulk of the field work was, however, conducted during the summer of 1986 at Akela rock glacier. Additional data were collected for comparative purposes during visits to four other rock glaciers in the northeast 01ympics. Field work pertaining to the geomorphic character of Akela rock glacier included surveying and mapping, collection of data regarding surface boulder size and fabric, and assessment of talus activity. The remaining field work focused on determining the age of the rock glacier. Tree core samples were taken, and measurements of lichen growth, boulder weathering, and soil development were made. Except for measurements of lichens, a 11 distances and lengths were taken in Standard English Units and were converted to metric units.

Laboratory work involved soil particle-size analys is using the hydrometer method (See Appendix). In addition, topographic maps, geologic maps, and aerial photographs were examined to determine the distribution and character of rock glaciers in the 0lympics. 
In a preliminary field survey the major morphological features of Akela rock glacier were mapped onto an aerial photograph. A longitudinal transect was established through the center of the rock glacier up to the base of the cirque headwall (Figure 12). Measurements were made along the transect using a 50-foot cloth tape, Brunton Pocket Transit, and Abney Hand Level.

Three sites on the rock glacier were selected to collect data on boulder size, fabric and weathering, and lichen growth (Figure 12). Each of these sites consisted of bouldery rubble with ample interstitial voids between boulders. Unlike much of the area on the rock glacier, these sites were free from vegetational encroachment. They were located in the lower, middle, and upper sections of the rock glacier in order to compare and contrast fabric, size and relative age characteristics on differing rock glacier surfaces. At each site, a population of 50 contiguous boulders was sampled.

Soil pits were dug at several sites on and adjacent to the rock glacier (Figure 12). At each site, soil color, structure, texture, and horizon thickness were examined in order to assess the amount of soil development. A Munsell Soil Color Chart was used to describe soil colors; structure, texture, and horizon thickness were evaluated visually and manually. Mineral soil samples were taken between depths of $20 \mathrm{~cm}$ and $25 \mathrm{~cm}$ at each site for laboratory analysis. In addition to the soil pits, a large pit was excavated in the meadow northwest of the rock glacier toe from which the stratigraphy of sedimentary deposits was examined and described; samples of organic material were taken for radiocarbon dating. 


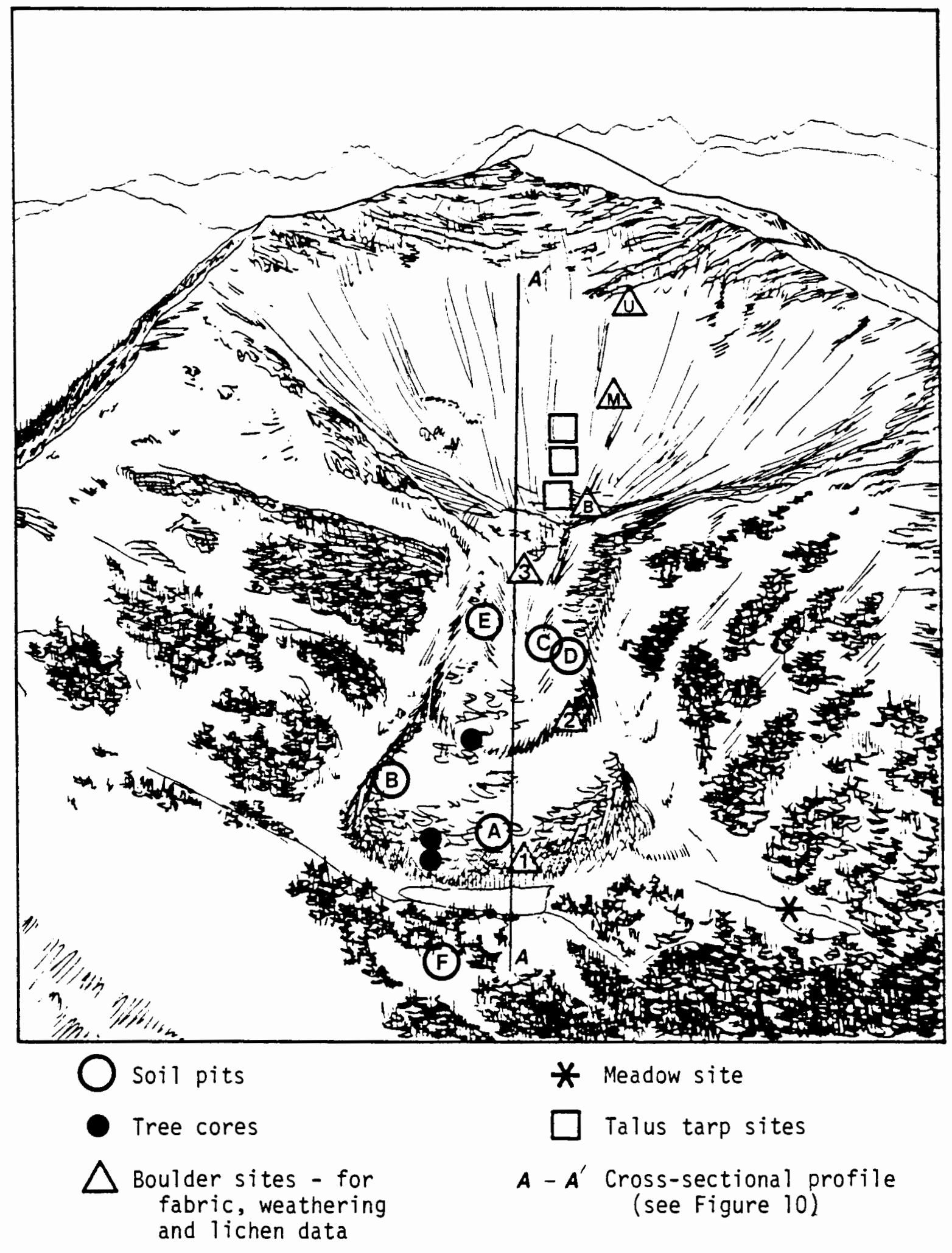

Figure 12. Locations of sampling sites on Akela rock glacier. 
CHAPTER $V$

DATA ANALYSIS

This chapter has been divided into two parts. The first part deals with geomorphic data regarding the size, fabric, and movement of surficial debris on Akela rock glacier and the talus above it. This is followed by a section that evaluates the data concerning the age of the rock glacier.

\section{GEOMORPHIC DATA}

\section{Size and Fabric Data}

Previous studies have indicated that rock glacier sediments may display a preferred orientation and crude sorting depending upon location on the rock glacier (Yarnal 1982, p. 385; Giardino and Vitek 1985 , p. 165). At Akela rock glacier, measurements were taken in order to compare and contrast the relationship between boulder size, fabric, and local slope angle at each site, as well as between sites. Size and fabric data were collected at three sampling sites on the rock glacier; additional orientation measurements were taken by Welter (1983) from the talus above the rock glacier (Figure 12). The elevation, slope, and orientation of each site are given in Table II.

Size. Boulder size (Table III), as determined by long-ax is length, varies from a minimum of $20 \mathrm{~cm}$ at Site One to a maximum of $256 \mathrm{~cm}$ at Site Two. Boulders on the rock glacier toe, at Site Three, tend to be 
smaller and more uniformly distributed than at the other sites; the two upper sites show similar size distributions.

Clast length measurements were not taken from the talus samples above the rock glacier. Welter (1983, p. 11-12) reported boulder diameters up to $200 \mathrm{~cm}$ at the talus base; clasts averaged less than 10 $\mathrm{cm}$ at the middle talus site and less than $2.5 \mathrm{~cm}$ at the upper talus. Sediment size differences on a rock glacier have been variously attributed to source of sediments, time, or mode of transport and

\section{TABLE II}

ELEVATION, SLOPE, AND ORIENTATION DATA FOR BOULDER AND TALUS SAMPLE SITES AT AKELA ROCK GLACIER

\begin{tabular}{|c|c|c|c|}
\hline & $\begin{array}{l}\text { Elevation } \\
\text { (meters) } \\
\end{array}$ & $\begin{array}{c}\text { Orientation } \\
\text { (degrees) } \\
\end{array}$ & $\begin{array}{c}\text { Slope Angle } \\
\text { (degrees) }\end{array}$ \\
\hline Talus Upper & 2040 & $45^{\star}$ & 35 \\
\hline Talus Middle & 1928 & $45^{\star}$ & 25 \\
\hline Talus Base & 1863 & $45^{\star}$ & 11 \\
\hline Site 1 & 1850 & 340 & 24 \\
\hline Site 2 & 1770 & 351 & 26 \\
\hline Site 3 & 1753 & 15 & 32 \\
\hline
\end{tabular}

* Estimated from aerial photograph

deposition (Yarnal 1982, p. 384). With time, smaller sediments tend to be sifted downward as a rock glacier moves forward (Barsch 1971, p. 205). Other modes of transport and deposition such as avalanching, talus accumulation, and glacial deposition would mask evidence of this process, as would inactivity of the rock glacier. Different lithologic source areas, or variable jointing in the source area could produce 
differences in sediment size concentrations on a rock glacier.

TABLE III

LONG-AXIS LENGTH MEASUREMENTS* FOR BOULDER SAMPLE SITES

ON AKELA ROCK GLACIER

\begin{tabular}{lcccc}
\hline & Min & Max & Mean & St.D. \\
Site 1 & 20 & 221 & 92 & 46 \\
Site 2 & 38 & 256 & 91 & 44 \\
Site 3 & 30 & 137 & 68 & 26 \\
\hline
\end{tabular}

*A11 measurements are in centimeters Sample size $=50$

The limited number of sample sites on Akela rock glacier prohibits drawing conclusions regarding sediment size distribution on the feature. However, certain areas on the rock glacier, such as the sample sites, display concentrations of well sorted bouldery sediments with large interstitial spaces. Most of the rock glacier surface, however, is vegetated, and consists of a poorly sorted mixture of boulders and finer sediments. Apparently there are processes operating at the bouldery sites which prevent accumulation of the finer debris. Excavations at various locations on the rock glacier indicate that finer sediments fill the interstitial spaces between the larger boulders.

One way in which this may occur, as mentioned, is by movement of the rock glacier. Although recent movement may have occurred, most evidence points to lack of recent activity for the rock glacier. For example, boulders at Sites One and Two, located on the rock glacier lobe faces, display moderate to heavy lichen cover and surface oxidation. Another possible explanation for the lack of fine debris is recent 
deposition of the boulders. Because of their distal locations in relation to the cirque headwall, neither sites Two or Three would be likely to be composed of recently deposited boulders. In contrast, site One, at the rock glacier head appears to be slowly accumulating boulders via rockfall processes from the cirque headwall.

Finally, the lack of finer sediments at the sample sites may be caused by the subsurface removal of fine debris by concentrated groundwater flow. Snowmelt and rain carry finer sediments downward through the large interstitial spaces separating the boulders. Below the surface, the same stream which exits the toe of the rock glacier transports the finer debris away from the bouldery areas.

Various modes of debris transport and deposition appear to have influenced sediment distribution on the rock glacier. In particular, rockfall and avalanche processes have scattered boulders across the upper rock glacier surface. These freshly weathered boulders often lie perched upon other boulders which are set into the surface sediment matrix. The fine sediments may be composed of wind-deposited sediments as well as particles weathered in situ or transported downslope via mass-wasting.

Fabric. Previous studies have indicated that the long axes of clasts in mass-wasted rock debris acquire orientation in response to the mechanics of motion (Lundqvist 1949; McSaveny 1971). Mean long-axis orientation, dip, and circular variance of the boulders were found by calculating the vector resultant of each sample population in the manner described by Davis (1986, p. 316-21). Rayleigh's Test for preferred trend was performed using the mean resultant length of each sample 
population as the critical value (Davis 1986, p. 324).

Clast orientation data for the boulder sites on Akela rock glacier are given in Table IV and illustrated in Figures 13 and 14. Clast orientations at boulder Sites Two and Three show weak preferred trends at the $5 \%$ level of significance. Boulders at both Sites Two and Three display mean orientations very close to slope direction. At Site one there is no preferred trend or tendency toward alignment with slope.

\section{TABLE IV}

CLAST ORIENTATION DATA FOR BOULDER AND TALUS SAMPLE SITES AT AKELA ROCK GLACIER

\begin{tabular}{lccccccc}
\hline & $\begin{array}{c}\text { Vector } \\
\text { Resultant }\end{array}$ & $\begin{array}{c}\text { Preferred } \\
\text { Trend }\end{array}$ & $\begin{array}{c}\text { Slope } \\
\text { Direction }\end{array}$ & & Clast Orientation & Mean & Circular \\
Talus Upper & .28605 & Yes & $45^{\star \star}$ & 21 & 40 & 41 \\
Variance
\end{tabular}

* Rayleigh's Test for preferred trend, $5 \%$ level of significance **Estimated from aerial photograph Orientation and variance measurements are in degrees; sample size $=50$.

Clasts at the middle and upper talus sites show a weak preferred trend and strong modal orientation with slope; the talus base clasts have the weakest alignment of the talus sites (Table IV). At all sample sites the circular variance is high. This variance can be 


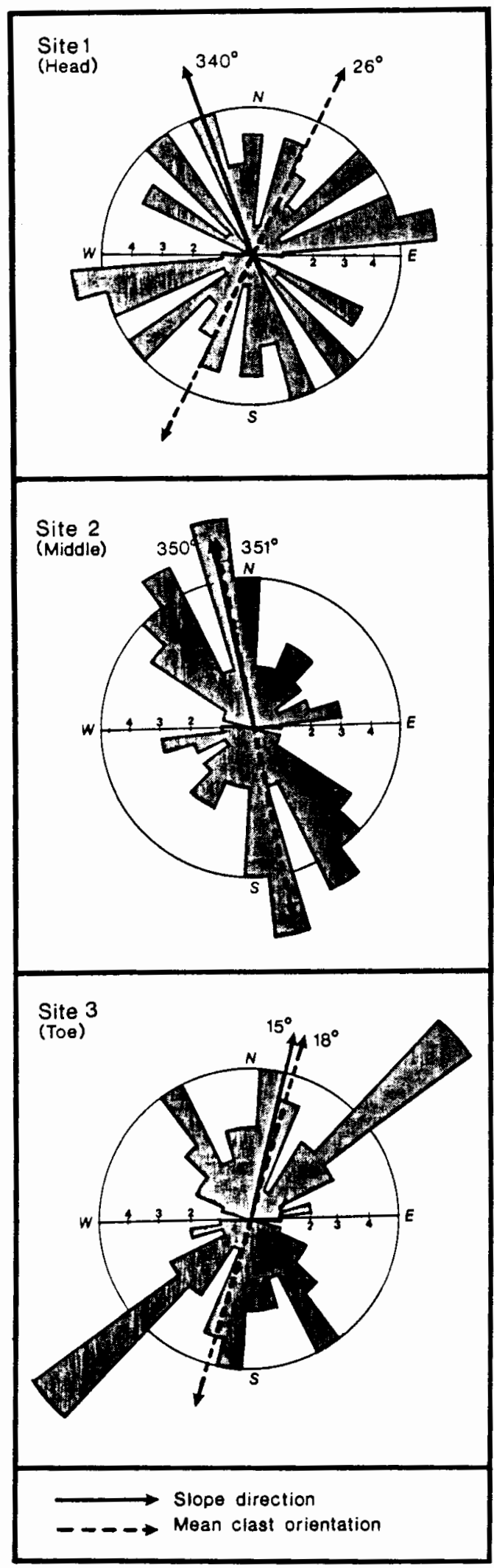

Figure 13. Long-axis orientation of 50 boulders from sample sites on Akela rock glacier. 


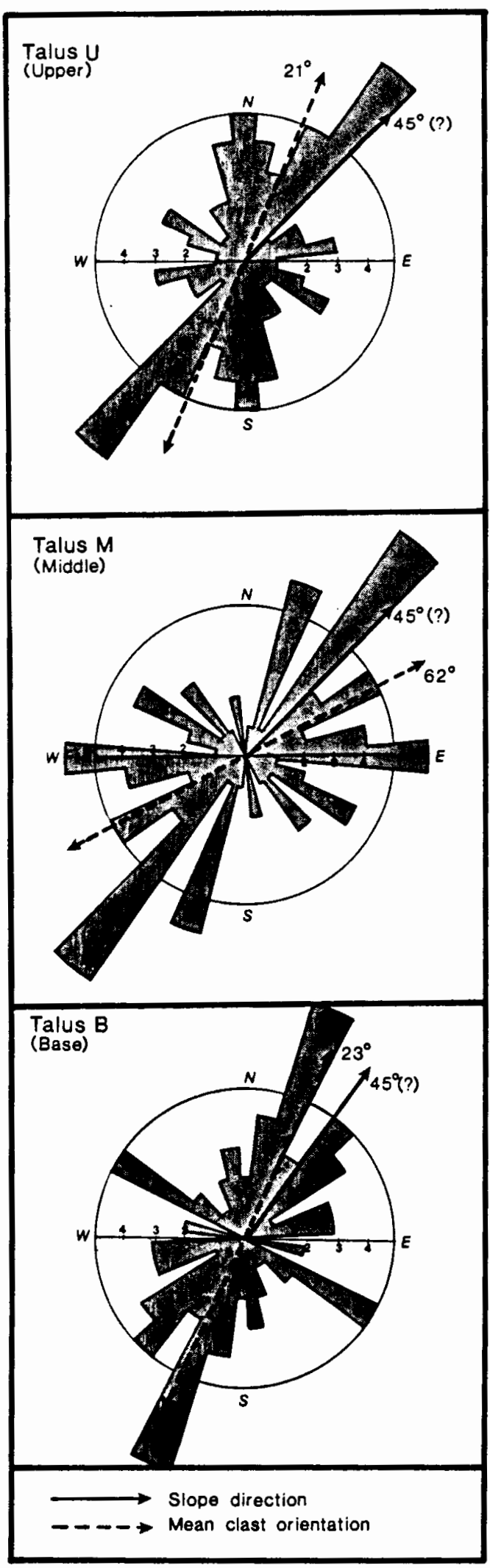

Figure 14. Long-axis orientation of 50 boulders from talus sample sites. 
expected because the rough and varied angular surfaces of the clasts tend to affect the orientation of adjacent clasts (Rapp 1960, p. 171). Thus, clasts are often slightly deflected from true parallel alignment with slope, resulting in an increased variance.

Giardino and Vitek (1985, p. 165) found a preferred orientation at all 20 sample sites of an active rock glacier in Colorado, suggesting that clast orientation has a tendency to align parallel to surface microtopography. Exceptions to this were clasts measured on the lobe faces and the talus above the rock glacier, which tended to align perpendicular to slope. It was suggested that lobe faces, like talus, were areas of greatest downslope movement. Others working on talus fabric have found that clast orientation may align parallel with slope (Rapp 1960; McSaveney 1971). Lobe faces at Akela have similar clast orientation characteristics to talus, implying a similar manner of downslope movement.

Based on the results of talus orientation measurements, Welter (1983) noted a tendency for less stable clasts on the upper and middle talus to display a greater preferred orientation than clasts at the talus base. It was expected that the boulders at Sites Two and Three on the rock glacier would show less tendency for preferred trend than at Site One, which was presumed to be the most recently active part of the rock glacier. Figure 13 indicates that this was not the case. Instead, boulders at the head (Site One) display a random orientation distribution.

The lack of a preferred trend at Site one may indicate that the boulders at this site have been disturbed by, or are responding to 
forces operating in more than one direction--e.g., avalanching from different source areas, subsurface collapse, or normal slope creep. In addition, the symmetrical distribution could mean that the boulders are primarily a depositional feature, the result of an accumulation process (Caine 1967, p. 803). Under these circumstances, there would have been little movement since deposition of the boulders in the upper part of the rock glacier. This suggests that there has been no motion in the upper portion of the rock glacier since the boulders were deposited.

The boulders at Sites Two and Three reflect the downslope orientation gained from shifting and falling of debris across the rock glacier lobe faces in response to past rock glacier motion. The fact that Site Three displays a larger variance than Site Two suggests that the lower lobe of the rock glacier ceased movement prior to the upper lobe. With less activity, the boulders settle into more stable positions, eventually losing preferred orientation.

Obviously, three sample sites are insufficient from which to draw significant conclusions regarding rock glacier activity. In order to more clearly portray the relationship between boulder orientation, slope, and rock glacier activity a greater number of sample sites will be needed.

Long-axis dip measurements (Figure 15) from the sample sites all display strong preferred orientation. Each sample population also tends to dip at an angle slightly less than the slope angle, showing a consistent upslope imbrication. In a study of surficial fabric of rockfall talus, McSaveney (1971, p.191) suggested that upslope imbrication contributes to surface instability; he does not, however, 


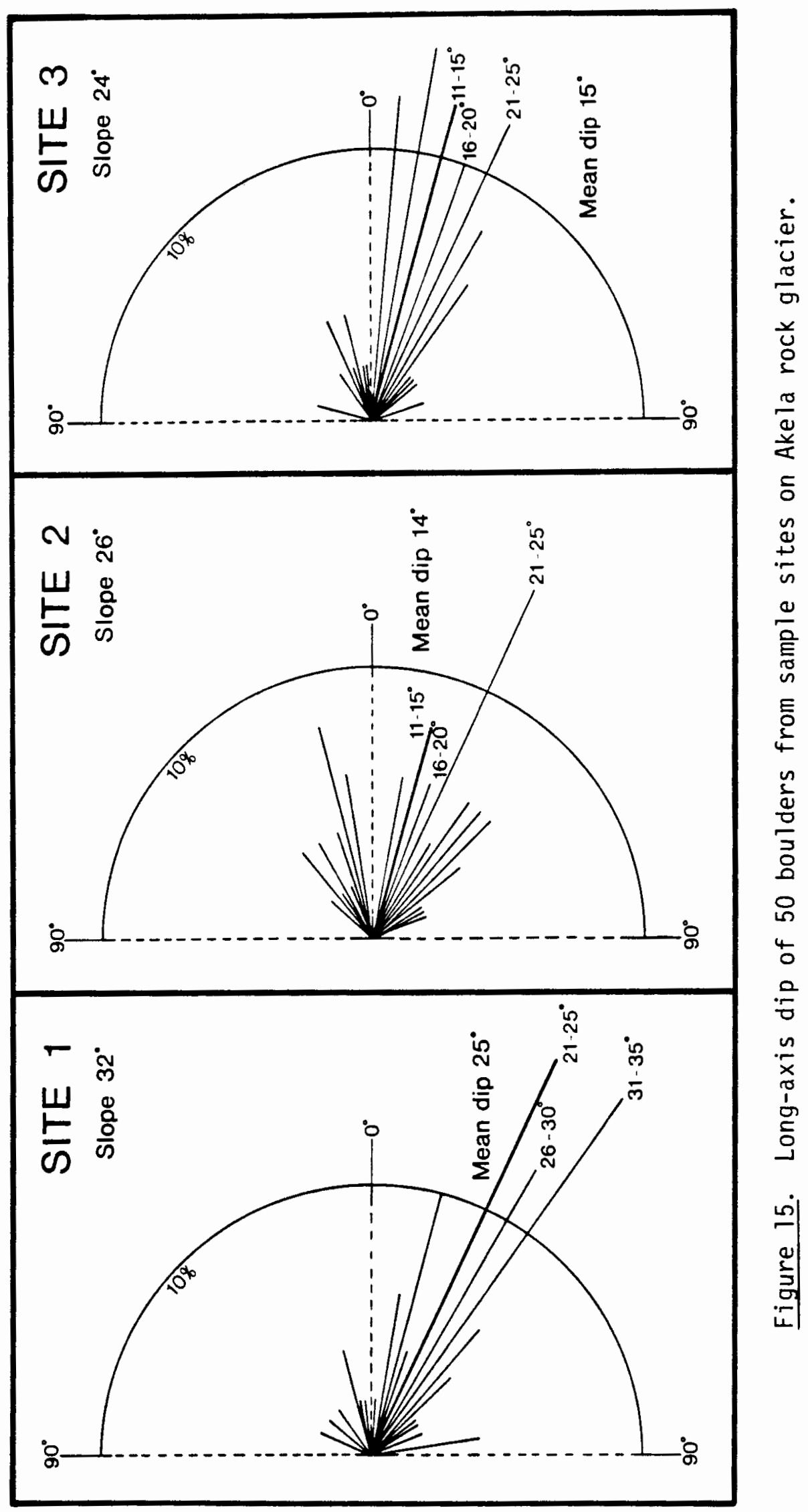


indicate that it is necessarily indicative of instability. Yarnal (1982, p. 381) reported a tendency for larger sediments on a rock glacier to lie close to horizontal, while smaller clasts were more likely to have a large dip angle. This relationship was not observed on the Akela rock glacier. The significance of imbricate structure of mass-wasted debris warrants further research.

\section{Talus Activity}

Contemporary talus activity was assessed in order to determine whether current processes were contributing to the rock glacier mass in its upper reaches. Repeat photography of three talus areas was used to monitor the amount of contemporary talus activity (Figure 12). During the summer of 1978 plastic tarps were laid out over the talus surface at each site; boulders were placed around the border of the tarps to secure them, while the center area was left clean so that any subsequent accumulation of debris could be measured (Larry Price, personal communication). Photographs were taken of each of the sites.

The next visit to the sites in 1983 revealed that the tarps were no longer intact due to the ravages of mountain weather. However, the sites could still be recognized because of the rectangular pattern left by the boulders used to secure the tarp borders, and by remnant plastic scraps lying beneath the boulders. Accumulation and movement of debris in relation to the rectangular boulder outline was assessed from photographs re-taken at each of the sites. Late-lying snow prevented discovery of two of the three sites in 1983. Onty two sites were relocated in 1985, and two in 1986. The lowest site (elevation 1,896 m) was photographed on each visit (Figure 16). When the 1978 photograph is 
compared to the one taken in 1985 (Figure 17), there is no apparent change in the boulder configuration, strongly suggesting stability of the talus at this site. Further support for talus stability at the lower tarp site is the presence of a Rhizocarpon lichen with a thallus diameter of greater than $40 \mathrm{~mm}$ on a boulder surface in the center of the site (Figure 18). As discussed in a later section of this chapter, a Rhizocarpon thallus diameter of this size probably indicates a stable rock surface for at least 200 years. Thus, even high magnitude events with long return intervals have evidently not crossed this part of the talus; of course, this assumes that the lichen was not pre-established upon the boulder before becoming situated in this position. Although none of the larger boulders appears to have moved significantly, smaller debris has accumulated on the tops of rocks in the more recent photograph, indicating the transport of smaller debris into the lower talus.

In contrast, a photograph taken in 1986 compared to the original 1978 photograph of a site slightly higher on the talus (elevation 1909 m) shows a moderate degree of debris movement and accumulation (Figures 19 and 20). In particular, boulders on the downslope border have been disrupted and moved downslope and the upper boulder border has been disrupted and inundated by new debris. Photographs of the third and highest site were not suitable for reproduction, but they indicate a moderate amount of perturbation of the border boulders, particularly on the downs lope end.

From this evidence, the talus appears to be more active towards midslope. The photographs from the middle site (Figures 19 and 20) 


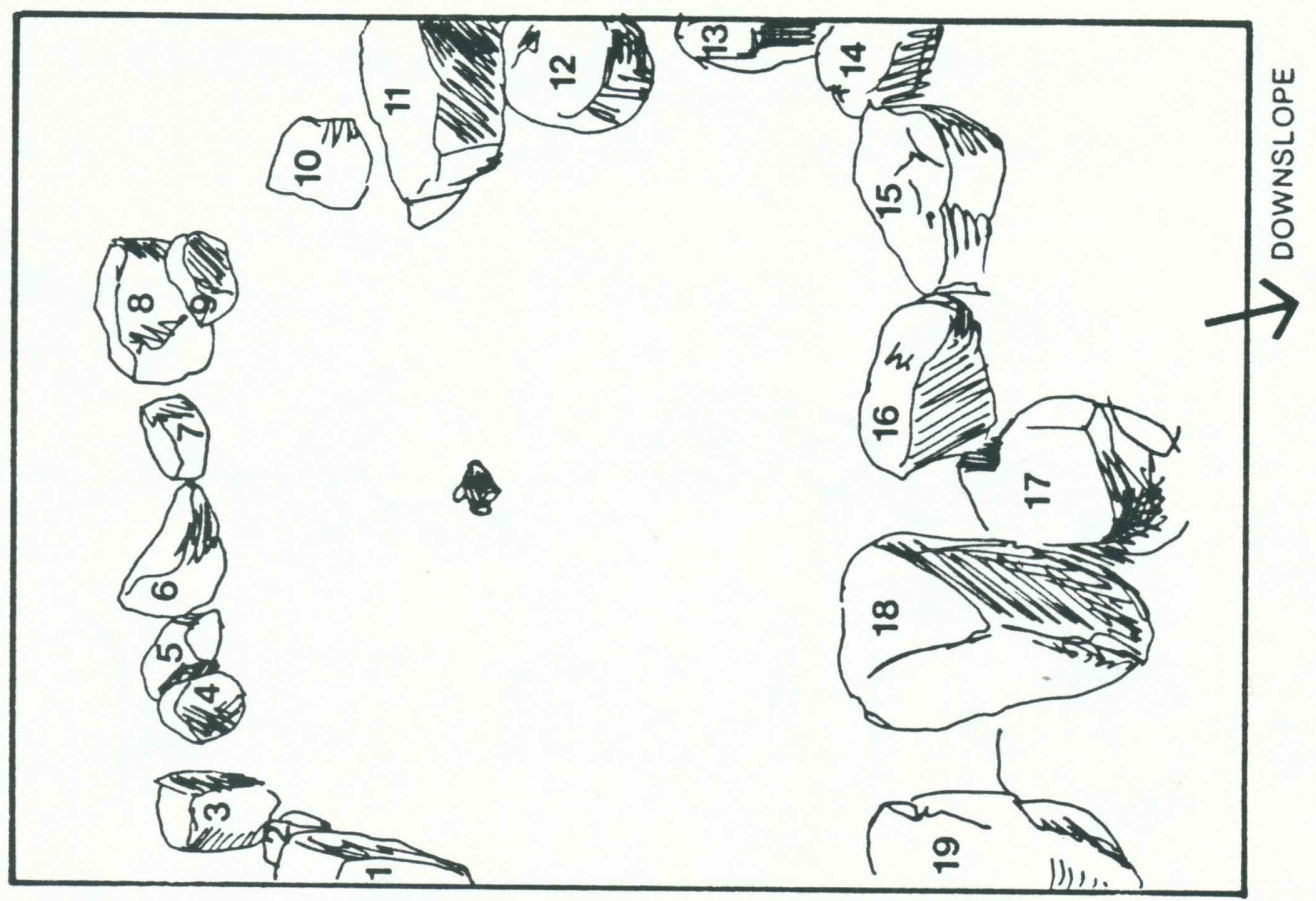

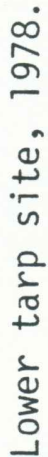

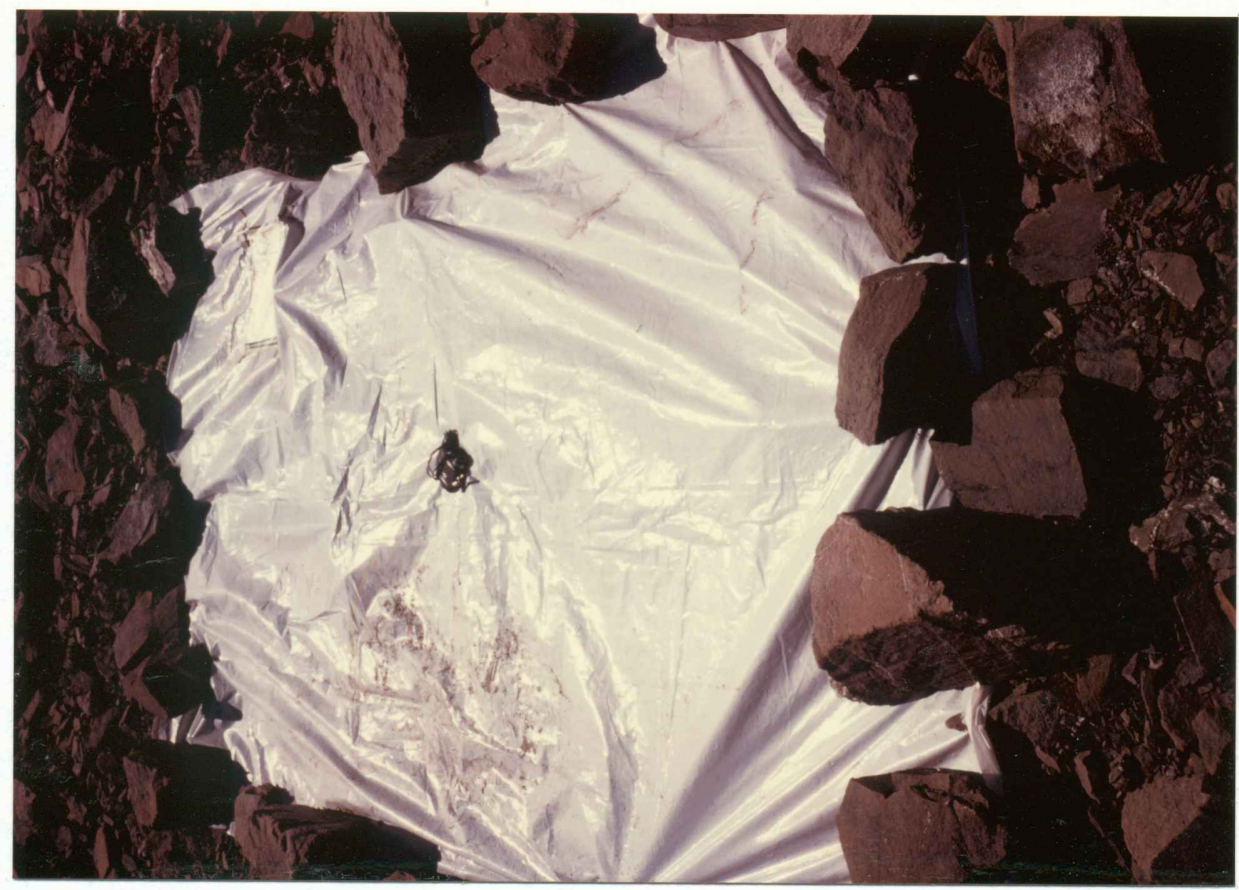

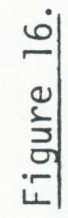




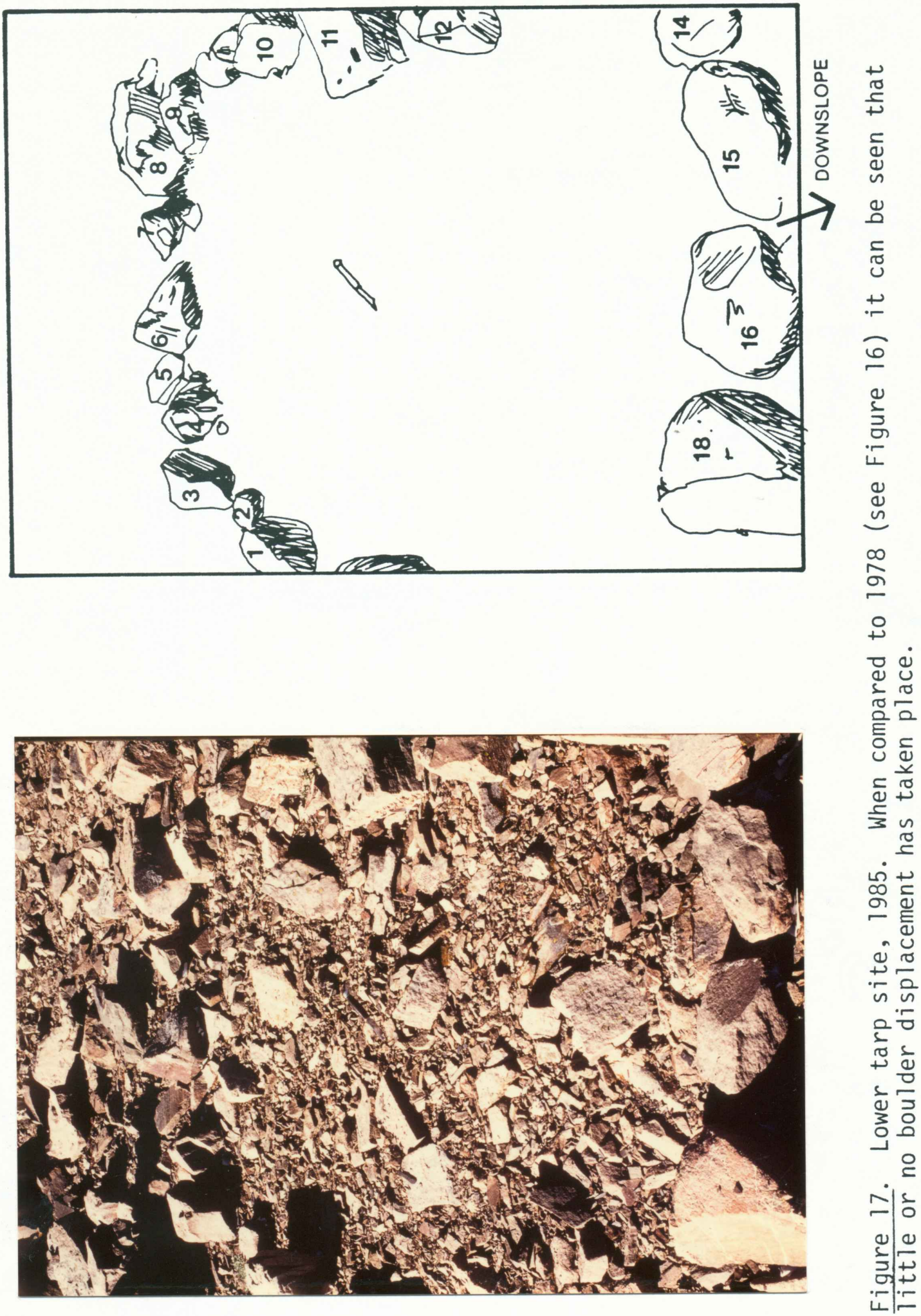


suggest that individual rockfall processes are operative, possibly in conjunction with downslope talus creep. It appears that the boulders marked 11,12 , and 13 may have been moved by impact from a cascading boulder, perhaps the unmarked boulder immediately adjacent to boulder 11 in the 1986 photograph. Note also the absence of boulder number 36 from the more recent photograph, illustrating the instability of surface talus boulders. The numerous smaller boulders which appear on the upslope border of the more recent photograph suggest an en masse shifting of the talus surface. The cause of this shifting may have been produced by the impact of a single boulder.

The eight year talus study suggests that there is very little activity of larger boulders near the base of the talus, but that some ongoing smaller debris accumulation occurs. The abundance of large boulders partially buried by finer debris at the talus base suggests that accumulation of the finer debris is presently more active than deposition of larger boulders. Even so, the lower talus is scattered with fresh angular boulders lying on the surface and on top of other boulders, indicating a continued, though limited, supply of rockfall material. Most of this debris is probably transported across the winter snow surface. Some of these boulders are undoubtedly transported beyond the talus base and onto the upper rock glacier surface. There does not appear to be any significant movement or flow of debris from the talus base to the rock glacier.

Midslope and upper slope talus processes are more readily affected by both rockfall and creeping talus, although rates of debris accumulation and movement still appear to be considerably less than 


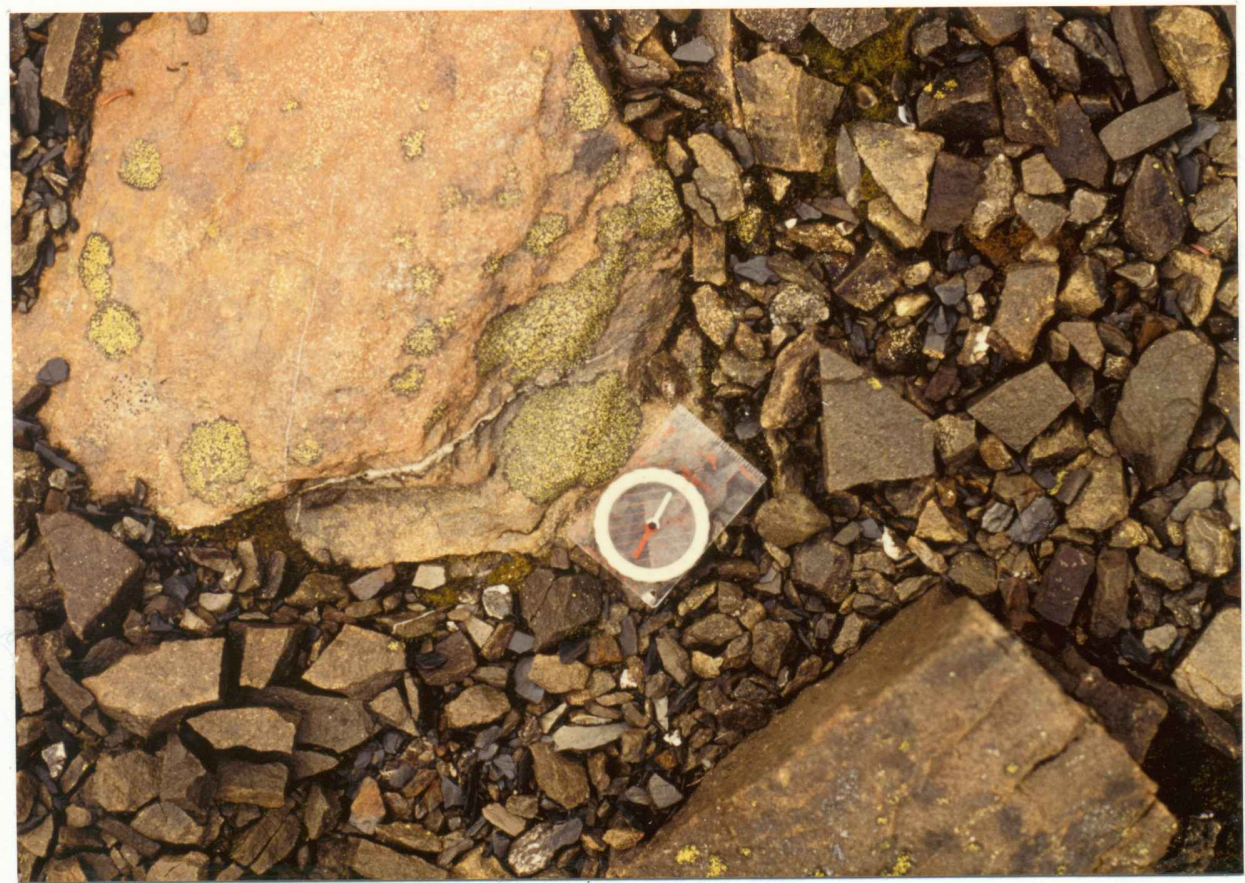

Figure 18. A large Rhizocarpon thallus on a boulder at the lower tarp site indicates a long period of talus stability. 

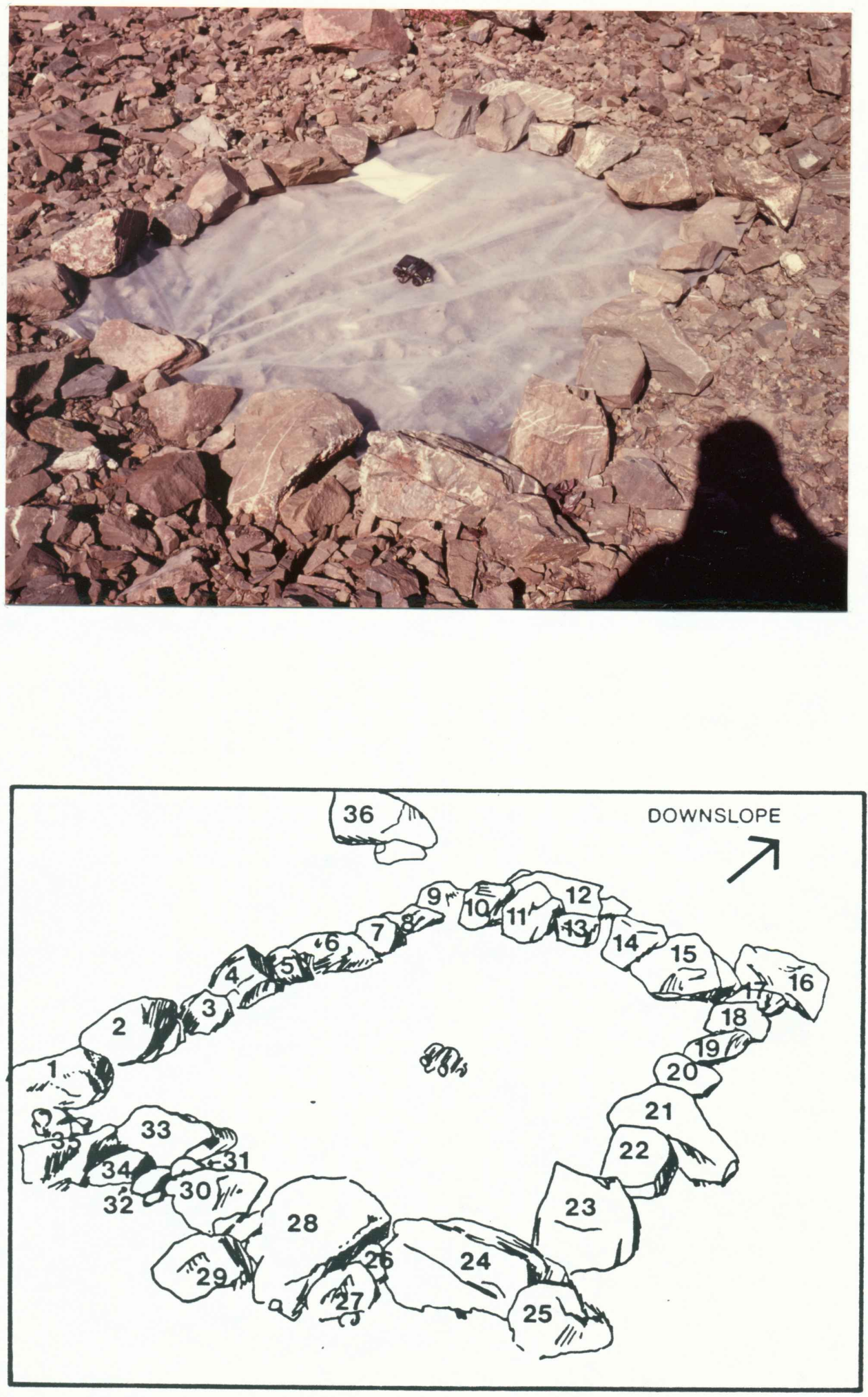

Figure 19. Middle tarp site, 1978. 

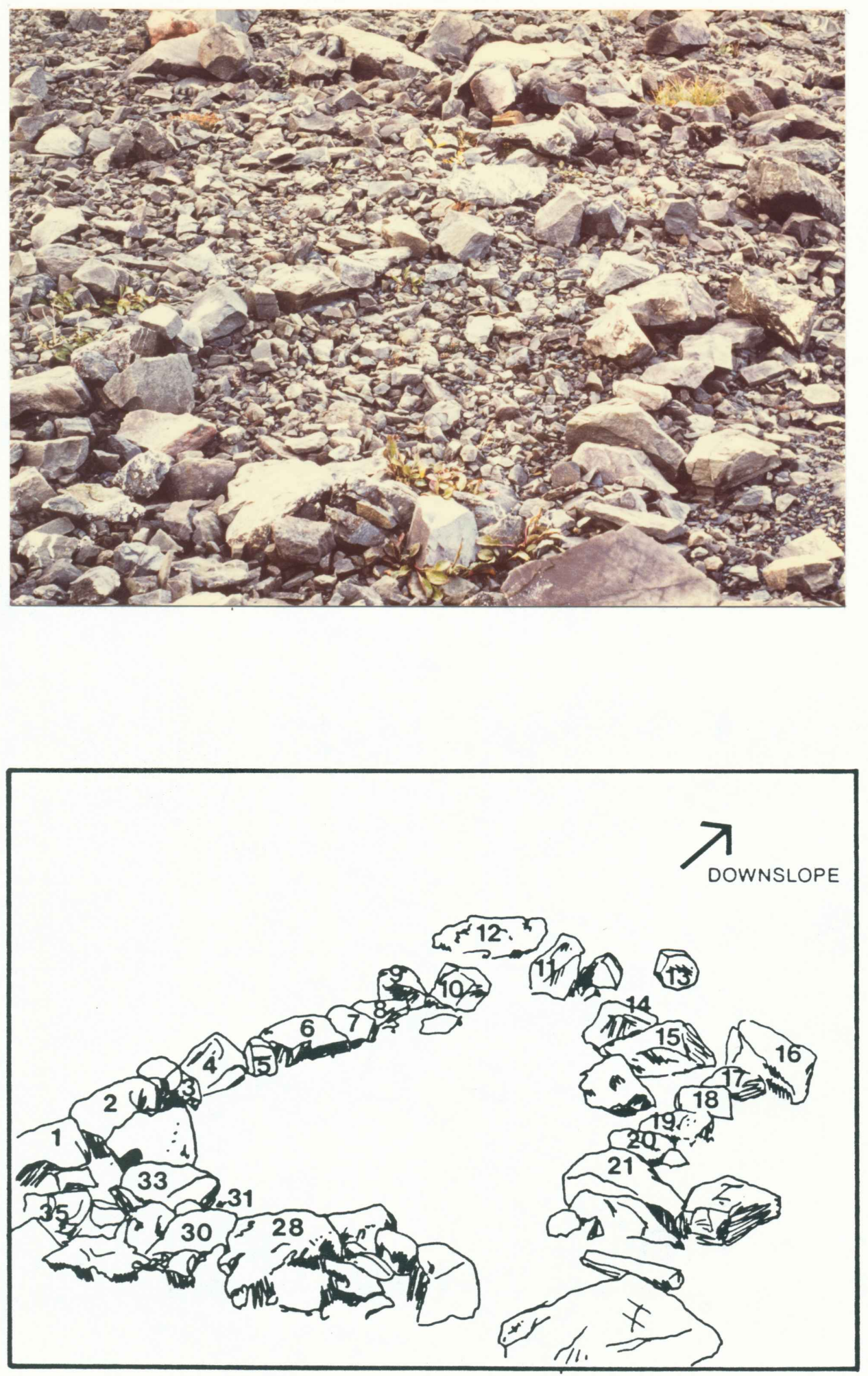

Figure 20. Middle tarp site, 1986. Some of the boulders have been displaced along the downslope border and there is an accumulation of new debris on the upslope border since 1978. 
active periglacial talus in other mountain areas (Rapp 1960, p. 172; Gardner 1973, p. 99). An assumption has been made that the talus areas have not been significantly affected by human or wildlife activities.

\section{AGE DATA}

\section{Tree Core Data}

Tree cores were taken from three subalpine fir (Abies lasiocarpa) on the rock glacier in order to determine the minimum length of time since stabilization of the rock glacier. Two samples were taken from trees growing on the toe; the third sample was taken from a tree on the upper lobe face (Figure 12). Growth-ring counts of the cores indicate that trees on the rock glacier reach ages of over 200 years (Table $V$ ). Since cores were taken $85 \mathrm{~cm}$ above the rock glacier surface it was necessary to adjust the growth-ring tally to account for the time it took for the trees to attain the $85 \mathrm{~cm}$ height. An estimated 65 years were added to each of the ring counts based upon a mean growth rate for subalpine fir of $0.77 \mathrm{~cm}$ per year in a forest-alpine ecotone (Hansen-Bristow and Ives, in progress). Nebert (1984, p. 18) reported two trees growing on the rock glacier with ages greater than 245 years. The presence of decayed logs on the rock glacier surface suggests that trees were established before the time indicated by living trees.

The age of trees growing on the rock glacier lobe faces indicate the minimum length of time since stabilization of these surfaces. Although an active rock glacier may have trees growing on its top surface (Giardino et a1. 1984, p. 299), lobe faces of active rock glaciers are too unstable to allow tree establishment. The data show 
TABLE $V$

AGE OF TREES GROWING ON AKELA ROCK GLACIER DETERMINED FROM GROWTH-RING COUNTS

\begin{tabular}{lccc}
\hline $\begin{array}{c}\text { Tree } \\
\text { Location }\end{array}$ & $\begin{array}{c}\text { Elevation } \\
\text { (meters) }\end{array}$ & $\begin{array}{c}\text { Number } \\
\text { of Rings }\end{array}$ & $\begin{array}{c}\text { Adjusted } \\
\text { Age }\end{array}$ \\
TC1 Lower Lobe Face & 1750 & 158 & 223 \\
TC2 Top of Lower & 1760 & 134 & 199 \\
$\quad \begin{array}{l}\text { Lobe Face } \\
\text { TC3 Upper Lobe Face }\end{array}$ & 1787 & 153 & 218 \\
\hline
\end{tabular}

that tree establishment on the upper lobe face occurred at approximately the same time as the lower lobe face, indicating that the growth-ring data are not useful in determining whether the upper lobe represents a significantly younger rock glacier advance. Stunted trees along the upper lateral ridges of the rock glacier were too small for tree core sampling.

Lichen Data

Lichens of the genus Rhizocarpon were measured on each of 50 boulders at each boulder site on the rock glacier (Figure 12). Although these yellow-green lichens were most probably Rhizocarpon geographicum, identification to species level was not possible in the field. It was assumed that lichens with the largest diameters were the oldest, and that percent coverage of lichens on boulder surfaces was indicative of age as well. Thus, boulders which have remained in place for the longest amount of time would tend to display the largest lichens and the most lichen coverage (Birkeland 1973, p. 404). The largest individual lichen thallus diameter on each boulder was measured to the nearest 
millimeter. Only lichens with approximately circular outlines were measured, and measurements were made in the direction of smallest diameter. Lichen cover was estimated for the exposed boulder face showing the greatest density of lichen cover. The amount of lichen coverage was classified as being either high (greater than $50 \%$ of the boulder surface covered with lichen), medium (between $10 \%$ and $50 \%$ coverage), or low (less than $10 \%$ coverage).

The results of the lichen survey are presented in Table VI. The largest Rhizocarpon thallus was found at Site Two and had a diameter measuring $57 \mathrm{~mm}$. Rhizocarpon coverage was most abundant on the lower part of the rock glacier at Site Three, where more than half of the boulders sampled displayed greater than 50\% coverage. Birkeland (1973, p. 408) has suggested that percentage coverage is a better indicator of age than is maximum diameter. Thus, Site Three appears to have stabilized earlier than the other two sites despite its not having the largest individual thalli. The proximity of Site Three to the lake, as well as the cool, shaded micro-environment provided by surrounding vegetation, may have favored lichen productivity at this location over the other two sites. Lichens are scarce on the surfaces of boulders in low-lying furrows and pits where snow tends to persist longer into the summer season; snow cover does not appear to have been a significant factor regarding lichen cover at the sample sites.

The high percentage coverage at Site Three made it difficult to differentiate individual lichen thalli, thereby preventing measurement of a representative maximum thallus. In contrast, lichen thalli growing at Sites One and Two were more dispersed and generally easy to 
differentiate. All boulders sampled at Sites Two and Three showed

\section{TABLE VI}

MAXIMUM THALLUS DIAMETER AND PERCENTAGE COVERAGE OF RHIZOCARPON FOR BOULDER SAMPLE SITES AT AKELA ROCK GLACIER

\begin{tabular}{|c|c|c|c|c|c|}
\hline & $\underset{(\mathrm{mm})}{\text { Max imum Diameter }}$ & $\begin{array}{r}\mathrm{Pe} \\
>50 \% \\
\end{array}$ & $\begin{array}{l}\text { centage } \\
10 \%-50 \% \\
\end{array}$ & $\begin{array}{r}\text { Coverage } \\
1 \%-10 \% \\
\end{array}$ & $\begin{array}{l}(\%) \\
\text { None } \\
\end{array}$ \\
\hline Site One & 40 & 20 & 52 & 18 & 10 \\
\hline Site Two & 57 & 20 & 42 & 38 & -- \\
\hline Site Three & 40 & 58 & 34 & 8 & -- \\
\hline
\end{tabular}

Sample size $=50$

some lichen growth, while $10 \%$ of the boulders at site One were lichen-free; the lichen-free boulders at Site One are attributed to relatively recent deposition through rockfall processes from the cirque headwa 11 and talus.

At present, no growth-curves have been established for the 1 ichens in the 0lympic Mountains. Numerous studies in mountains of the western United States have utilized lichens for dating glacial deposits. The results of these studies (Table VII) may be useful for estimating the age of lichens growing on surface boulders at Akela rock glacier.

Correlations of surficial deposits based on lichen data are suspect due to regional and microclimatic variations between sites, and only broad generalizations at best can be made from the data in Table VII. Lichens grow more slowly under cold, dry continental regimes than in maritime regions (Locke et al. 1979, p .28)(Table VII). Perhaps the nearest comparable site in Table VI to the northeast 0lympics is the 


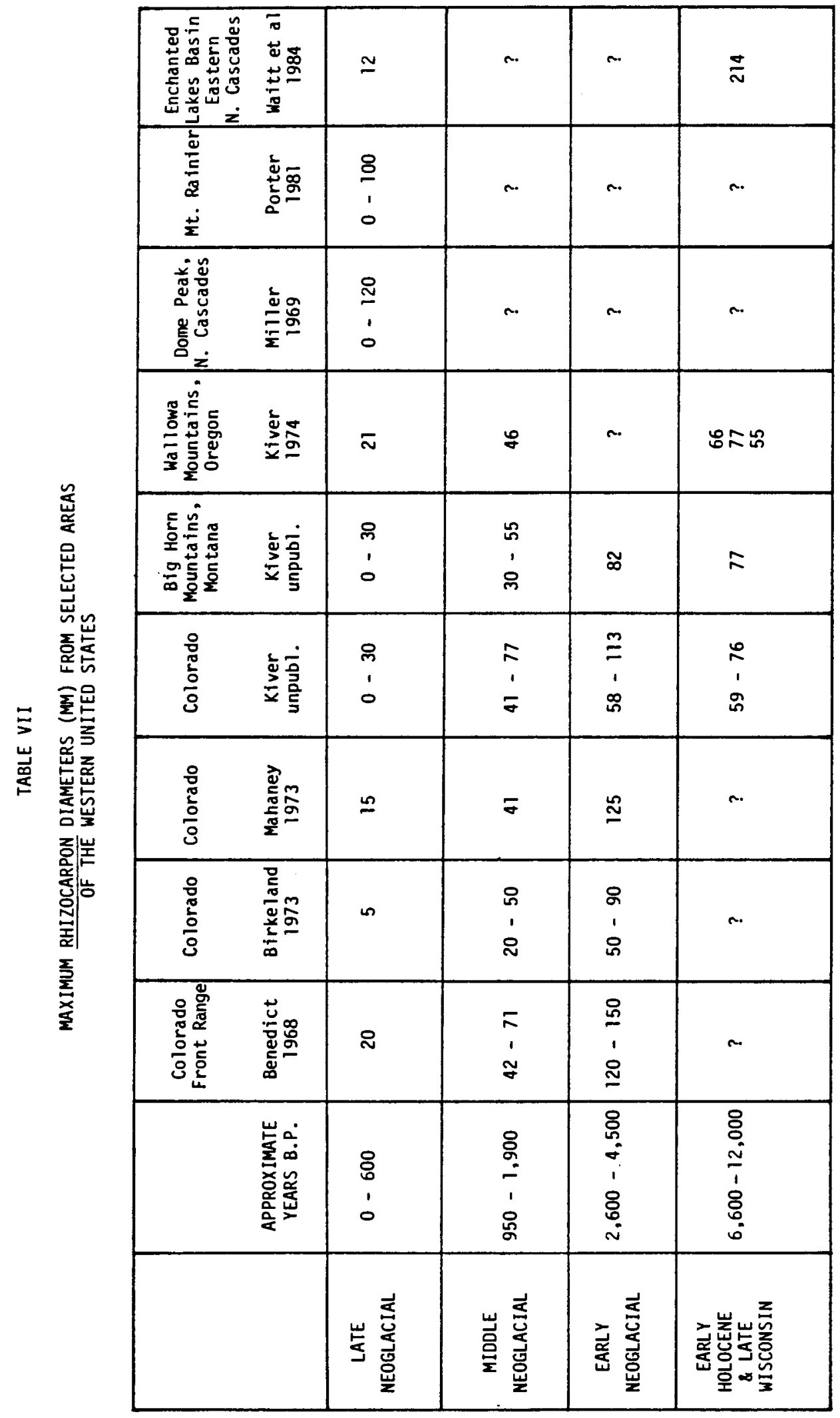


Enchanted Lakes Basin on the lee side of the North Cascades. Waitt et a1. (1982, p. 193) estimated a mean annual precipitation of $66.9 \mathrm{~cm}$ and mean annual tempe rature of $-0.4^{\circ} \mathrm{C}$ at Enchanted Lakes Basin; Gray Wolf Ridge is estimated to be more moist $(109 \mathrm{~cm})$ and slightly warmer $\left(1.2^{\circ} \mathrm{C}\right)$ based on climatic data for nearby Hurricane Ridge (Fonda and Bliss 1969, p. 286). Lichen data from Enchanted Lakes Bas in indicate that very recent Neoglacial moraine deposits display maximum Rhizocarpon diameters of $12 \mathrm{~mm}$; these moraines are estimated to have been deposited "within the last century" (Waitt et a1. 1982, p. 204). Based upon the meso-scale climatic estimates, growth rates would be expected to be slower at Enchanted Lakes due to less precipitation and lower temperatures. However, the significant difference in maximum thallus diameters between the recent Neoglacial deposits at Enchanted Lakes (12 $\mathrm{mm})$ and maximum diameters on Akela rock glacier $(57 \mathrm{~mm})$ suggest that Akela is older.

Most likely, the growth rate for lichens at Akela rock glacier is between the rates for the western Cascades and Rocky Mountains. If this is true, then the maximum lichen thallus of $57 \mathrm{~mm}$ found on Akela rock glacier would probably place it with in the Middle Neoglacial bracket (950 - 1,900 years B.P.) in Table VII. The lower lobe of the rock glacier may be this age or older, despite the fact that individual lichens were not as large as those on the upper lobe. It also suggests that the upper rock glacier surface (Site One) is younger, possibly late Neoglacial in age.

Boulder Weathering

Corner angularity was used as an index of boulder weathering. This 
relative age dating technique works under the premise that boulders recently deposited from the headwall will tend to display sharp-angled corners; with time, weathering processes tend to round the corners. Measurements of corner angularity were made at each of the three sampling sites in order to compare the degree of boulder weathering at different locations on the rock glacier surface. Boulders were classified as being either angular, subangular, or subround based on criteria outl ined by Birkeland (1982, p. 448). For each boulder, angularity of the most weathered edge facing the observer was estimated using an approximate radius of curvature of $<0.25 \mathrm{~cm}$ for angular, 0.25 to $2.0 \mathrm{~cm}$ for subangular, and $>2.0 \mathrm{~cm}$ for subround.

The results of the corner angularity data collected at the three boulder study sites (Figure 12) are given in Table VIII. The data indicate a regular progression towards more rounding of boulders from the upper rock glacier surface towards the base. The differences between Sites One and Three are particularly noticeable.

\section{TABLE VIII}

CORNER ANGULARITY DATA FROM BOULDER SITES ON AKELA ROCK GLACIER

\begin{tabular}{|c|c|c|c|}
\hline & Angular & Subangular & Subround \\
\hline Site One & $36 \%$ & $64 \%$ & -- \\
\hline Site Two & $16 \%$ & $84 \%$ & -- \\
\hline Site Three & -- & $90 \%$ & $10 \%$ \\
\hline
\end{tabular}

Birkeland (1973, p. 413) reported that boulder weathering may be useful in differentiating variably-aged surfaces on the same rock 
glacier. This appears to be the case at Akela rock glacier. The large percentage of angular boulders at Site One represent relatively recently deposited boulders, while the tendency for boulders to be more rounded at Site Three suggests a longer period of exposure to weathering. This is reinforced by the earlier finding that boulders tend to be smaller towards the base of the rock glacier.

\section{Soils Data}

Five soil pits were dug at various locations on the rock glacier (Figure 12, Sites $A-E$ ). The sites were located on ridgetops, where the slope was minimal and fine-grained matrix material was more abundant than the large open-work boulders in furrow areas on the rock glacier. Despite the relative abundance of fines, digging was extremely difficult due to the rockiness of the substrate. In addition, trees tended to be preferentially located in soil areas, and roots were frequently encountered while digging. Many potential sites were abandoned simply because it was impossible to dig deeper than 15 to $20 \mathrm{~cm}$. Often, the subsurface sandstone blocks were fractured in place, with the smaller, angular stones fitting together like pieces of a jigsaw puzzle. For the most part, subsurface boulders were less intact than those found at the surface.

Table IX summarizes the soils data, including data from two sites ( $F$ and $G$ ) located downvalley from the rock glacier; profiles are provided in Figure 21. Soils on the rock glacier are similar to each other, with only minor variations in color and texture. All sites consisted of structureless, very stony, sandy loam (Figure 22). Some of the variability recorded in soil color may be attributed to the 


\begin{tabular}{|c|c|c|c|c|c|c|c|c|c|}
\hline \multirow{5}{*}{\multicolumn{2}{|c|}{ 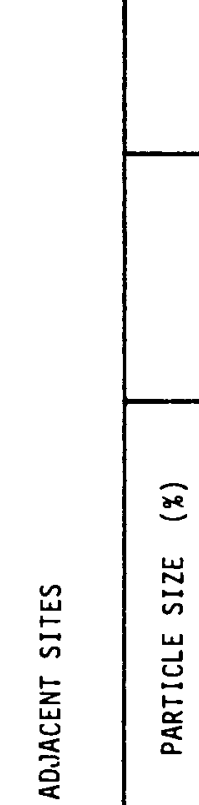 }} & $\begin{array}{l}\text { 容 } \\
\text { 产 } \\
\text { 总 }\end{array}$ & 㫕 & $\stackrel{\text { go }}{\frac{0}{2}}$ & 岌 & $\stackrel{\mathscr{\nu}}{\frac{0}{2}}$ & $\stackrel{0}{\stackrel{0}{0}}$ & $\stackrel{0}{\check{0}}$ & 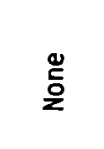 \\
\hline & & $\begin{array}{l}\text { 訔 } \\
\text { 扂 }\end{array}$ & 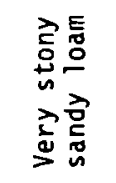 & 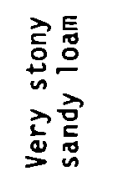 & 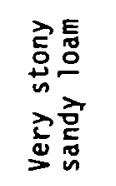 & 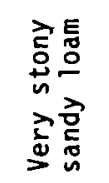 & 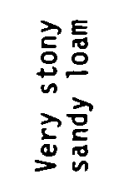 & 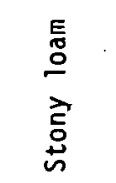 & 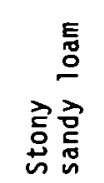 \\
\hline & & $\frac{\pi}{0}$ & \pm & $\simeq$ & $\stackrel{n}{ }$ & $\stackrel{\infty}{\infty}$ & \pm & $\approx$ & $\stackrel{2}{\sim}$ \\
\hline & & $\frac{ \pm}{i n}$ & 尺 & 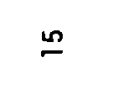 & $\approx$ & ㅇ్ల & $\approx$ & $\approx$ & $=$ \\
\hline & & $\begin{array}{l}\text { D } \\
\text { 心 }\end{array}$ & $\mathscr{0}$ & $\stackrel{m}{\sim}$ & $\tilde{\sigma}$ & กี & 옹 & $\bar{\sigma}$ & 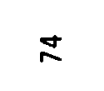 \\
\hline \multirow{7}{*}{ 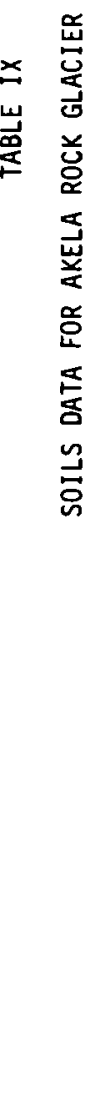 } & \multirow{2}{*}{$\begin{array}{l}\text { z․ㅠ } \\
\text { : } \\
\text { 오 } \\
\infty\end{array}$} & 흥 & 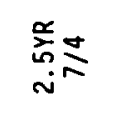 & 옹응 & 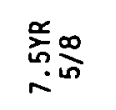 & 옹으 & 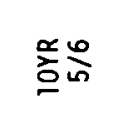 & 옹 & 产员少 \\
\hline & & 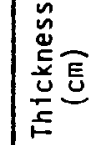 & $\bar{\sim}$ & $\frac{\infty}{\dot{m}}$ & $\overline{\mathfrak{v}}$ & $\bar{b}$ & $\frac{\infty}{\dot{m}}$ & 足 & 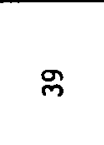 \\
\hline & \multirow{2}{*}{ 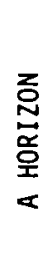 } & 흥 & 高ミ & 중슴 & 옿ำ & 옹ำ & 옹 & 옹히 & 彥す \\
\hline & & 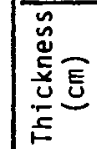 & $\forall$ & $n$ & $\theta$ & $\frac{\pi}{5}$ & - & 으 & $=$ \\
\hline & \multicolumn{2}{|c|}{ 岂 } & 욤 & $\stackrel{9}{g}$ & $\begin{array}{l}\equiv \\
\overline{8} \\
8\end{array}$ & ఇ్ & $\underset{\Phi}{\Phi}$ & $\underset{I}{ \pm}$ & 怘 \\
\hline & \multicolumn{2}{|r|}{ 吕 } & 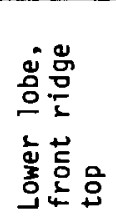 & 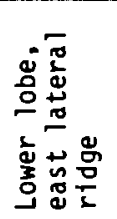 & 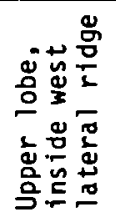 & 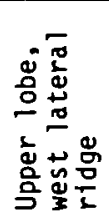 & 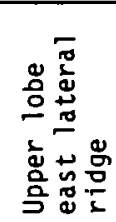 & 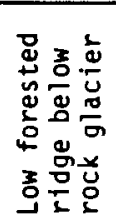 & 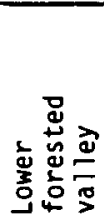 \\
\hline & \multicolumn{2}{|r|}{$\stackrel{\omega}{\leftrightarrows}$} & $\alpha$ & $\infty$ & ט & 0 & w & 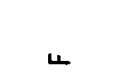 & ט \\
\hline
\end{tabular}




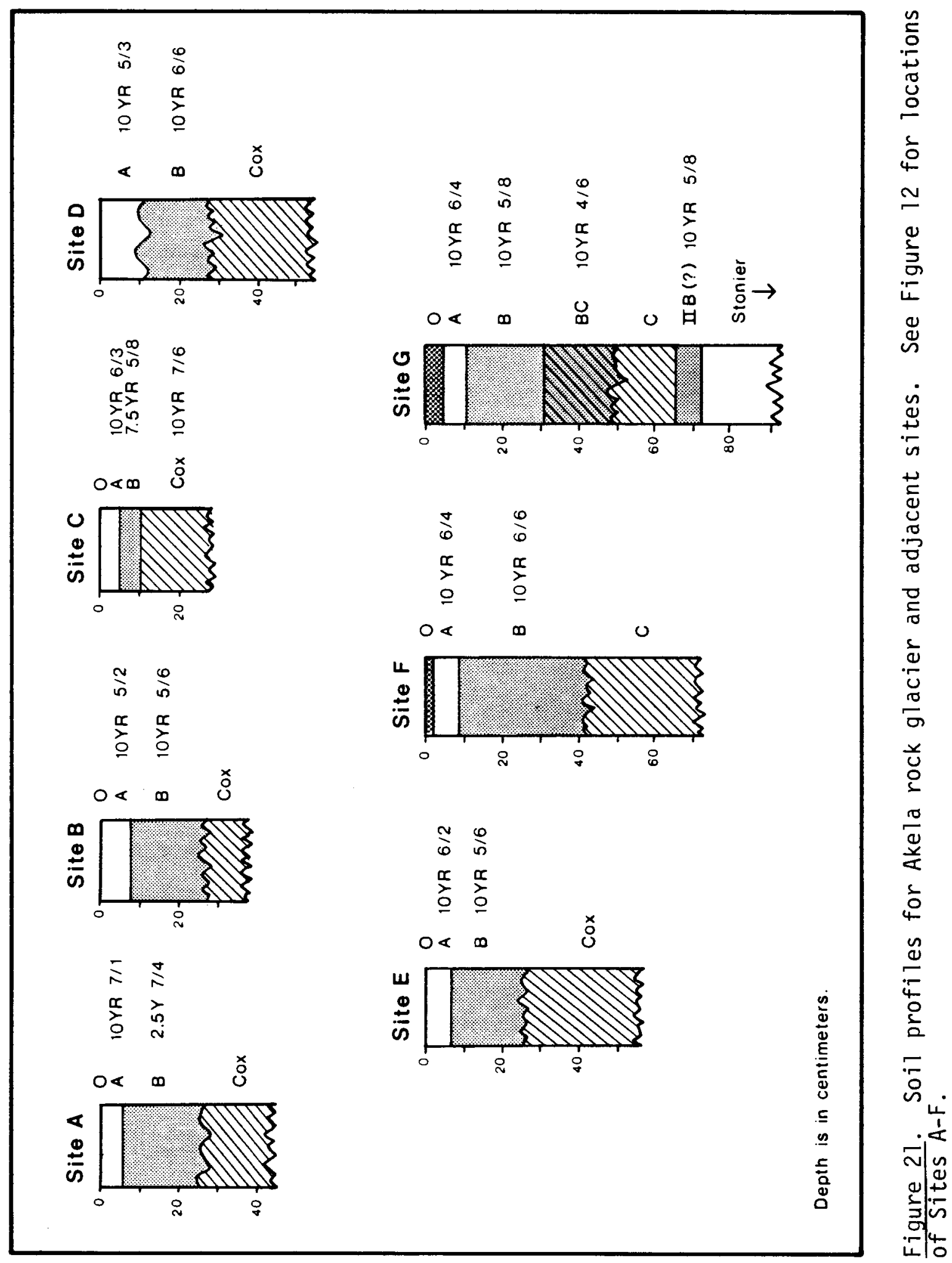


presence of dark gray to light brown pebbles and sand-sized particles which often conflicted with the color of the matrix.

All of the sites, except site $D$, displayed a thin $(0.50$ to $1.25 \mathrm{~cm})$ organic horizon. Most $A$ horizons varied in width from four to seven $\mathrm{cm}$, while colors ranged from light gray (1OYR 7/1) to light brown (1OYR $5 / 3)$. The transition between the $A$ and $B$ horizons tended to be abrupt to clear, and irregular to broken due to the many large stones present.

B horizons were designated strictly by color since no textural or structural differences were evident in the field between the $A$ and $B$. Below the $A$ horizon all fine-grained material tended to have higher chroma values, indicating translocation and deposition of iron. The zone of greatest accumulation tended to occur between depths of about 20 and $25 \mathrm{~cm}$. No clear distinction could be made between the $B$ horizon and an oxidized $C$ horizon $\left(C_{0 x}\right)$. Therefore, the $C_{0 x}$ was approximated to occur below the $25 \mathrm{~cm}$ level.

The well-delineated color difference between the $A$ and $B$ horizons verifies that soil formation has been occurring on the rock glacier, al though the amount of time is not easy to assess. The pale A horizon and darker $B$ horizon have characteristics of a poorly developed or incipient Spodosol which, under ideal conditions, would take at least a few hundred years to develop (USDA 1975, p. 29). The well-drained substrate and coniferous vegetation would tend to favor podzolization, but the severity of the alpine environment would inhibit rapid soil development.

It is not known how long it would take the rock glacier surface to accumulate the surficial fines upon which the soil has developed. The 


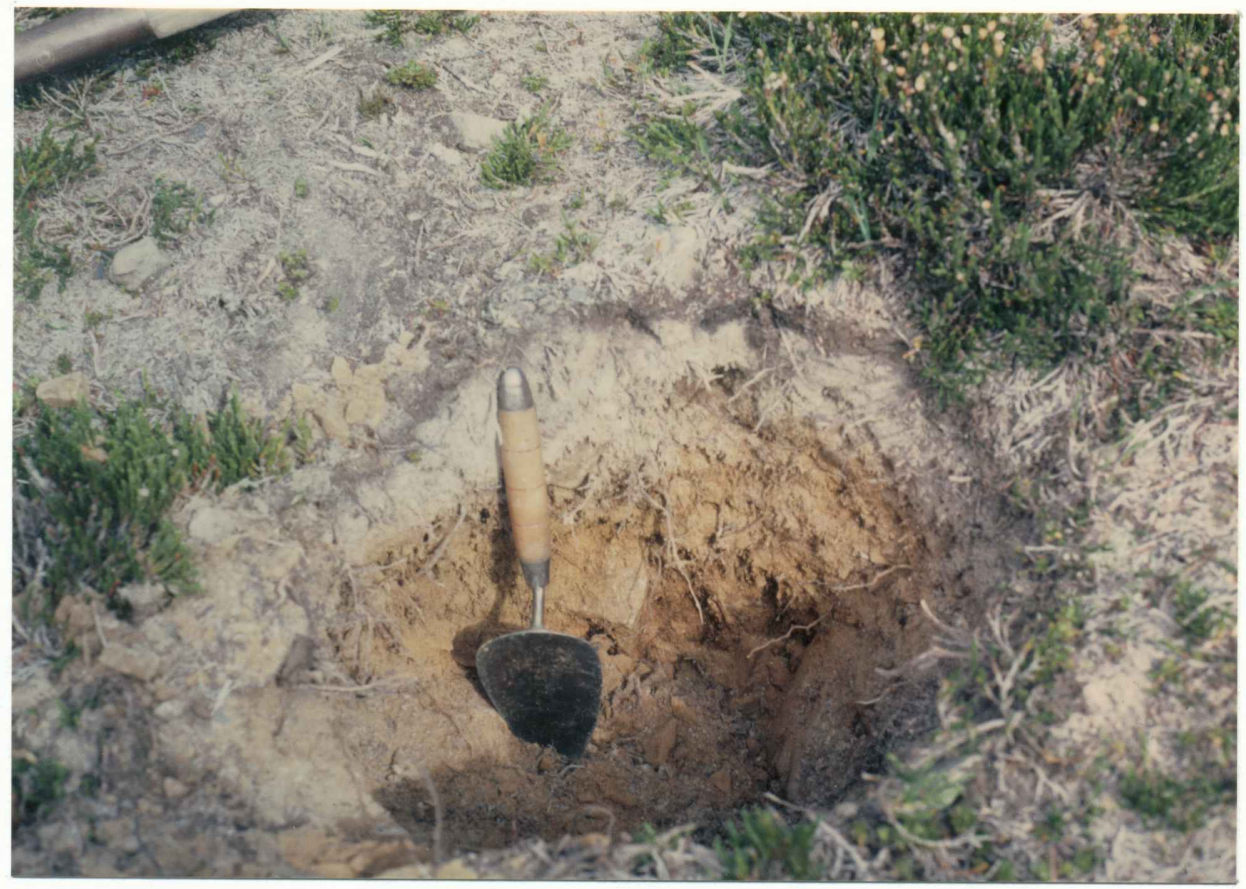

Figure 22. Soil profile at Site $E$ on Akela rock glacier illustrates a Spodosolic profile. 
predominance of sand-sized particles indicates that most of the matrix material has been locally derived rather than wind-transported. Trees and other vegetation have undoubtedly aided in soil development by penetration of the subsurface by roots which aid in the breakup of boulders and help in the retention of fines. However, the soils appear to be older than the $200+$ years of the oldest trees growing on the rock glacier. Several hundred years or more must have passed in order for the soil to develop; additional time would be needed for the weathering and accumulation of the fine matrix. Strangely, there does not appear to be a distinct difference between the upper and lower rock glacier ridge-top surfaces in terms of soil development. This suggests that the lateral ridges along the upper rock glacier surface are probably similar in age to lower surface ridges, and that the upper lateral ridges have remained relatively stable, while most of the rock glacier flow was focused towards the center of the feature.

Birkeland (1973, p. 412) found that soils were useful in differentiating rock glacier deposits of Neoglacial age from those of Late Pleistocene age in the Colorado Rockies; however, he was unsuccessful in differentiating between Neoglacial deposits of different ages. I dug two soil pits downvalley from the toe of the rock glacier (Figures 12 and 21 , Sites $F$ and $G$ ); one was located on the low forested ridge across the lake from the rock glacier; the other was located more than $100 \mathrm{~m}$ lower in elevation, in the forested valley below the rock glacier. Because of their topographic relationship with the rock glacier, I expected these sites to show greater soil development than the rock glacier sites. 
At both of the downvalley sites, soils were developed in a pebbly diamicton that was less stony than on the rock glacier sites. A horizons were slightly deeper than the rock glacier sites; $B$ horizons were also deeper, and more thoroughly oxidized. Neither of the downvalley sites showed signs of soil structure or clay accumulation in the $B$ horizon; however, based on the depth and degree of oxidation, these sites appear to be older than the rock glacier soils.

\section{Meadow Stratigraphy}

A large pit was excavated in the wet meadow area northwest of the rock glacier toe, approximately six meters south of the shallow pond (Figure 12). A stratigraphic column reconstructed from field observations reveals a complex depositional history at the site (Figure 23). Radiocarbon dates for three separate layers of organic material provided age markers for the column. The organic material was radiocarbon dated by the Quaternary Research Center Isotope Laboratory at the University of Washington.

The lowest layer of the profile consisted of coarse, angular poorly-sorted debris in a matrix of silty clay. This diamicton may represent a ground moraine left by the last Pleistocene glacier to occupy the cirque. The depth of the diamicton was not determined due to problems of groundwater seeping into the pit. The dense, sticky organic-rich clay which overlies the diamicton probably represents sediments deposited in a lake or pond larger than the one which now occupies the lower half of the meadow.

The stony layer which occurs at a depth of 55 to $66 \mathrm{~cm}$ may be a very late Pleistocene or early Holocene glacial deposit, but this seems 


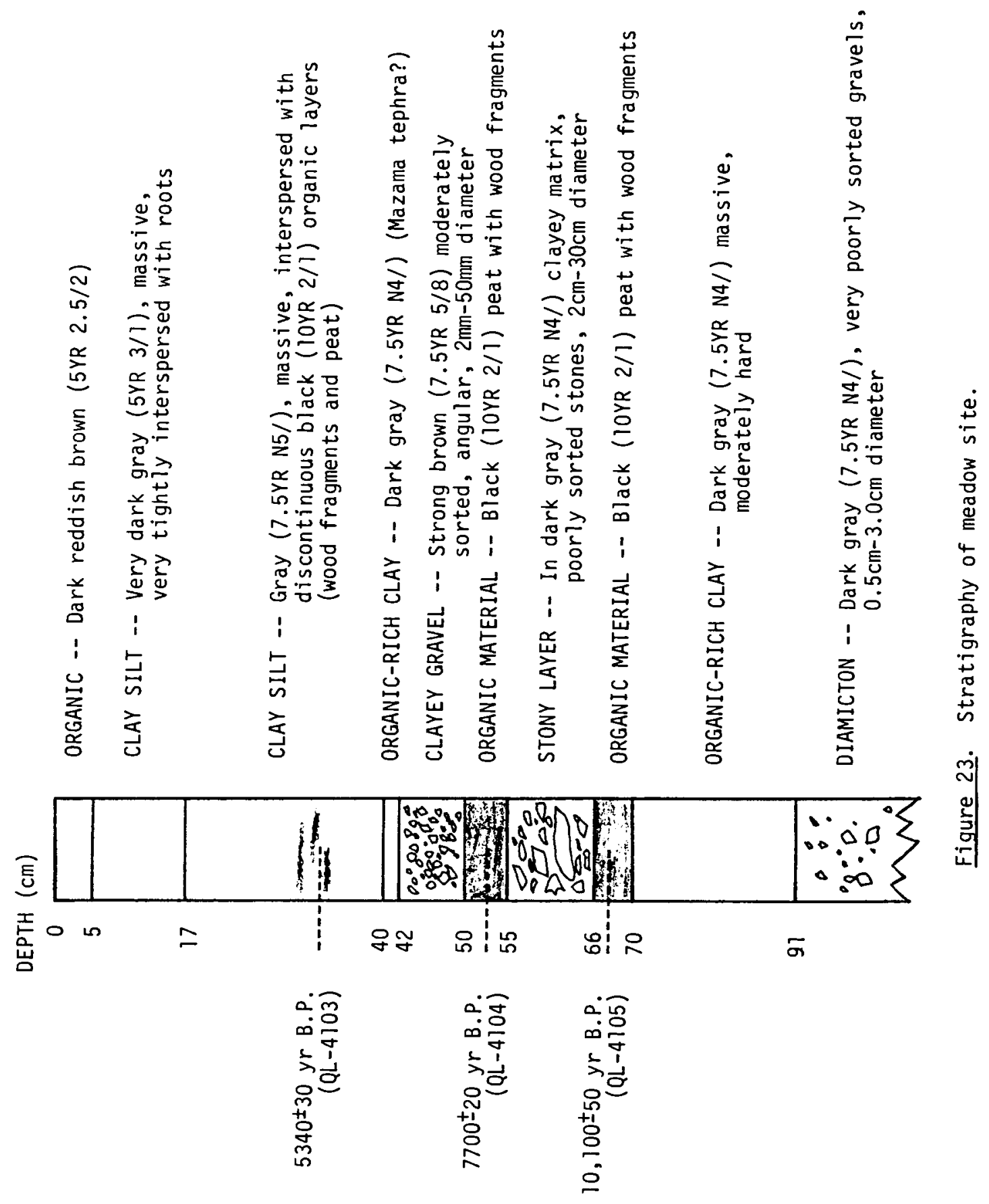


improbable given the general lack of supporting evidence for such an advance. More likely, the rocky layer is due to rockfall or debris avalanche originating on the slope to the west. The gray, clayey matrix interspersed with in the stones indicates that the debris was either deposited into a lacustrine environment similar to that which produced the lower clay unit, or that a later period of submergence allowed finer sediments to settle into the open spaces between the stones. The organic layer beneath the stony unit may represent vegetation carried downslope by avalanche, or perhaps it represents a meadow similar to that which exists now.

The clayey gravel overlying the organic layer dated at 770020 years B.P. consists of moderately sorted angular clasts of sandstone and shale within a silty clay matrix. Again, the clayey matrix indicates submergence either at the time of deposition or sometime afterward. This layer lies at the water-table level; its color (7.5 YR 5/8) indicates translocation of iron. The origin of this gravelly layer may be colluvial material brought down from adjacent slopes by soil creep or solifluction. A narrow clayey horizon at the $40 \mathrm{~cm}$ depth overlies the gravel deposit. Originally, this thin band of clayey sediment was simply viewed as a lacustrine deposit, but the bracketing radiocarbon dates of 7,700 and 5,340 years B.P. suggest that the clay horizon may be a Mazama tephra unit. Unfortunately, I did not collect samples for laboratory examination.

Beginning approximately 6,000 years ago the meadow site began to accumulate the clay silt which makes up the upper $40 \mathrm{~cm}$ of the stratigraphic column. The lower part of the gray (7.5YR N5/) clay silt 
unit exhibits discontinuous layers of organic material. The gray color, as in the lower clayey deposits, is believed to represent oxygen reduction caused by poor aeration. The organic material is probably derived from trunks and limbs of trees brought downslope by snow avalanching. No buried organic material was evident above the $17 \mathrm{~cm}$ level. It appears that fine sediments have been accumulating at the meadow site with no significant input of coarse debris for the past 6,000 years. This precludes the possibility of an early Neoglacial glacier advance, and suggests that the debris which constitutes Akela rock glacier began to accumulate following the demise of the last Pleistocene glacier at this location.

The rock glacier itself probably contributed only fine sediments to the meadow site, with the small pond slowly becoming infilled by sediments carried in suspension by the small stream issuing from the base of the rock glacier. Previous researchers have reported that rock glaciers act as sieves in screening out coarser debris carried in subsurface channels, creating low sediment yields in comparison to true glaciers (Potter 1972, p. 3051). 
CHAPTER VI

FORMATION AND AGE OF AKELA ROCK GLACIER

FORMATION PROCESSES

Before discussing the probable mechanisms involved in the formation of the Akela rock glacier, two alternative modes of origin are considered -- deposition as a glacial moraine and deposition as a catastrophic rockfall (sturzstrom). Morphological characteristics of the Akela rock glacier oppose its interpretation as a morainal deposit. Although end moraines may vary greatly in form (Sugden and John 1976, pp. 234-35), most terminal alpine glacial moraines display a convex-downslope ridge form somewhat similar to the lower frontal lobe of the rock glacier. However, the Akela rock glacier deposit extends more or less continuously from its toe to the talus base (Figures 9 and 12). The terminal moraine of a glacier would be disconnected from its source area by glacial ice or the area once occupied by glacial ice. Although glacial moraines often exhibit multiple ridges, the complex surface topography of transverse and longitudinal ridges and furrows, pits, and lobes strongly favors a rock glacial origin of formation. Furthermore, the lack of coarse outwash sediments beyond the toe of the deposit is consistent with the findings of others regarding the nature of rock glacier outwash (Washburn 1980, p. 231).

The notion that this deposit may have originated as a catastrophic rockfall (sturzstrom) does not apply either. Sturzstrom deposits may be 
confused with morainal or rock glacial deposits (Porter and Orombelli 1980, Butler 1984); they are commonly composed of coarse debris, and somet imes exhibit convex downslope ridge and furrow topography. Characteristics of catastrophic rockfall deposits which are inconsistent with the Akela rock glacier include the presence of a prominant headwa 11 scar, indicating the source area of the deposit; rock structures with weak lithologies dipping steeply toward the area of deposition; very little relief from head to toe of the deposit; and a low surface gradient compared to glacial deposits (Butler 1984, p. 341). No prominent headwall scar is evident above Akela rock glacier, and the headwall bedding dips away from the deposit, rather than toward it. In addition, the rock glacier exhibits a fairly steep surface gradient, rising approximately $100 \mathrm{~m}$ over a distance of about $400 \mathrm{~m}$.

The form and character of the Akela rock glacier and its immediate environs are consistent with rock glaciers described in the literature. The abundance of trees, vegetation, and lichens on both the upper and lower lobe fronts suggests that neither lobe is now active. Further evidence of inactivity includes the rounded angle of intersection between the rock glacier front and its upper surface, the prevalence of fine-grained surface material, and the lack of an abundant debris supply being provided by the headwall and talus above the rock glacier. The exact formation processes of this rock glacier are difficult to portray because of its inactive state; however, there must have formerly been an abundant source of debris from the upper cirque, with temperatures sufficiently cold to preserve an ice core/matrix with in the rock glacier. 
Under colder and possibly snowier conditions a small glacier or perennial snowfield would have occupied the upper cirque. It is likely that the debris which now constitutes the rock glacier was formerly a moraine or protalus deposit at the base of that snowfield/glacier. Pre-existing talus deposits together with a continued supply of rockfall detritus were transported downslope to the upper threshold area. The heavily-riven face of the cirque headwall suggests the work of avalanches as debris transporting agents. Wet spring avalanches are particularly effective erosive agents and would provide concentrated lenses of ice within the accumulation of debris at the base of the upper cirque. The deposit would then contain ice and snow from any or all of the following: snowbanks, glacial ice, avalanche snow, wind-drifted snow, and interstitial ice derived from refreezing of melted snow with the aid of Balch ventilation. When a critical mass of debris and ice accumulated at the upper threshold, it began to deform and flow downslope. Upon reaching the lower bas in floor, the rock glacier spread laterally in response to the lowered gradient. The two-lobed morphology of the rock glacier suggests that a second phase of activity occurred.

The question as to whether the rock glacier was ice-cemented or ice-cored cannot be answered at present, but it seems likely that multiple processes were responsible for ice accumulation, including the formation of interstitial ice. The several furrows and pits on the rock glacier surface suggest the former presence of ice-rich lenses within the rock glacier mass. The frozen lenses of massive ice and matrix of interstitial ice which allowed the rock glacier to flow meet the definition of permafrost as surface or subsurface material that has 
remained continually below freezing for two or more successive years (Muller 1947, p. 3; Barsch 1978, p. 349-50).

Although climatic causes (particularly warming temperatures) were undoubtedly important determining factors in the stagnation of the rock glacier, the lack of a continued and abundant debris supply from the headwall and talus areas was probably a contributing factor as well. It has been shown that under present conditions there is very little talus activity, particularly in the lower talus reaches. In addition, the boulder orientation at the head of the rock glacier suggests that surface sediments at the head have not undergone downslope movement, but are predominantly the result of depositional processes. The shallow, severely-eroded headwall is undoubtedly much less extensive than in previous times and can no longer provide ample quantities of sandstone boulders. The upper and midslope sections of the talus, though still active, are composed of predominantly finer clasts which tend to settle into and fill the open interstitial spaces of the larger blocks. As the headwall and talus areas became less geomorphically active over time, the debris supply to the rock glacier diminished and the rock glacier became less integrated with its source area.

\section{CHRONOLOGY OF ROCK GLACIER FORMATION}

According to Burke and Birkeland (1983, p. 5), rock glaciers, although difficult to date, may be placed within broad age classes correlative with glacial advances. They noted, however, that rock glacier responses to $c l i m a t i c$ changes are less sensitive than glaciers and that rock glaciers may have multi-age characteristics. Table $X$ 
lists the principal stratigraphic names and correlation of Holocene glacial deposits from major studies in the 01 ympic and North Cascade Mountains. The following discussion presents a brief statement of Pleistocene glacial activity in the study area, followed by an interpretation of the Holocene history of Akela rock glacier.

\section{Pleistocene}

Recent studies have indicated that Pleistocene alpine deglaciation in the North Cascades occurred by 11,250 years B.P. or earlier (Barnosky 1984, p. 625 ; Beget 1984, p. 304). No record exists for the $01 y m p i c$ Mountains, but fossil pollen from adjacent lowlands near Sequim suggests there was a warm, dry period in the 0lympic rainshadow between 11,000 and 12,000 years B.P. (Petersen et a1. 1983, p. 215). Most of the Pleistocene ice was probably out of the cirques in the northeast 0lympics by this time, if not sooner. The meadow stratigraphy below Akela rock glacier (Figure 23) suggests a prolonged lacustrine environment prior to about 10,000 years B.P., preceded by the last Pleistocene glacial event in this alpine cirque. Hence, the stratigraphic evidence appears to be in agreement with the rest of the Pacific Northwest record.

Surficial deposits from the last glaciation are not obvious in the Akela cirque basin. Most of the debris entrained by the glacier must have been carried over the steep cliff at the lip of the cirque bas in. The steep, narrow, v-shaped morphology and absence of truncated spurs in the lower valley suggests that the glacier terminated not far beyond the cliff. Instead of leaving recognizable morainal deposits, the glacier scattered till across the lower valley floor where it has become covered 
TABLE $X$

PRINCIPAL STRATIGRAPHIC NAMES AND CORRELATION OF HOLOCENE GLACIAL DEPOSITS IN THE CASCADE AND OLYMPIC MOUNTAINS, WASHINGTON

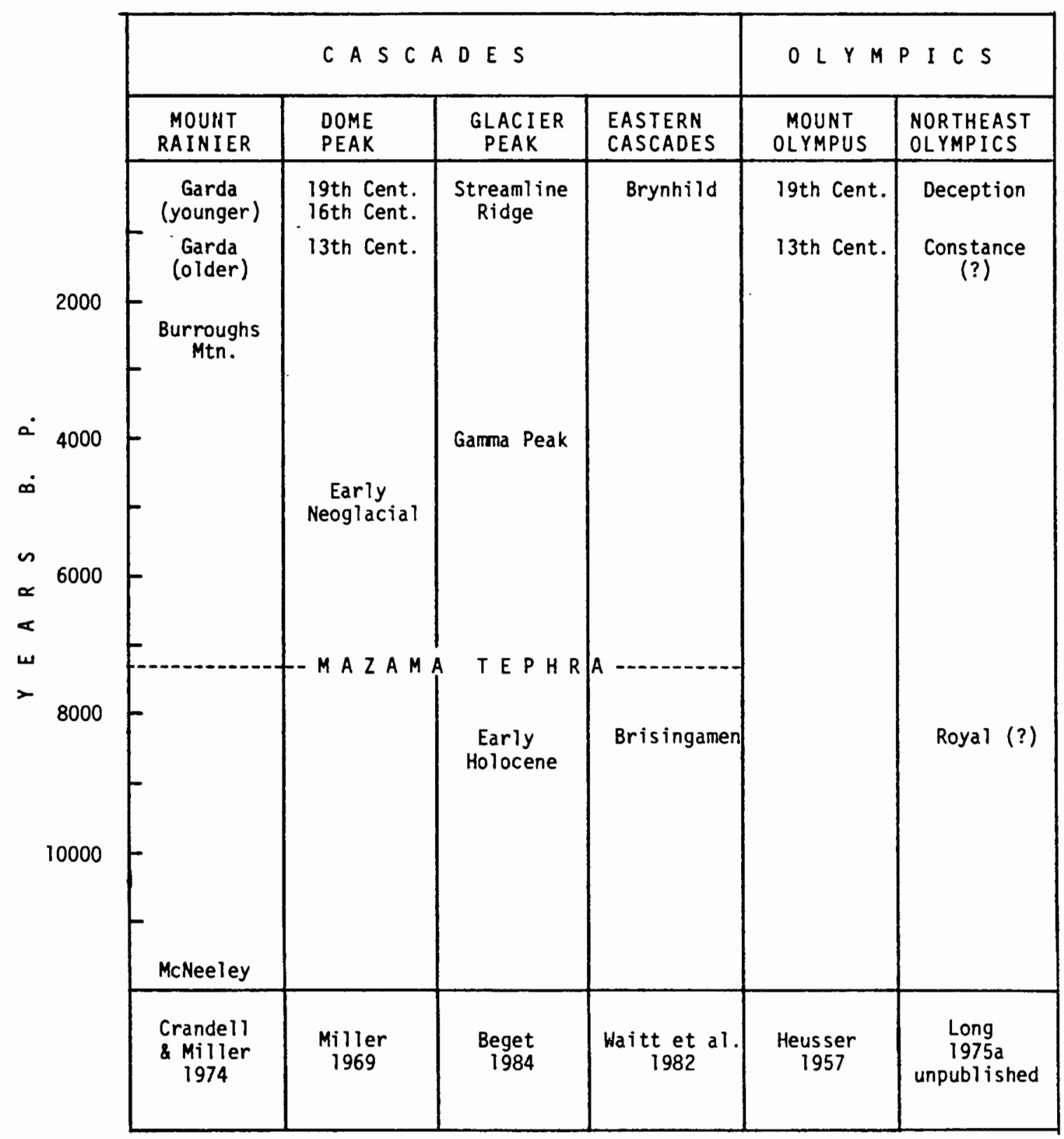


by mass-wasted slope deposits and obscured beyond recognition by subalpine forest. Soil development at the two sites beyond the terminus of the rock glacier (Table $I X$, Sites $F$ and $G$ ) indicates a greater age for these deposits than for the rock glacier. The tendency for the profile at Site $G$ to become more rocky with depth may depict a transition between colluvium and glacial till (Figure 21).

A few erratic boulders were found perched on the bedrock ridge just beyond the rock glacier terminus; the local topography strongly suggests that these boulders were glacially deposited. Striations, chattermarks and other erosional signs of glaciation were not found on any bedrock or boulder surfaces with in the Akela basin, although they are in nearby recently glaciated basins.

\section{Holocene}

There is strong evidence for an early Holocene glacial advance in parts of the North Cascades (Table $X$ ), but there are no reports of such an advance in the 0lympics. It is possible that an advance in the Royal Bas in of the northeast 0lympics reported by Long as either late Pleistocene or early Neoglacial may correlate to this period (Long 1974, p. $15 ; 1975 a, p .8)$. The best evidence for distinguishing between early Neoglacial and early Holocene/late Pleistocene deposits is the presence of the Mazama tephra unit (approximately 6,700 years old). Unlike other mountains in the Pacific Northwest, there has been no documentation of Mazama tephra in the 01ympics despite the fact that the 01ympics are with in the Mazama tephra plume (Porter 1981, p. 142). Future investigations in the 0lympic Mountains should be able to use this stratigraphic marker to aid in differentiating the ages of glacial 
deposits. The clayey layer found at a depth of 40 to $42 \mathrm{~cm}$ at the meadow site (Figure 23) probably represents the Mazama tephra. No evidence of Mazama tephra was found on the Akela rock glacier, suggesting that the feature is less than 6,700 years old.

Stratigraphic evidence from the meadow below Akela rock glacier suggests that no glacial advance has occurred in the lower cirque bas in with in the past 10,000 years. Therefore, Akela rock glacier represents the accumulation and movement of debris throughout the entire Holocene period. The possibility exists that an early stage of rock glaciation occurred during the early Holocene, although age data gathered from the rock glacier do not indicate this. If deposits from such a period exist, they were overridden by later activity.

Between about 8,000 and 5,000 years B.P., a relatively warm, dry period (the Hypsithermal) occurred in the Pacific Northwest, causing a maximum recession of glaciers. This was followed by a resurgence in glacial activity in response to a cooler, wetter climate commonly referred to as the Neoglacial geologic-climate period (Porter and Denton 1967, p. 177). Neoglacial deposits are common in the 0lympics and North Cascades, and multiple advances have been recognized in both ranges (Table X). However, as ide from the work by Heusser (1957), no dates for Neoglacial deposits greater than a few centuries old have been documented in the olympics. The unpublished chronology devised by Long (1975a) for the northeast 0lympics relies on relative assessment of age based on vegetation cover, presence or absence of soil, and topographic relations; it does not give limiting ages for any of the deposits. Under Long's chronology, Akela rock glacier is considered to be of 
middle Neoglacial or "Constance" age (Long 1975a, p.45) (Table X). Most likely, the Akela rock glacier became active following the Hypsithermal interval, some 5,000 to 3,000 years B.P., and some parts may have remained active up to a few hundred years ago; stagnant subsurface ice could have persisted even longer. At the end of the Hypsithermal, the upper cirque area would have had as much as 8,000 years worth of debris accumulated since the last glaciation. With the coming of a more severe climate, this debris was able to move downslope as a rock glacier in conjunction with fresh debris eroded from the headwall area.

Rock glacier activity continued for at least 2,000 years, but movement may have been slow enough along the lateral edges to allow for accumulation of fine-grained material, vegetation establishment, and soil development. Downslope movement measurements on other tongue-shaped rock glaciers indicate that movement tends to be greatest along the central axis of the feature, while the lateral portions are much less active (Benedict et a1. 1985, p. 351). As rock glacier activity began to diminish at Akela, the lateral ridges were probably first to stabilize.

By several hundred years ago the rock glacier had probably stabilized sufficiently to allow lichens to become established on the rock surfaces. The age of the oldest Rhizocarpon thalli found on Akela rock glacier is estimated to range in age from 300 to just over 1,000 years. Pending the establishment of a growth-curve for lichens of the northeast 01 ympics, lichens can only be used as approximate measures of the age of substrate stability. 
Using tree core data at the Blue Glacier on Mount 0lympus, Heusser (1957, P. 144) found moraines that dated from at least 730 years B.P., but were possibly as old as 1,300 years B.P.; these may correlate with the end of the main period of rock glacier activity at Akela. If the Akela rock glacier is correlative with this glacial advance, it seems likely that the slower response of rock glaciers to climatic amelioration may have allowed the rock glacier to continue to be active beyond the time of glacial recession, thereby accounting discrepancies in ages between the two features.

Some of the small glaciers in the northeast 0lympics display fresh morainal deposits beyond their present termini which date back to the mid-19th century (Long 1975a, p. 31). Similar aged deposits have been described by Heusser (1957) at Mount 01ympus, by Miller (1969) at Dome Peak, and by Waitt et al. (1982) in the eastern Cascades. Crandell and Miller (1974, p. 50) reported that some moraines dated from the mid-1800's on Mount Rainier represent the furthest extent of Holocene glaciation for that glacier. Apparently, Akela rock glacier did not respond to the climatic conditions which produced these glacial advances. Since the headwall and talus above Akela rock glacier are not very active today, they may not have produced sufficient coarse blocky debris to sustain a rock glacier. It is possible that despite the presence of climatic conditions conducive to rock glacier activity, the lack of source material prevented reactivation of the rock glacier. Following stabilization of the rock glacier, geomorphic activity was probably limited to settling caused by melting of pockets of subsurface ice, slope creep, and occasional rockfalls and avalanching from above. 
CHAPTER VII

CHARACTER AND DISTRIBUTION OF ROCK GLACIERS IN THE NORTHEAST OLYMPICS

The general form, surface character and distribution of rock glaciers in the northeast 01ympic Mountains was assessed from a survey of aerial photographs covering the U.S.G.S. Tyler Peak $15^{\prime}$ quadrangle (Figure 24). This section of the 01ympics was selected for the survey because previous reports indicated that the majority of rock glaciers in the 01ympics are found with in this area (Long 1975a, pp. 39-41; Nebert 1984); a few rock glaciers outside the survey area have been reported by Nebert (1984), but aerial photographs for these sites were unavailable. One rock glacier just west of the survey area, at Maiden Peak, was included within the survey since it in 1983 and 1986.

Since the distinction between rock glaciers, pro talus ramparts and glacial moraines was not always obvious on the aerial photographs, only those landforms which clearly resembled rock glaciers in form and surface morphology were selected for comparison. Several pro talus ramparts in the area display slightly arcuate form and might liberally be interpreted as rock glaciers; they were not included in this survey because they lacked the distinctive surface morphology indicative of rock glaciers. The criteria used for distinguishing the rock glaciers included a tongue or lobate form, and the presence of transverse or longitudinal ridges and furrows or surface pits.

Eight rock glaciers were found in the survey area. Undoubtedly, 


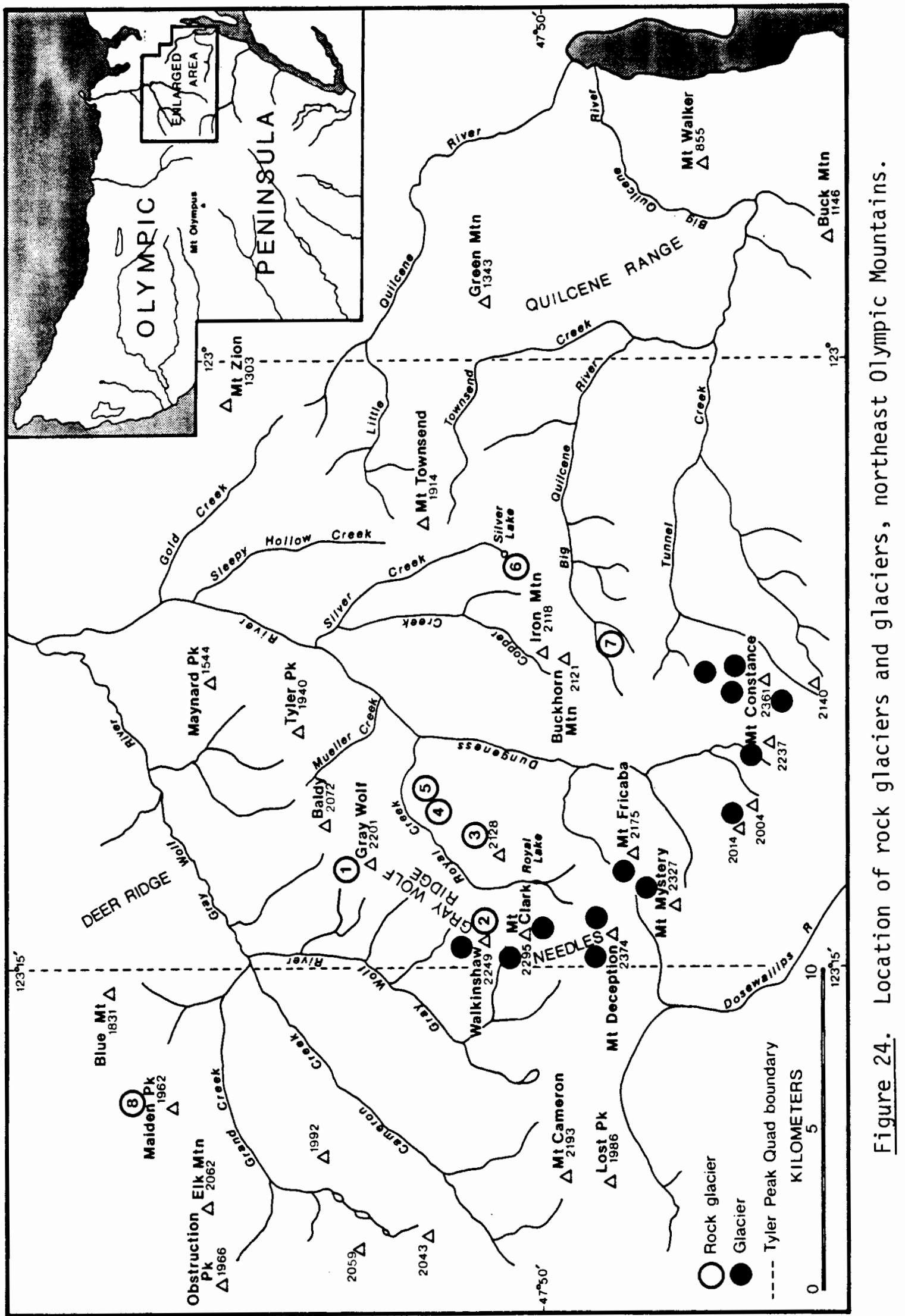


several others exist, but were not evident on the aerial photographs because of such factors as vegetation cover, erosion of original form, or inundation by modern talus. Despite the possibility that several rock glaciers may have been left unreported, the total number of rock glaciers in the $01 y m p i c$ Mountains is quite small in relation to more continental alpine areas such as the Rockies. This suggests that only a limited number of locations exhibited the necessary topoclimatic and geologic conditions conducive to rock glacier formation. In order to compare and contrast the nature and environment of rock glaciers in the survey area, data regarding elevation, aspect, form, size, surface morphology, and vegetation cover were gathered from aerial photographs, geologic and topographic maps, and field reconnaissance (Table XI).

\section{FORM AND SURFACE CHARACTER}

\section{Form and Activity}

Six of the rock glaciers are tongue-shaped and two are lobate (Table XI). There appears to be no relationship between form of the rock glacier and whether or not it heads in a cirque or along a valley wall; three of the tongue-shaped rock glaciers head in cirques while the other three originate along valley walls. Surface morphology tends to be complex, with most displaying some combination of ridge and furrow topography and pits. Maiden Peak rock glacier has a very large pit at its head and a distinct central furrow, suggesting that it may have been ice-cored (Vernon and Hughes 1966, p. 17); none of the other rock glaciers shows this combination of characteristics, although small pits are common in the areas between the rock glacier heads and the cliff 


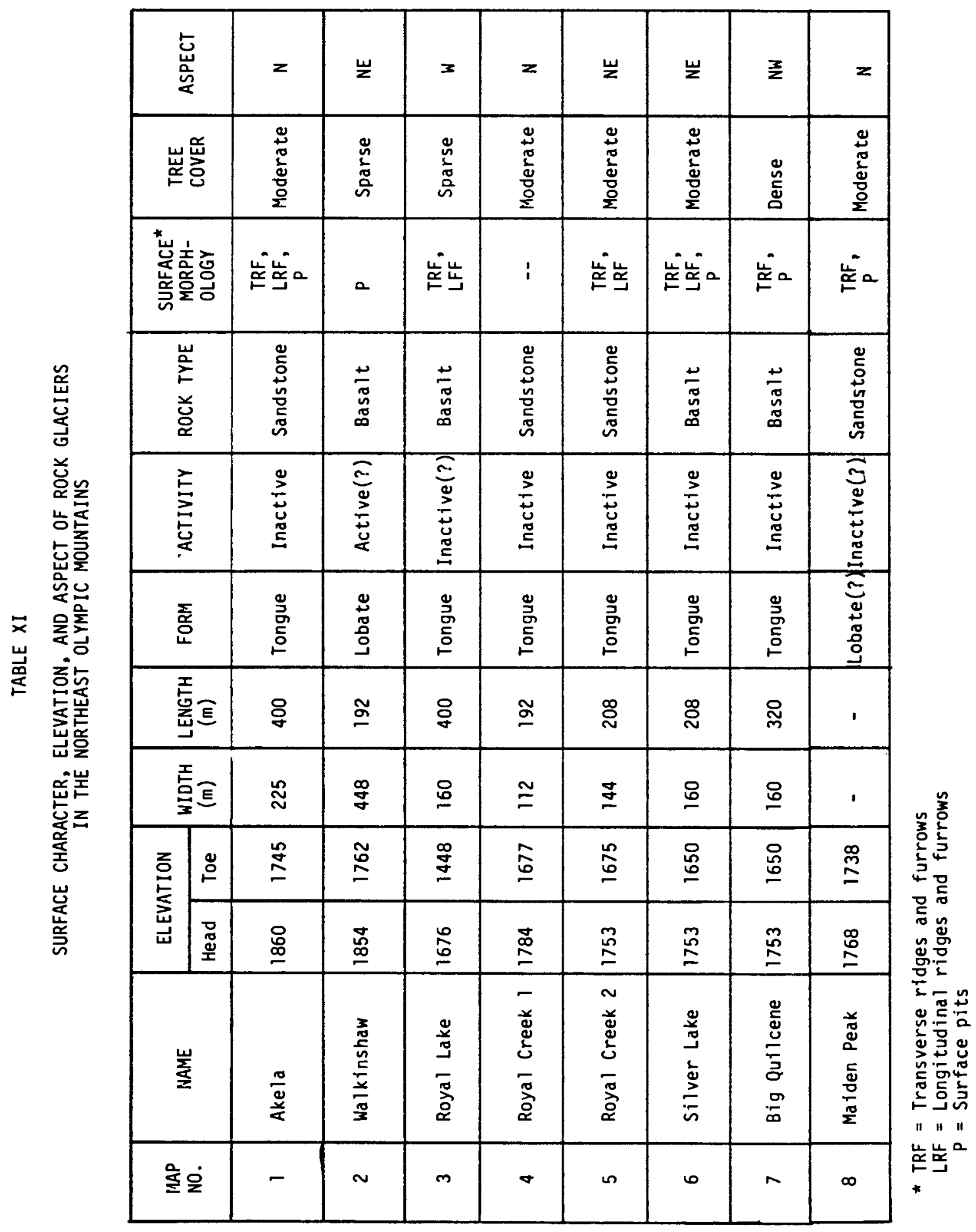


walls above them.

All but one of the rock glaciers are believed to be inactive because they have well-vegetated fronts that meet the top surface of the rock glacier at a rounded angle. One rock glacier, Walkinshaw, may still be active since it displays a sharp angle between the rock glacier front and its top surface (Figure 25). The Walkinshaw rock glacier front also has few boulders with surface oxidation or lichen cover, suggesting recent activity. Between the Walkinshaw rock glacier and the cliff wall above it, a section of clear ice was found with in the interstices of large boulders at the bottom of a pit. This discovery, made in early September of a dry year when almost all the late-lying snow in the surrounding highlands had melted, suggests that ice may be preserved in greater amounts deeper with in the rock mass.

The Walkinshaw rock glacier is the highest in elevation and has the most active talus supply of any of the other sites. Still, several small trees growing on the rock glacier front indicate that its movement is minimal at present. Most probably, the last major period of activity was associated with the mid-nineteenth century Neoglacial advance recognized at nearby glacier termini (Long 1974, p. 14). The Walkinshaw rock glacier has clearly been active more recently than any of the other rock glaciers in the area.

\section{Rock Type}

Information on the lithology of rock glacier source material was taken from the geologic map by Cady et al. (1972). Field inspection of five of the rock glaciers indicated that they are found only where there is a source of coarse, blocky debris. This characteristic, in keeping 


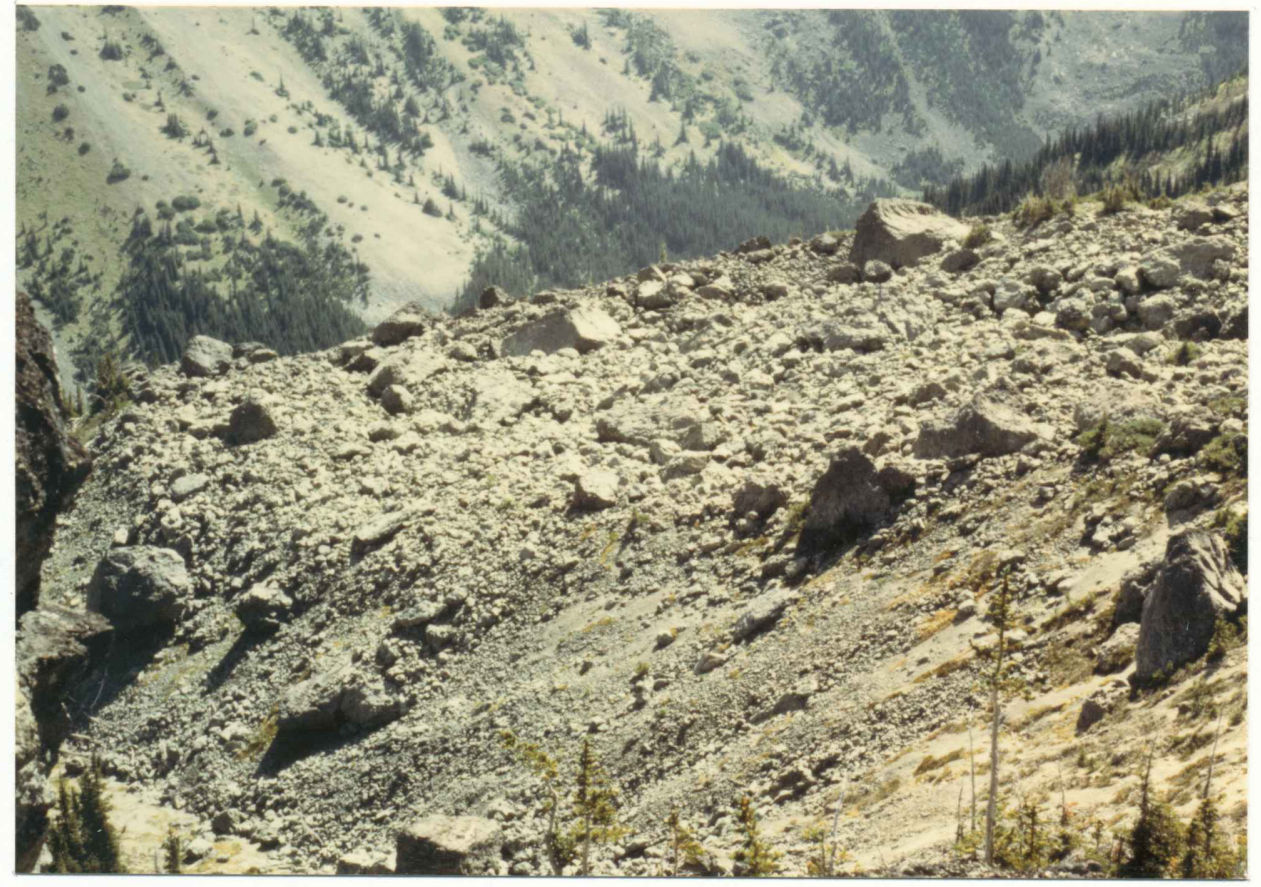

Figure 25. Sharp-angled front of Walkinshaw rock glacier, northeast $01 y m p i c$ Mountains. 
with the findings from other rock glacier studies (Wahrhaftig and Cox 1959, p. 414; Barsch 1977, p. 240; Luckman and Crockett 1978, p. 540 and others), is clearly illustrated at the Walkinshaw rock glacier (Figure 24), which lies below a vertical contact between very blocky basalt and finely jointed sandstone. The rock glacier forms almost entirely from the basalt, while the adjoining sandstone cliffwall has produced only steep talus.

Half of the rock glaciers in the northeast 0lympics are derived from a sedimentary suite of thickly bedded sandstone and more finely bedded siltstone and slaty mudstone similar to Akela rock glacier; the other half are composed of extremely coarse basaltic rubble. In comparison, there is a noticeable difference in the surface texture of the basaltic rock glaciers as opposed to those composed of sedimentary rocks. For example, numerous basalt boulders on the Royal Lake and Walkinshaw rock glaciers have diameters of over $15 \mathrm{~m}$, while the largest sandstone boulders observed at Akela or Maiden Peak were no greater than three to four meters in diameter.

The basaltic rock glaciers are noticeably lacking in fine surface sediments, while surface fines are relatively abundant at the sandstone rock glaciers. The absence of fine sediments, together with a lack of soil development on the basaltic rock glaciers is probably more indicative of the weathering rate of the parent material than it is of the age of the rock glaciers. The sandstones and associated sedimentary rocks are more easily comminuted than the harder basalts, and their interstices have been more readily filled in with fine debris. For example, despite the presence of trees older than 200 years (as 
determined by tree core samples), there are only scattered pockets of surficial fine material on the most densely vegetated ridges of the basaltic Silver Lake rock glacier (Figure 24). In contrast, the surface matrix under similar aged stands on Akela rock glacier is composed of ample amounts of fine sediments with obvious soil development. This disparity in weathering rates between sites eliminates the use of soil development as a means of comparing age characteristics of rock glacier deposits of differing lithologies.

It was also impossible to use corner angularity as a weathering index for comparative relative age dating between the basalt and sandstone boulders. The more slowly weathering basalt does not lose its angularity as quickly as the sandstone. Also, rounded pillow basalt cobbles are common in the rock glacier debris. Since the roundness of the pillow basalt boulders is not an indication of the relative age of the deposit, the use of corner angularity measurements with the basalts is not consistent.

\section{Vegetation Cover}

All of the rock glaciers except Walkinshaw and Royal Lake display moderate to dense vegetation cover (Table XI) and occur at or below the present treeline. There is a consistent tendency for trees to grow on ridges and lower lobe faces of the rock glaciers. Ridges are preferred locations for vegetation establishment for two reasons. First, the ridges are the first areas to become free of snow in the spring and summer, and therefore the trees have a longer growing season. Secondly, the lateral ridges tend to be the least active and therefore trees are more likely to become established on the more stable ground. Furrows 
and pits on the rock glaciers display the least vegetation because late-lying snow persists in these areas, shortening the growing season.

The sparseness of vegetation on the surface of Walkinshaw rock glacier is attributed to the continued supply of talus debris onto its surface and to the recency of its activity. The Royal Lake rock glacier is more difficult to interpret (Figure 24). The toe of this feature lies well below tree line and is surrounded by dense forest in its lower reaches. The forest appears to be encroaching onto the rock glacier, but much of the rock glacier surface remains unvegetated. The talus which feeds the rock glacier is still active, but far removed from lower lobe areas. Avalanching may be responsible for preventing tree establishment in places. There are numerous dead tree trunks and tree debris scattered within the rock glacier furrows, evidently transported downslope by avalanching. In addition, the coarseness of the basaltic debris probably inhibits seedling establishment.

\section{DISTRIBUTION}

\section{Location}

The overriding distributional control upon the presence of rock glaciers in the $01 y m p i c$ Mountains is the strong precipitation shadow created by the high central 0lympic Mountains. Rock glaciers are only found in the more continental northeastern section of the 0lympics, and are most prevalent in the lee of the high Needles Ridge and Mt. Constance Massif. The rapid decline in summit elevations north and east of these areas prevents rock glacier development in these directions. When the locations of the rock glaciers are plotted together with the 
locations of existing glaciers in the survey area, a noticeable trend in distribution can be seen (Figure 24). While the glaciers tend to cluster about the high basaltic peaks of the Needles Ridge and Mount Constance Massif in the southwestern portion of the survey area, rock glaciers are located towards the northeast, further into the $01 y m p i c$ precipitation shadow. This distribution is in keeping with the known tendency for rock glaciers to occupy drier, more continental locations than glaciers.

\section{Aspect and Elevation}

Rock glacier aspect (Table XI) varies between northeast and northwest, except for the Royal Lake rock glacier, which originates along a west-facing headwal1. The west-facing orientation at Royal Lake is peculiar because the head elevation for this rock glacier is almost $100 \mathrm{~m}$ lower than any of the others (Table XI); mean toe elevation for the rock glaciers is $1682 \mathrm{~m}$, but the toe of Royal Lake rock glacier lies at an elevation of $1448 \mathrm{~m}$. Because of this, the Royal Lake rock glacier is unusual compared to the other rock glaciers in the area. Although its form and surface character strongly favor interpretation as a rock glacier, its western exposure and low elevation suggest that its formation was less climatically induced than the others. Other than the Royal Lake rock glacier, the variability in rock glacier elevation and aspect may be attributed to differences in environment produced by such effects as topographic shading, snow cover, and debris supply. Elevational differences between the rock glaciers probably reflect differences in a combination of these local environmental controls more than regional effects. The total area of rock glacier distribution is 
too 1 imited to reflect regional elevational trends in response to gradients of precipitation or continentality.

A comparison between the elevation and aspect of rock glaciers and existing glaciers in the survey area shows that glaciers and large perennial snowfields also tend to favor northeast to northwest aspects (Figure 26a). Although data regarding snowl ine elevations for northeast Olympic glaciers are not available, the snowl ine for small cirque glaciers in midlatitude mountains is usually very close to the termini (Barsch 1971, p. 205). In comparison, the mean terminus elevation for northeast 01 ympic glaciers is higher than the mean rock glacier head elevation.

Neoglacial moraines have been identified downvalley from several of the existing glaciers (Long 1975a, p.45). These "Constance" aged glacial deposits display vegetation cover, topographic setting, and weathering characteristics similar to most of the inactive rock glaciers; although no quantitative comparative age data are available, they are assumed to be roughly correlative in age with the rock glaciers. Figure 26b compares toe elevations of rock glaciers to elevations of these morainal deposits. The figure indicates that even though rock glaciers in the northeast 01 ympics formed at lower elevations than glaciers, they did not extend downvalley as far as the Neoglacial deposits left by glaciers. Most studies which involve comparisons between glaciers and rock glaciers indicate that rock glaciers tend to originate at and extend to lower elevations than glaciers (Wahrhaftig and Cox 1959, p. 408; Madole 1972, p. 125; Luckman and Crockett 1978, p. 545). Rock glaciers form at lower elevations than 


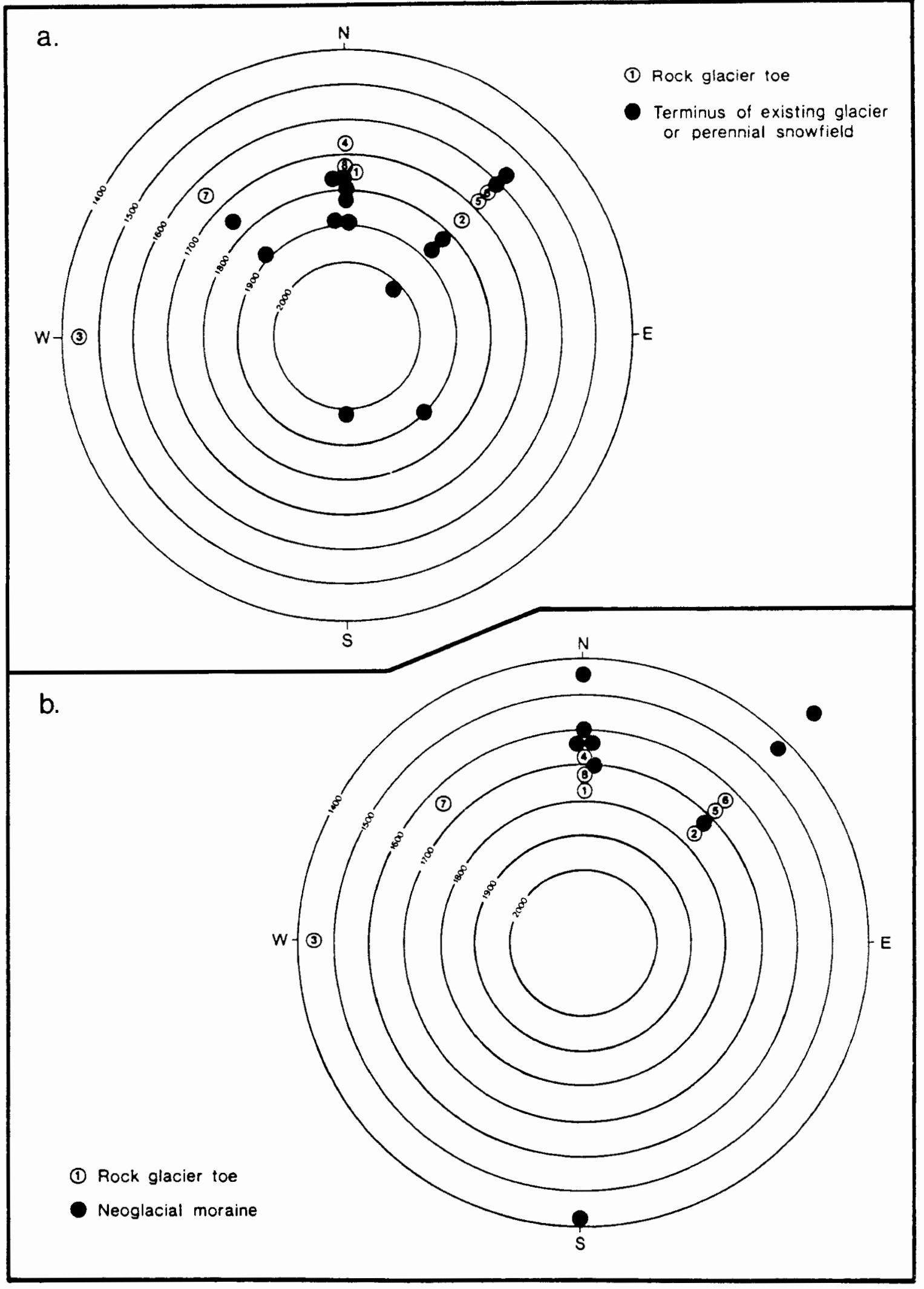

Figure 26. Aspect and elevation of rock glaciers versus past and present glaciers, northeast 01ympic Mountains. 
glaciers either as the debris-covered termini of glaciers or because environmental conditions are not snowy enough to sustain glaciers. In general, rock glaciers extend further downvalley than glaciers because the insulative effect of their debris mantle makes them less sensitive to environmental warming at lower elevations than the exposed clean ice surfaces of glaciers.

The rock glaciers in the northeast 0lympics formed in areas of marginal snow accumulation in comparison to areas where glaciers formed. This was because the rock glacier locations were further into the 0lympic precipitation shadow, and also because they formed at lower elevations than the glaciers. The Neoglacial snowl ine was lower than today and glacier accumulation zones were more expansive. Since snowl ine could not have been lower than rock glacier head elevations and it is likely that perennial snowfields or small glaciers existed directly above the rock glaciers, the mean rock glacier head elevation might be used to approximate the Neoglacial snowline. The snowfield/glaciers provided snow, ice, and meltwater for rock glacier development, but terminated at or very near the snowline. In contrast, the glaciers around the Needles and Mount Constance had much larger accumulation zones because of their higher elevation and greater receipt of precipitation; therefore, they were able to extend their termini well beyond the snowl ine.

There are two possible explanations for why rock glaciers did not flow as far downvalley as the glaciers. First, as mentioned, glaciers were responding to increased accumulation zones. The simple fact that they formed in snowier and colder topoclimatic locations allowed them to 
extend their ablation zones much further downvalley than the rock glaciers. A second possibility is that the rock glaciers discontinued moving downslope because they did not have a sufficient debris supply. That is, once the initial debris that had been accumulating below the headwall since the last major glaciation was transported away from the headwa 11, there was an insufficient debris supply from the headwall for continued rock glacier formation. In this situation, the upper portion of the rock glacier would slowly thin as it moved away from the headwal1. At the same time, the lower portion would thicken due to compressive flow, and the overall rock glacier gradient would decrease (cf. Benedict et al. 1986, p. 351). Without the overlying weight of a continued debris supply, rock glacier motion would be severely retarded, especially where the rock glacier had flowed onto terrain of lower gradient. This may be the case for the sandstone-derived rock glaciers at Akela, and Royal Creek One and Two, where the talus no longer contributes appreciable debris onto the upper rock glacier surface (Figure 24).

The situation for the basaltic rock glaciers is complicated by the presence of two rock glaciers that obviously do not fit this pattern -Royal Lake and Walkinshaw (Figure 24). As previously mentioned, the Royal Lake rock glacier occurs at an elevation well below any of the glacial or rock glacial deposits despite its unfavored aspect. The low elevation of this rock glacier must result from a combination of very abundant debris supply and instability of the very steep talus above it. Only a very well insulated ice core/matrix could have allowed a rock glacier to develop in this location. Although it is possible that the 
high cliffs and steep taius above Royal Lake may have been able to provide an adequate debris mantle for this, an alternative explanation is that the rock glacier was formed by a landslide or debris avalanche during the winter. This would have allowed rapid downslope movement of a large quantity of debris and burial of snow and ice which may have persisted and allowed for subsequent creep or flow of the rock glacier in its lower reaches.

The Walkinshaw rock glacier, which appears to be the most recently active of the rock glaciers, continues to be inundated by debris from the talus above it. Any movement away from the headwall has been matched by continued resupply of coarse debris. The elevation of the rock glacier is close to the modern glacial snowl ine and the toe extends downslope below the elevation for the mean existing glacier termini. Thus, with an ample supply of debris, rock glaciers in the northeast 0lympics may be able to extend further downslope than glacier termini.

\section{Permafrost Implications}

The distribution of alpine permafrost, like rock glaciers, is controlled by such factors as topography, aspect and snow distribution. Discontinuous alpine permafrost is reported to occur where mean annual air temperatures of -1 to $-2^{\circ} \mathrm{C}$ exist (Ives 1974, p. 188; Washburn 1980, p. 230); in the Swiss Alps, Barsch (1978, p. 350) reported that the lower limit of active rock glaciers occurs at about the $-2^{0}$ mean annual isotherm. Except in the case of aclimatic forms (e.g., ice-cored rock glaciers which are not in balance with environmental conditions for their elevation), rock glaciers are indicative of discontinuous alpine permafrost (Washburn 1980, p. 231). 
The presence of inactive rock glaciers in the northeast 01 ympic Mountains strongly suggests the former existence of permafrost. Excluding the Royal Lake rock glacier, the toe elevation of these features ranges between about $1650 \mathrm{~m}$ and $1750 \mathrm{~m}$, with a mean of $1703 \mathrm{~m}$ (Table XI). Thus, it is thought that the lower range of discontinuous permafrost in the northeast 01ympics during the Neoglacial maximum was at approximately $1700 \mathrm{~m}$.

The existence of permafrost above the $1700 \mathrm{~m}$ level helps to explain the presence of turf-banked terraces (Hansen 1976; Hansen-Bristow and Price 1985) and various forms of patterned ground on the hillslopes and divides in the northeast 0lympics. Although permafrost is not an essential component in the formation of any of these features, the fact that all of them have developed in close proximity strengthens the case for the former presence of permafrost. The toe elevation of $1448 \mathrm{~m}$ for the Royal Lake rock glacier suggests that patches of sporadic alpine permafrost may have ocurred considerably lower than the $1700 \mathrm{~m}$ level. 


\section{CHAPTER VIII}

\section{SUMMARY AND CONCLUSIONS}

Two lines of inquiry were pursued in this thesis. First, the geomorphic character and age of Akela rock glacier was investigated in order to better understand the mechanisms of rock glacier formation and to identify the main period of rock glacier activity. This was accomplished through analys is of the rock glacier surface morphology and the use of relative and absolute dating techniques. The second purpose was to analyze the distribution of rock glaciers in the northeast olympics in terms of topoclimatic and geologic controls, and to compare their distribution with past and present true glaciers in order to better understand the environment in which they formed.

Akela rock glacier is the largest and best developed rock glacier in the $01 y$ mpic Mountains. Its form and surface character clearly distinguish it from such features as glacial moraines or catastrophic rockfall deposits. Several lines of evidence indicate the rock glacier is no longer active, including: the presence of trees and lichens on the rock glacier toe and upper lobe face; a rounded angle of intersection between the rock glacier front and its upper surface; the prevalence of fine-grained surface material; and a lack of abundant debris supply from the talus and headwall above the rock glacier.

Stratigraphic evidence indicates that the lower Akela cirque basin has not been glaciated for more than 10,000 years. Accumulation of 
talus since the last Pleistocene glacial event, together with ongoing rockfall and avalanche activity in the upper cirque area provided an ample supply of debris for rock glacier formation. The rock glacier appears to have formed some 5,000 to 3,000 years ago, with some portions possibly remaining active up to about 300 years ago.

Data derived from measurements of boulder weathering, lichen coverage, and soil development show that the surface of Akela rock glacier is variably-aged. Boulders at the head of the rock glacier are more recently deposited and have not been influenced by rock glacier flow as indicated by their angularity, low percentage lichen cover, and lack of preferred long axis orientation. In contrast, boulders at the rock glacier toe are more weathered with a high percentage lichen cover. Boulders at the rock glacier toe and upper lobe face display a preferred orientation, which is probably due to past rock glacier movement. Soil development and establishment of vegetation on lateral ridgetops indicate that these areas were first to stabilize, probably more than 1,000 years ago.

Contemporary talus activity above Akela rock glacier is minimal. It is hypothesized that in addition to a warming climate, the lack of a continued supply of coarse blocky debris from the headwall and talus led to the stagnation and inactivity of the rock glacier.

The presence of several other rock glaciers in the $01 y$ mpic Mountains indicates that the environmental conditions for rock glacier formation were not unique to the Akela cirque basin. The distribution of rock glaciers in the $01 y m p i c$ Mountains is influenced by several factors. Most importantly, they only occur in the more continental 
northeastern section of the 0lympics. With in this area, rock glaciers are preferentially located to the lee of the high Needles Ridge and Mt. Constance Massif, where precipitation is most limited. Rock glaciers tend to display northwest to northeast aspects, and are restricted to areas where there is an abundant source of coarse blocky debris. Most of the rock glaciers appear to be of similar age and are no longer active. A notable exception, the Walkinshaw rock glacier, has clearly been more recently active than any of the others.

Rock glaciers appear to have formed at lower elevations than glaciers of similar age, but often they did not flow as far downvalley as the glaciers. This characteristic is attributed to the more expansive accumulation zones of the Neoglacial glaciers, as well as the tendency for rock glaciers to be unable to move downslope without a continued debris supply. The mean rock glacier toe elevation of about $1,700 \mathrm{~m}$ suggests an approximate lower limit for discontinuous permafrost during the Neoglacial maximum.

Despite the presence of rock glaciers and other cold climate geomorphic features such as turf-banked terraces and patterned ground, the topic of periglacial phenomena and processes has received little attention in the 0lympic Mountains and other mountains of the Pacific Northwest (Hansen-Bristow and Price 1985, p. 269). Although periglacial features are not as abundant in the 0lympics or Cascades as more continental alpine areas such as the Rockies, these features are perhaps more widespread than given credit for in the literature. Further studies regarding the environment and distribution of rock glaciers and other periglacial phenomena in the Pacific Northwest would be a valuable 
addition to our understanding of past and present geomorphic processes in the region, as well as to paleoclimatic reconstruction. 


\section{REFERENCES CITED}

American Society for Testing and Materials, 1977, 1977 Annual Book of A.S.T.M. Standards, Part 19, pp. 70-80, Philidelphia, PA: American Society for Testing and Materials.

Balch, E.S., 1897, "Ice Caves and the Causes of Subterranean Ice," Journal of the Franklin Institute, Vol. 143, No. 3, pp. 161-78.

Barnosky, C.W., 1984, "Late Pleistocene and Early Holocene Environmental History of Southwestern Washington State, U.S.A.," Canadian Journal of Earth Science, Vol. 21, pp. 619-29.

Barsch, D., 1971, "Rock Glaciers and Ice-Cored Moraines," Geografiska Annaler, Vol. 53A, Nos. 3-4 pp. 203-206.

1977, "Nature and Importance of Mass-Wasting by Rock Glaciers in Alpine Permafrost Environments," Earth Surface Processes, Vol. 2, pp. $231-45$.

1978, "Rock Glaciers as Indicators for Discontinuous Alpine Permafrost. An Example From the Swiss Alps," in Proceedings of the Third International Conference on Permafrost, July 10-13, 1978, Edmonton, Alberta, Canada. National Research Council of Canada, Ottawa, Vol. 1, pp. 349-52.

Barsch, D. and L. King, 1975, "An Attempt to Date Fossil Rock Glaciers in Grison, Swiss Alps (A Preliminary Note)," Quaestiones Geographicae, Vol. 2, pp. 5-14.

Barsch, D. and R. Updike, 1971, "Late Pleistocene Periglacial Geomorphology (Rock Glaciers and Block Fields) at Kendrick Peak, Northern Arizona," Arizona Geological Society Digest, Vol. 9, pp. 225-43.

Beget, J.E., 1984, "Tephrachronology of Late Wiscons in Deglaciation and Holocene Glacier Fluctuations Near Glacier Peak, North Cascades, Washington," Quaternary Research, Vol. 21, No. 3, pp. 304-16.

Benedict, J.B., 1968, "Recent Glacial History of an Alpine Area in the Colorado Front Range, U.S.A., II. Dating the Glacial Deposits," Journal of Glaciology, Vol. 7, pp. 77-87.

-1981 , The Fourth of July Valley: Glacial Geology and Archeology of the Timberline Ecotone, Research Report 2, Center for Mountain Archeology, Ward, Co., 139 pp. 
Benedict, J.B., Benedict, R.J. and D. Sanville, 1985, "Arapaho Rock Glacier, Front Range, Colorado, U.S.A.: A 25-Year Resurvey," Arctic and Alpine Research, Vol. 18, No. 3, pp. 349-52.

Birkeland, P.W., 1973, "Use of Relative Age Dating Methods in a Stratigraphic Study of Rock Glacier Deposits, Mt. Sopris, Co.," Arctic and Alpine Research, Vol. 5, No. 4, pp. 401-16.

1982, "Subdivision of Holocene Glacial Deposits, Ben Ohau Range, New Zealand using Relative-Dating Techniques," Geological Society of America Bullet in, Vol. 93, pp. 433-49.

Blagbrough, J.W. and S.W. Farkas, 1968, "Rock Glaciers in the San Mateo Mts., South-Central New Mexico," American Journal of Science, Vol. 266, pp. 812-23.

Brown, W.H., 1925, "A Probable Fossil Glacier," Journal of Geology, Vol. 33 , No. 4, pp. 464-66.

Burke, R.M. and P.W. Birkeland, 1983, "Holocene Glaciation in the Mountain Ranges of the Western United States," in H.E. Wright (ed.), Late Quaternary Environments of the United States.

Butler, D.R., 1984, "Reinterpretation of a Late Pleistocene Moraine in the Lemhi Mountains of Idaho, U.S.A.," Zeitschrift fur Geomorphologie, Vol. 28, No. 3, pp. 333-46.

Cady, W.M., Tabor, R.W., et al., 1972, "Geology of the Tyler Peak Quadrangle, Washington," United States Geological Survey Quadrangle Map, GQ-970.

Caine, N., 1967, "The Texture of Talus," Journal of Sedimentary Petrology, Vol. 42, pp. 33-48.

-1972, "The Fabric of Periglacial Blockfield Material on Mt. Barrow, Tasmania," Journal of Sedimentary Petrology, Vo1. 42, pp. 33-48.

Capps, S.P., 1910, "Rock Glaciers in Alaska," Journal of Geology, Vol. 18, pp. 359-75.

Carver, G.A., 1972, "Glacial Geology of the Mountain Lakes Wilderness and Adjacent Parts of the Cascade Range, Oregon," unpublished Ph.D. dissertation, University of Washington.

Chaix, A., 1923, "Les Coulees de Blocs du Parc National Suisse d'Engadine (Note Preliminaire)," Le Globe, Vol. 62, pp. 1-34.

Corte, A.E., 1976, "Rock Glaciers," Biuletyn Peryglacyjolny, Vol. 26, pp. 175-98. 
Crandell, D.R., 1965, "The Glacial History of Western Washington and Oregon," pp. 341-53, in H. Wright and D. Frey (eds.), The Quaternary of the United States, Princeton: Princeton University Press, $922 \mathrm{pp}$.

Crandell, D.R. and R.D. Miller, 1974, "Quaternary Stratigraphy and Extent of Glaciation in the Mount Rainier Region, Washington," United States Geoloogical Survey Professional Paper, No. 847, 59pp.

Cross, C.W. and E. Howe, 1905, "Description of the Silverton Quadrangle," United States Geological Survey At las of the United States, Silverton Folio, No. 120, 34 pp.

Davis, J.C., 1986, Statistics and Data Analys is in Geology, Second Edition, New York: John Wiley and Sons, 646 pp.

Easterbrook, D.J. and D.A. Rahm, 1970, Landforms of Washington: The Geologic Environment, Bellingham, Washington: Union Printing, 156 $\mathrm{pp}$.

Ellis, J. and P. Calkin, 1979, "Nature and Distribution of Glaciers, Neoglacial Moraines, and Rock Glaciers, East-Central Brooks Range, Alaska," Arctic and Alpine Research, Vol. 11, pp. 403-20.

Fonda, R.W. and L.C. Bliss, 1969, "Forest Vegetation of the Montane and Subalpine Zones, Olympic Mountains, Washington," Ecological Monographs, Vol. 39, No. 3, pp. 271-301.

Foster, H.L. and G.W. Holmes, 1965, "A Large Transitional Rock Glacier in the Johnson River Area, Alaska Range," United States Geological Survey Professional Paper, No. 525-B, pp. B112-B116.

Franklin, J.F. and C.T. Dyrness, 1973, "Natural Vegetation of Oregon and Washington," United States Department of Agriculture, Forest Service General Technical Report, PNW-8, Portland, Oregon.

Gardner, J.S., 1973, "The Nature of Talus Shift on Alpine Talus Slopes: An Example From the Canadian Rocky Mountains," pp. 95-106, in B.D. Fahey and R.D. Thompson (eds.), Research in Polar and Alpine Geomorphology, Third Guelph Symposium on Geomorphology.

Giardino, J.R., 1983, "Movement of Ice-Cemented Rock Glaciers by Hydrostatic Pressure: An Example from Mount Mestas, Colorado, U.S.A.," Zeitschrift fur Geomorphologie, Vol. 27, pp. 297-310.

Giardino, J.R., Shroder, J.F. and M.P. Lawson, 1984, "Tree-Ring Analys is of a Rock Glacier Complex on Mount Mestas, Colorado, U.S.A.," Arctic and Alpine Research, Vol. 16, No. 3, pp. 299-309. 
Giardino, J.R. and J.D. Vitek, 1985, "A Statistical Interpretation of the Fabric of a Rock Glacier," Arctic and Alpine Research, Vol. 17, No. 2, pp. 165-77.

Haeberli, W., King, L. and A. Flotron, 1979, "Surface Movement and Lichen-Cover Studies at the Active Rock Glacier near the Grubengletscher, Wallis, Swiss Alps," Arctic and Alpine Research, Vol. 11, pp. 421-41.

Hansen, K.J., 1976, "The Nature and Distribution of Turf-Banked Terraces in the 0lympic Mountains, Washington," unpublished Master's thesis, Department of Geography, Portland State University, $81 \mathrm{pp}$.

Hansen-Bristow, K.J. and L.W. Price, 1985, "Turf-Banked Terraces in the 01 ympic Mountains, Washington," Arctic and Alpine Research, Vol. 17, No. 3, pp. 261-70.

Hansen-Bristow K.J. and J.D. Ives, in progress, "Age, Frequency, and Distribution of Seedlings Above Timberline," Department of Geography, Montana State University.

Hassinger, J.M. and P.A. Mayewski, 1983, "Morphology and Dynamics of Ten Rock Glaciers in Southern Victoria Land, Antarctica," Arctic and Alpine Research, Vol. 15, No. 3, pp. 351-68.

Heusser, C.J., 1957, "Variations of the Blue, Hoh, and White Glaciers during Recent Centuries," Arctic, Vol. 10, No. 3, pp. 139-50.

Hopkins, K., 1966, "Glaciation of Ingalls Creek Valley, East-Central Cascade Range, Washington," unpublished Master's thes is, University of Washington.

Howe, E., 1909, "Landslides in the San Juan Mountains, Colorado," United States Geological Survey Professional Paper, No. 67, 58 pp.

Hubley, R.C., 1956, "Glaciers in the Washington Cascade and 0lympic Mountains: Their Present Activity and its Relation to Local Cl imatic Trends," Journal of Glaciology, Vol. 2, pp. 669-74.

Ives, J.D., 1974, "Permafrost," pp. 159-94 in J.D. Ives and R.G. Barry (eds.), Arctic and Alpine Environments, London: Methuen.

Johnson, J.P., 1973, "Some Problems in the Study of Rock Glaciers," Zeitschrift fur Geomorphologie, Vol. 8, pp. 11-30.

Johnson, P.G., 1974, "Mass Movement of Ablation Complexes and The ir Relationship to Rock Glaciers," Geografiska Annaler, Vol. 56A, Nos. 1-2, 93-101.

-1983, "Rock Glaciers, a Case for a Change in Nomenclature," Geografiska Annaler, Vol. 65A, Nos. 1-2, pp. 27-34. 
Johnson, R.B., 1967, "Rock Streams on Mount Mestas, Sangre de Cristo Mountains, Southern Colorado," United States Geological Survey Professional Paper, No. 5750, pp. 0217-0220.

Kesseli, J.E., 1941, "Rock Streams in the Sierra Nevada," Geographical Review, Vol. 31, p. 203-27.

Kiver, E.P., 1974, "Holocene Glaciation in the Wallowa Mountains, Oregon," pp. 169-95, in W.C. Mahaney (ed.), Quaternary Environments, Toronto: York University Press, $318 \mathrm{pp}$.

Kuramoto, R.T. and L.C. Bliss, 1970, "Ecology of Subalpine Meadows in the 01 ympic Mountains, Washington," Ecological Monographs, Vol. 40 , No. 3, pp. 317-47.

Libby, W.G., 1968, "Rock Glaciers in the North Cascade Range, Washington (Abstract)," Geological Society of America Special Paper, No. 101, pp. 318-19.

Lliboutry, L., 1953, "Internal Moraines and Rock Glaciers," Journal of Glaciology, Vol. 2, p. 296.

Locke, W.W., Andrews, J.T. and P.J. Webber, 1979, "A Manual for

Lichenometry," British Geomorphological Research Group Technical

Bulletin, No. $26,47 \mathrm{pp}$.

Long, W.A., 1974, "Glaciation of the Needles," Summit, Vol. 20, No. 4, pp. $10-17$.

--1975a, "Neoglaciation in the Northeastern Olympic Mountains, Washington," unpublished manuscript, United States Forest Service, 01 ympia, Washington.

-1975b, "Glacial Geology of the Northern $01 y m p i c$ Peninsula," unpublished manuscript, United States Forest Service, Olympia, Washington.

$-1975 c$, "Salmon Springs and Vashon Continental Ice in the $01 y m p i c$ Mountains and the Relation of Vashon Continental to Fraser olympic Ice," unpublished manuscript, United States Forest Service, 01 ympia, Washington.

Luckman, B.H. and K.J. Crockett, 1978, "Distribution and Characteristics of Rock Glaciers in the Southern Part of Jasper National Park, Alberta," Canadian Journal of Earth Science, Vol. 15, No. 4, pp. 540-50.

Lundqvist, J., 1949, "The Orientation of Block Material in Certain Species of Flow Earth," Geografiska Annaler, Vo 1. 31, pp. 335-47.

Madole, R.F., 1972, "Neoglacial Facies in the Colorado Front Range," Arctic and Alpine Research, Vol. 4, pp. 119-30. 
Mahaney, W.C., 1973, "Neoglacial Chronology in the Fourth of July Cirque, Central Colorado Front Range," Geological Society of America Bulletin, Vol. 84, pp. 161-70.

-.-1980, "Late Quaternary Rock Glaciers, Mount Kenya, Africa," Journal of Glaciology, Vol. 25, No. 93, pp. 492-97.

McDowe 11, P., 1985, "Calculation of Particle Size Distribution from Hydrometer and Sieve Data," in unpublished Soils Laboratory Manua 1, Department of Geography, University of Oregon.

Mckee, B., 1972, Cascadia--The Geologic Evolution of the Pacific Northwest, New York: McGraw-HilT Book Co., 394 pp.

McSaveney, E., 1971, "The Surficial Fabric of Rockfall Talus," in M. Mor isawa (ed.), Quantitative Geomorphology: Some Aspects and Applications, Second Annual Geomorphology Symposium, Publicat ions in Geomorphoigy.

Miller, C.D., 1969, "Chronology of Neoglacial Moraines in the Dome Peak Area, North Cascade Range, Washington," Arctic and Alpine Research, Vol. 1, pp. 49-66.

Morris, S.E., 1981, "Topoclimatic Factors and the Development of Rock Glacier Facies, Sangre de Cristo Mountains, Southern Colorado," Arctic and Alpine Research, Vol. 13, No. 3, pp. 329-38.

Muller, S.W., 1947, Permafrost or Permanently Frozen Ground and Related Engineering Probtems, Ann Arbor, Mich.: Edwards Bros., $231 \mathrm{pp}$.

National Oceanic and Atmospheric Administration, (NOAA), 1985, "Climate of Washington," Climates of the States, Third Edition, Vol. 2, pp. 1169-207, Detroit, Michigan: Gales Research Company.

Nebert, D., 1984, "Environment and Distribution of Rock Glaciers in the 01 ympic Mountains, Washington U.S.A.," unpublished paper, Department of Geography, Portland State University.

Outcalt, S.I., and J.B. Benedict, 1965, "Photo-Interpretation of Two Types of Rock Glaciers in the Colorado Front Range, U.S.A.," Journal of Glaciology, Vol. 5, pp. 849-56.

Petersen, K.L., Mehringer, P.J. et al., 1983, "Late-Glacial Vegetation and Climate at the Manis Mastodon Site, Olympic Peninsula, Washington," Quaternary Research, Vol. 20, No. 2, pp. 215-31.

Porter, S.C., 1964, "Composite Pleistocene Snow Line of the 01 ympic Mountains and Cascade Range, Washington," Geological Society of America Bulletin, Vol. 75, pp. 447-82. 
--1981a, "Lichenometric Studies in the Cascade Range of

Washington: Establishment of Rhizocarpon geographicum growth

curves at Mount Rainier," Arctic and Alpine Research, Vol. 13, No.

1, pp. 11-23.

-1981b, "Use of Tephrachronology in the Quaternary Geology of the United States," pp. 135-60 in S. Self and R.S.J. Sparks (eds.), Tephra Studies, D. Reidel Publishing Co.

Porter, S.C. and G.H. Denton, 1967, "Chronology of Neoglaciation in the North American Cordillera," American Journal of Science, Vo1. 265, pp. $177-210$.

Porter, S.C. and G. Orombe11i, 1980, "Catastrophic Rockfall of September 12,1717 on the Italian Flank of the Mont Blanc Mass if," Zeitschrift fur Geomorphologie, Vol. 24, p. 200-218.

Potter, N., 1972, "Ice-Cored Rock Glacier, Galena Creek, Northern Absaroka Mountains, Wyoming," Geological Society of America Bulletin, Vol. 83, pp. 3025-58.

Rapp, A., 1960, "Recent Development of Mountain Slopes in Karkevagge and Surroundings, Northern Scandinavia," Geografiska Annaler, Vol. 42, pp. $71-200$.

Scott, W.E., 1977, "Quaternary Glaciation and Volcanism, Metolius River Area, Oregon," Geological Society of America Bullet in, Vol. 88, pp. 113-24.

Smith, H.T.U., 1973, "Photogeologic Study of Periglacial Talus Glaciers in Northwestern Canada," Geografiska Annaler, Vol. 55A, pp. 69-84.

Spencer, A.C., 1900, "A Peculiar Form of Talus," Science, Vol. 11, p. 188.

Sugden, D.E. and B.S. John, 1976, Glaciers and Landscape, London: Edward Árnold, $376 \mathrm{pp}$.

Tabor, R.W., 1975, Guide to the Geology of Olympic National Park, Seattie: University of Washington Press, $114 \mathrm{pp}$.

Tabor, R.W. and W.M. Cady, 1978a, "The Structure of the Olympic Mountains, Washington--Analys is of a Subduction Zone," United States Geological Survey Professional Paper, No. $1033, \overline{25} \mathrm{pp}$.

-...-1978b: "Geologic Map of the Olympic Peninsula, Washington," United States Geological Survey Miscellaneous Investigation Series Map, I-994. 
Thompson, W.F., 1962, "Preliminary Note on the Nature and Distribution of Rock Glaciers and Other Effects of the Climate on the Ground," International Association of Scientific Hydrology, Commission on Snow and Ice, Sympos ium of obergurgle, Publication 58, pp. 212-19.

Tyre11, J.B., 1910, "Rock Glaciers or Chrystocrenes," Journal of Geology, Vol. 28, pp. 549-53

United States Department of Agriculture, 1975, Soil Taxonomy: A Bas ic System of Soil Classification for Making and Interpreting Soil Surveys, Agricultural Handbook No. 436, Washington D.C., United States Government Printing Office.

Vernon, P. and 0.L. Hughes, 1966, "Surficial Geology, Dawson, Larson Creek, and Nash Creek Map-Areas, Yukon Territory," Canadian Geological Survey Bulletin, No. 136, 25 pp.

Wahrhaftig, C. and A. Cox, 1959, "Rock Glaciers in the Alaska Range," Geological Society of America Bullet in, Vol. 70, pp. 383-436.

Waitt, R.B., Yount, J.C. and P.T. Davis, 1982, "Regional Significance of an Early Holocene Moraine in Enchantment Lakes Basin, North

Cascade Range, Washington," Quaternary Research, Vol. 17, pp. 191-210.

Washburn, A.L., 1980, Geocryology: a Survey of Periglacial Processes and Environments, New York: John Wiley and Sons, $406 \mathrm{pp}$.

Weaver, C.E., 1937, "Tertiary Stratigraphy of Western Washingtion and Northeastern Oregon," Washingtion University Publications in Geology, No. 4, 266 pp.

Welter, S.P., 1983, "Talus: Form and Process in Three Pacific Northwest Mounta in Areas," unpublished report, Mountain Geography Summer Field Camp, Portland State University.

Whalley, W.B., 1974, "Rock Glaciers and Their Formation," University of Reading Geography Paper, Vol. 24, 60 pp.

White, S.E., 1971, "Rock Glacier Studies in the Colorado Front Range, 1961-68," Arctic and Alpine Research, Vol. 3, pp. 43-64.

-.--1976, "Rock Glaciers and Block Fields, Review and New Data," Quaternary Research, Vo 1. 6, pp. 77-97.

-1981, "Alpine Mass Movement Forms (Non-Catastrophic):

Classification, Description, and Significance," Arctic and Alpine Research, Vol. 13, pp. 127-37.

Yarnal, B.M., 1982, "Surface Sediment Analys is of a Rock Glacier," Journal of the International Association for Mathematical Geology, Vol. 14, No. 4, pp. 371-86. 


\section{APPENDIX}

\section{SOIL PARTICLE-SIZE ANALYSIS}

Particle-size analys is was conducted, with modification, according to the methodolgy outlined in American Society for Testing and Materials (1977). Each soil sample was oven-dried and then dry-sieved to remove all gravels, particles, and debris greater than $1.0 \mathrm{~mm}$ in diameter. Subsamples estimated to yield approximately 30 to 50 grams of silt and clay were then weighed out for hydrometer analys is.

Each subsample was soaked overnight in a dispersant solution of distilled water and Na-hexametaphosphate and then vigorously shaken for at least one hour on an electronic shaking machine. The subsamples were then placed in sedimentation cylinders filled with distilled water to the 1,000 $\mathrm{ml}$ level. Each cylinder was hand-shaken for 60 seconds then placed on a level countertop for timed hydrometer readings. Hydrometer readings were taken at 15 minutes, two hours, four hours, eight hours, and 12 hours. Each cylinder was then hand-shaken for an additional 60 seconds and hydrometer readings were taken at 40 seconds and at two minutes.

Readings were recorded on a data sheet from which calculations of percent weight in suspension and maximum particle diameter were made (Tables XII - XVIII). Percent weight in suspension (P) was calculated as $P=R_{c} / W \times 100$, where 


$$
\begin{aligned}
R_{C}= & \text { temperature corrected hydrometer reading } \\
= & R-R_{x} \\
R= & \text { actual hydrometer reading } \\
R_{x}= & \text { correction factor for hyrometer } 152 \mathrm{H}, \\
& \text { using dispersant of Na-hexametaphosphate } \\
& \text { at } 5.5 \mathrm{~g} / 1 \text { (MCDowe } 11 \text { 1985, p.3). }
\end{aligned}
$$

Maximum particle diameter (D) for each hydrometer reading was calculated as $D=K \times(L / T)^{0.5}$, where

$$
\begin{aligned}
K= & \text { a constant dependent on the temperature } \\
& \text { and specific gravity of the soil particles } \\
& \text { (American Society for Testing and } \\
& \text { Materials 1977, Table 3, p.77) } \\
\mathrm{L}= & \text { effective depth of the hydrometer } \\
& \text { (American Society for Testing and } \\
& \text { Materials 1977, Table 2, p.76) } \\
\mathrm{T}= & \text { time interval from beginning of } \\
& \text { sedimentation to the taking of the } \\
& \text { reading, in minutes. }
\end{aligned}
$$

A cumulative particle size distribution was then plotted on semi-logarithmic graph paper with particle size on the logarithmic scale and percent weight in suspension on the arithmetic scale. Percentage sand (coarser than $0.05 \mathrm{~mm})$, percentage silt $(0.05-0.002 \mathrm{~mm})$, and percentage clay (finer than $0.002 \mathrm{~mm}$ ) were determined from these plots. 


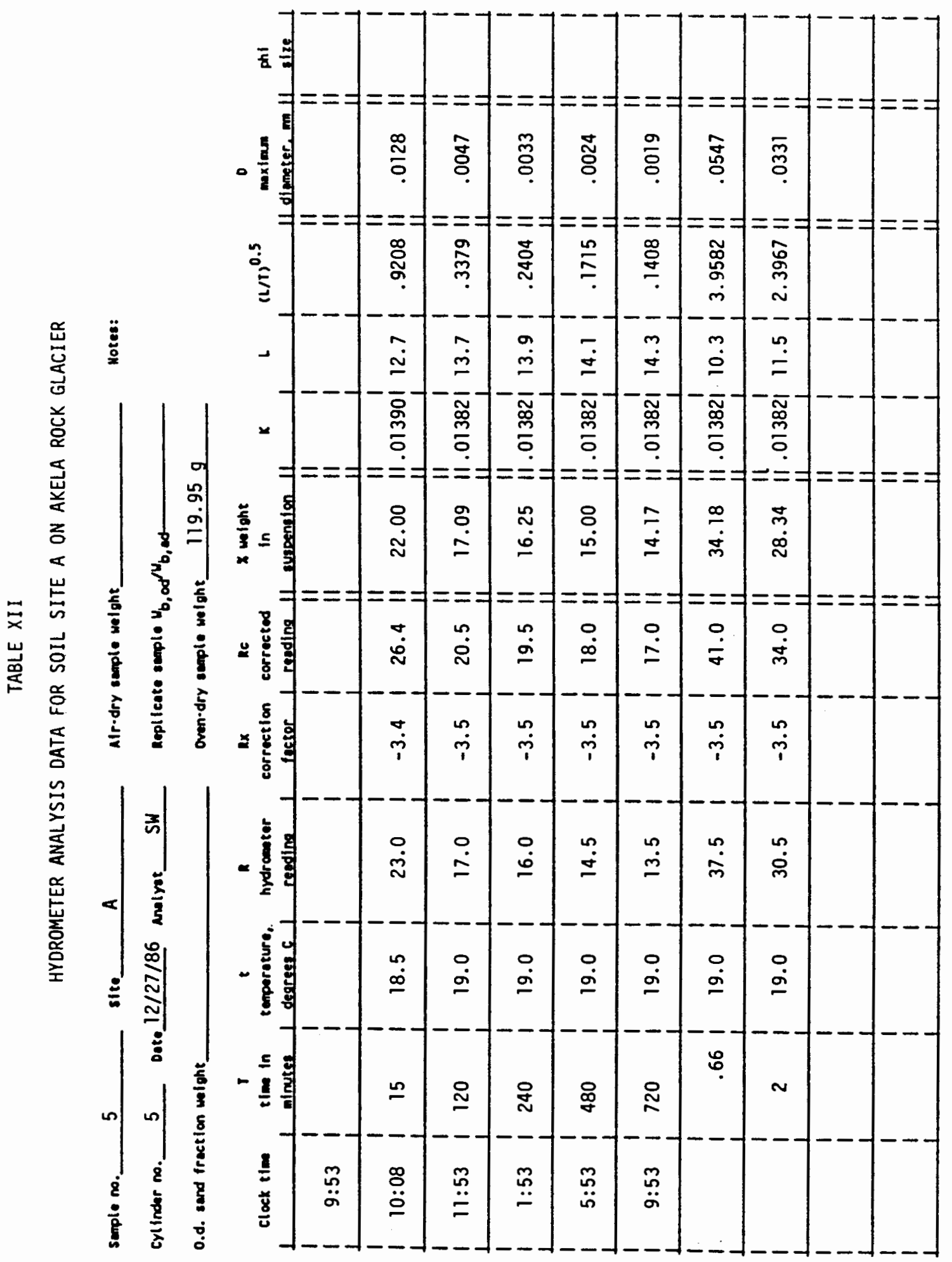




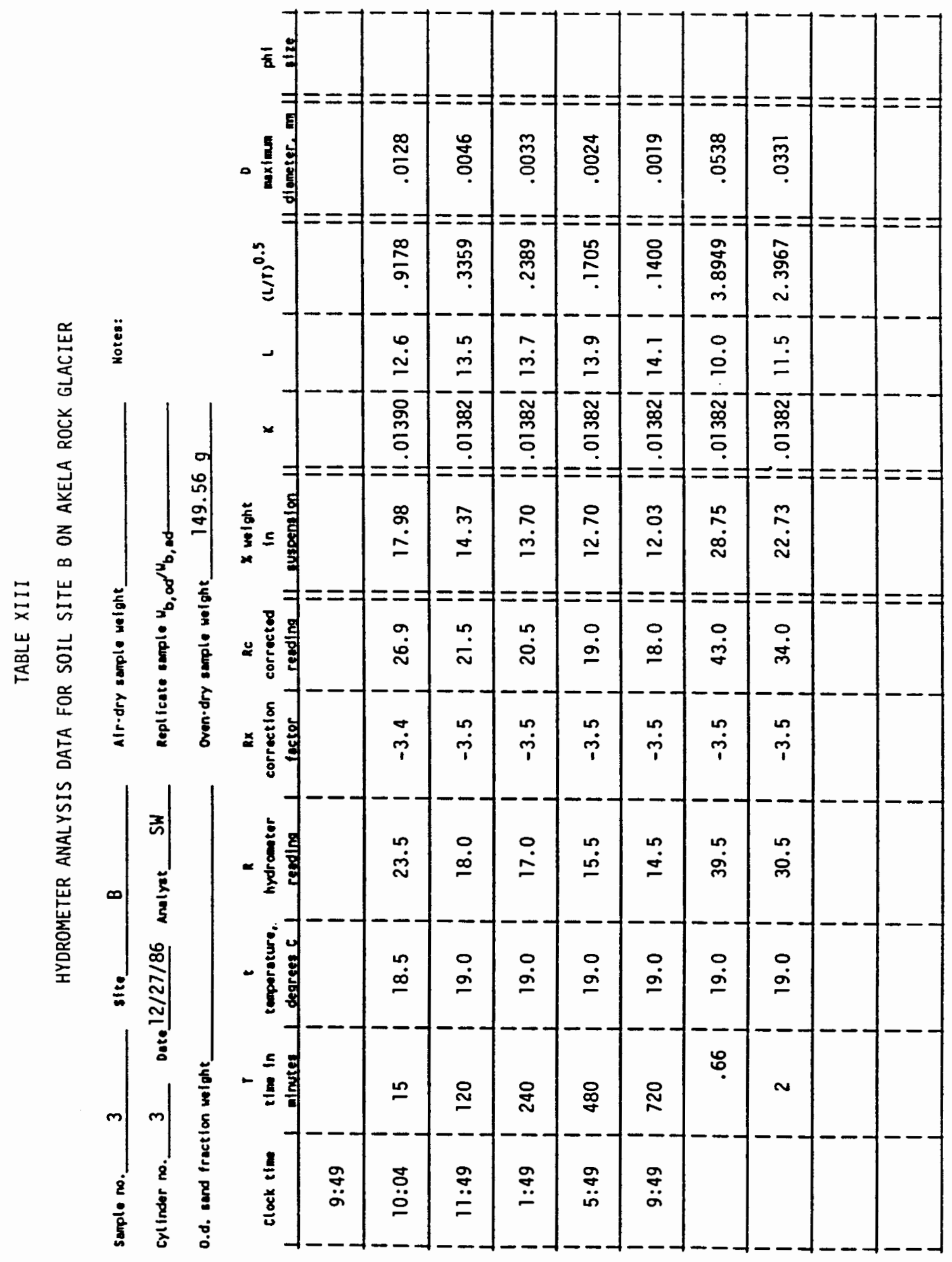




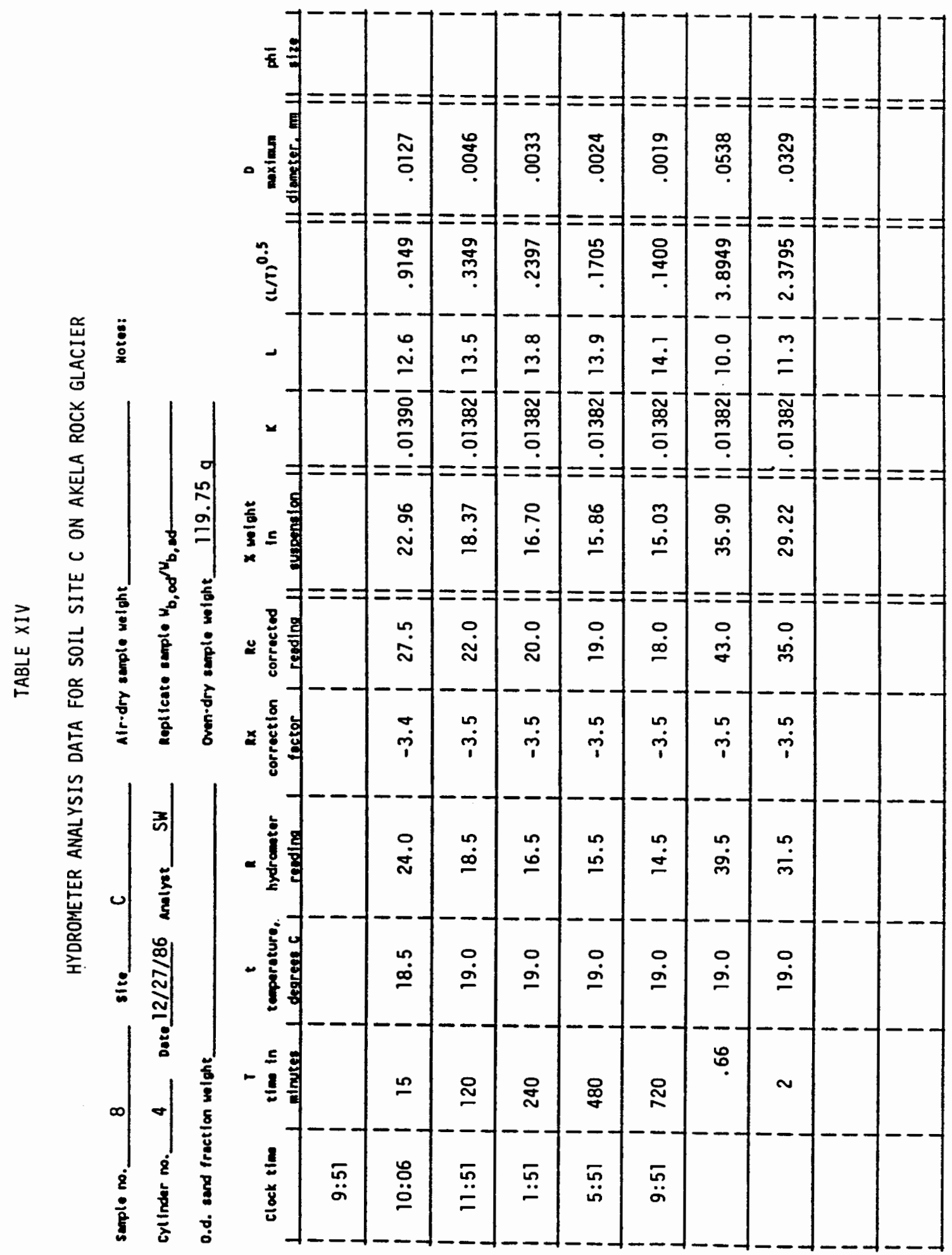




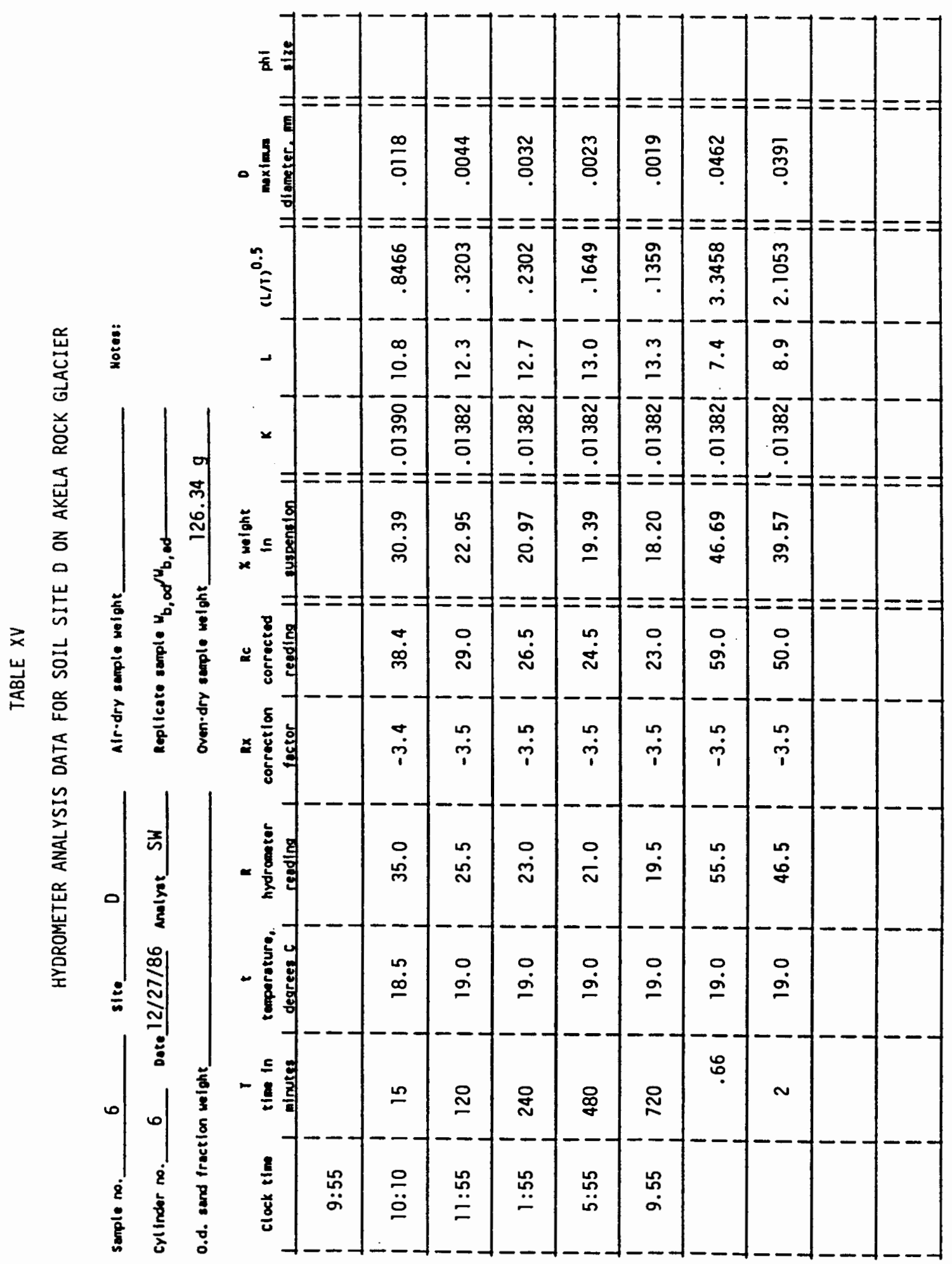




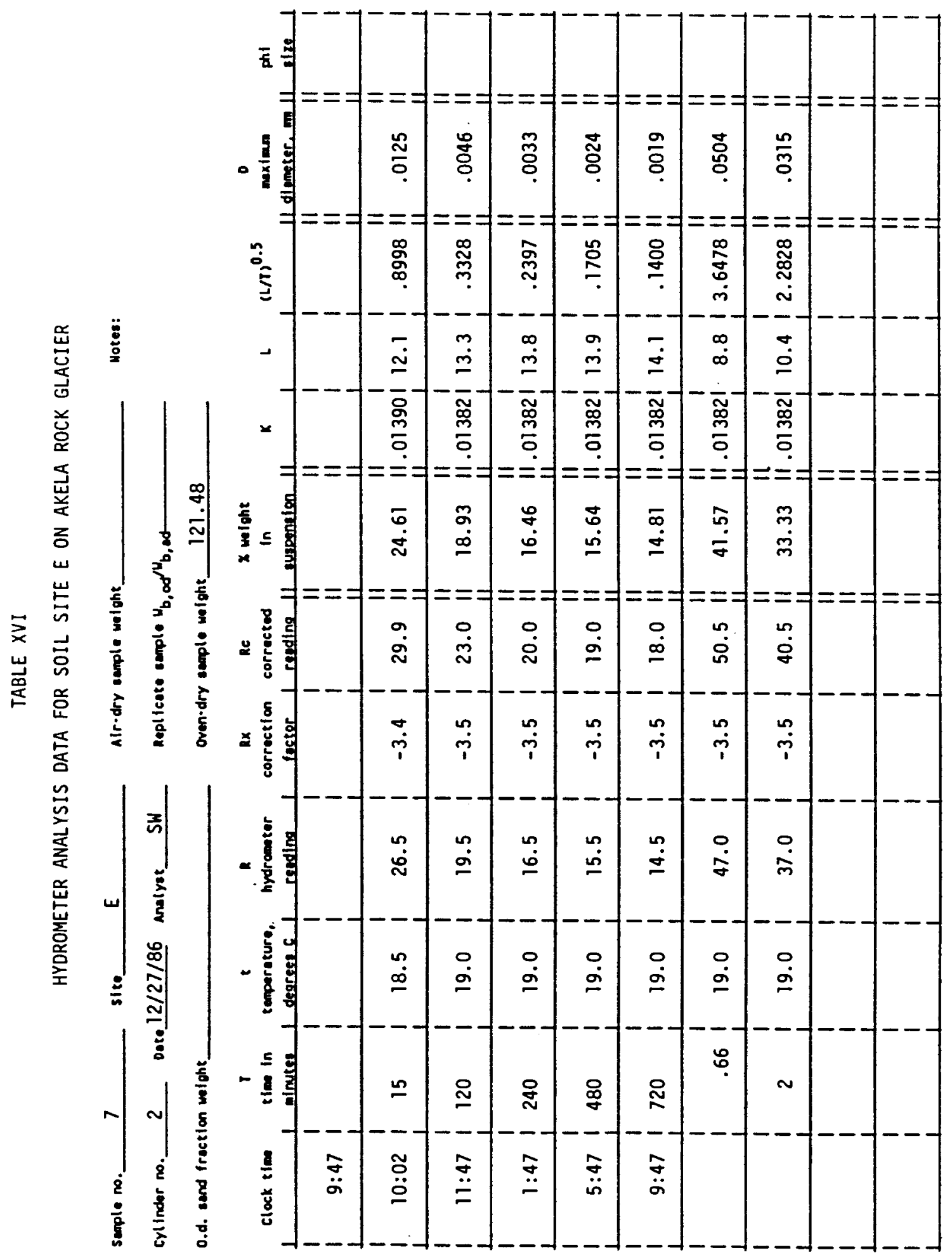




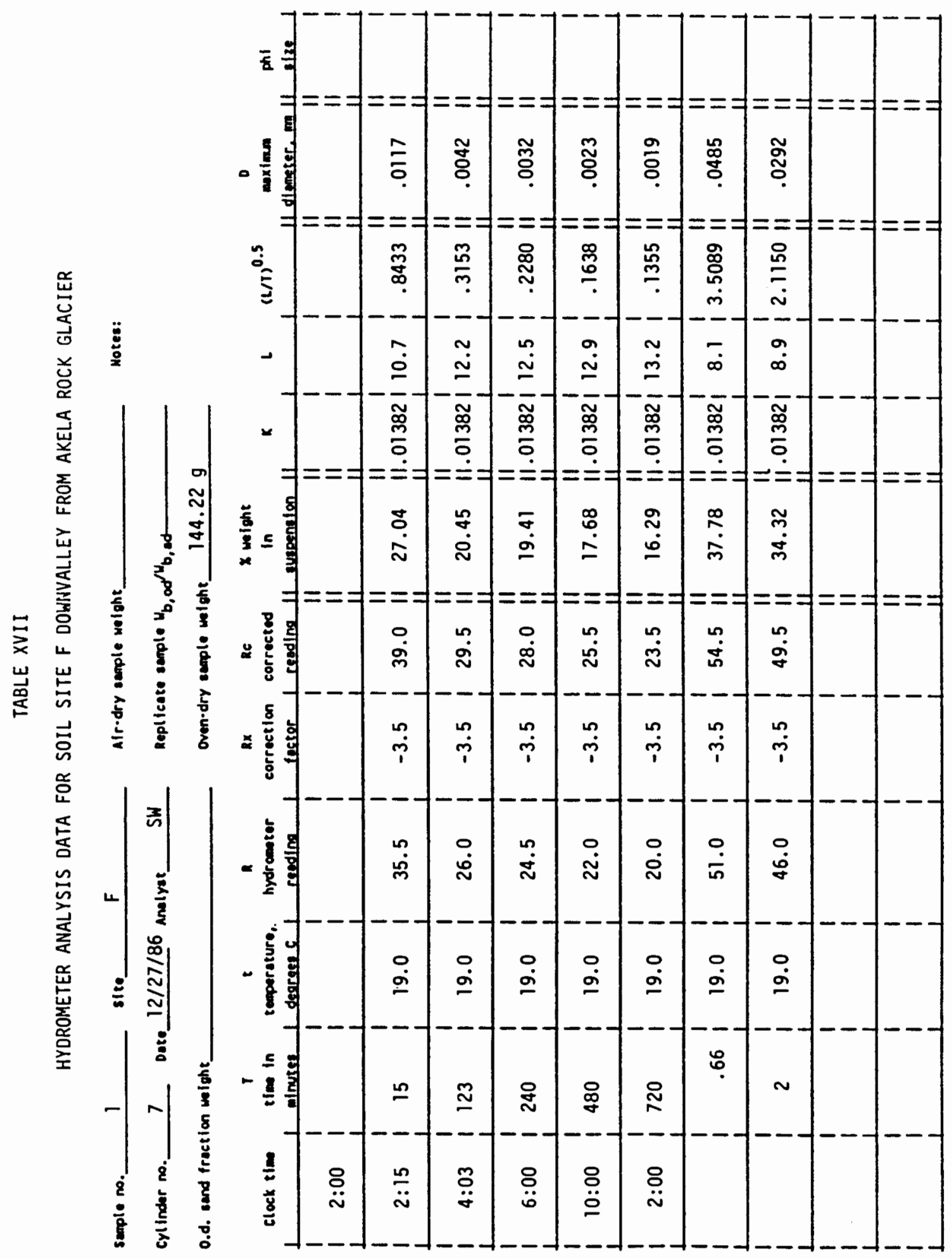




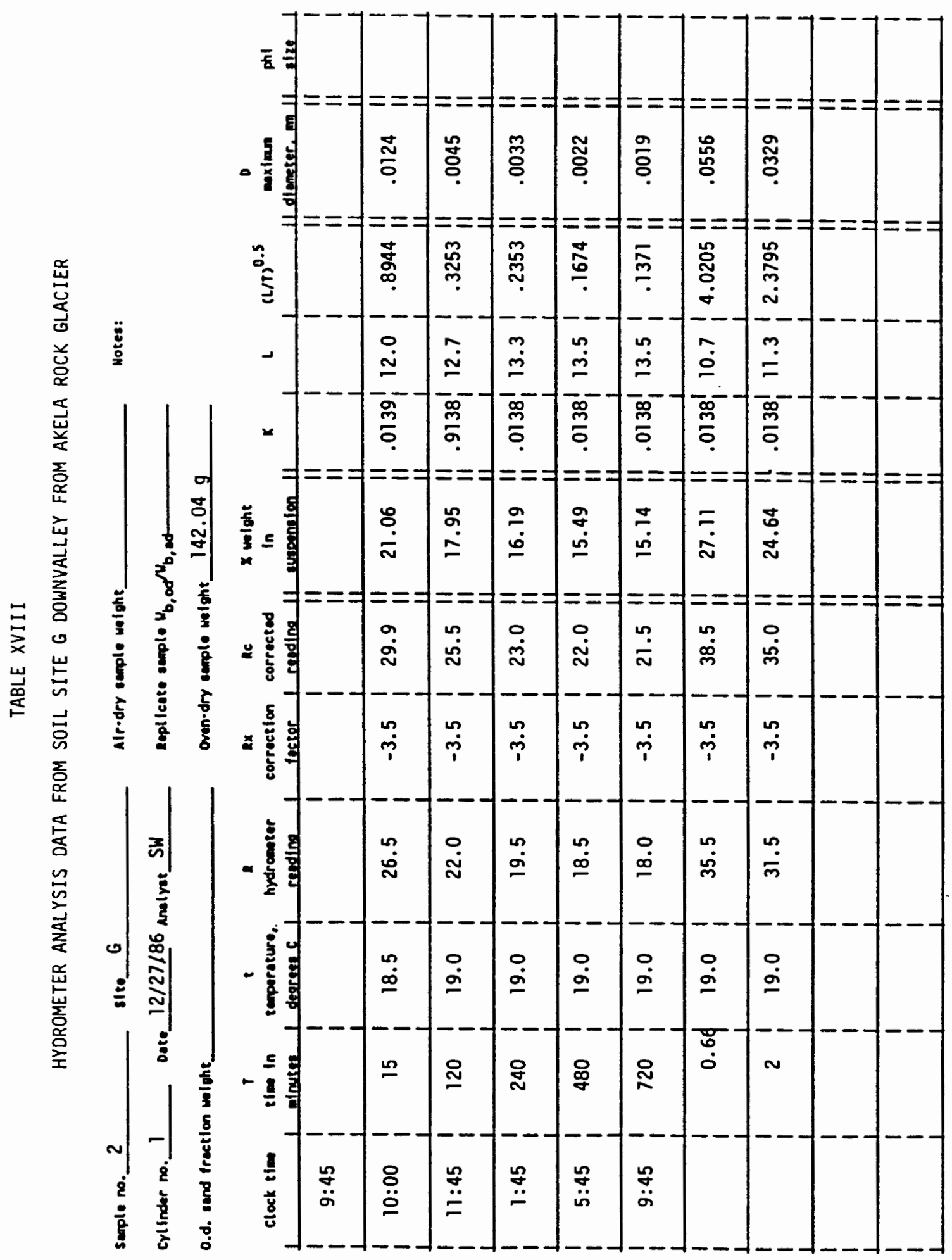

